\title{
SYSTEMATICS AND ECOLOGY OF NEW CALEDONIAN FAVIINAE (COELENTERATA - SCLERACTINIA)
}

by

MAYA WIJSMAN-BEST

Institute of Taxonomic Zoology, University of Amsterdam, The Netherlands

\section{CONTENTS}

Abstract . . . . . . . . . . . . . . . . . . . . . . . . 4

Chapter I. Introduction
A. Scope

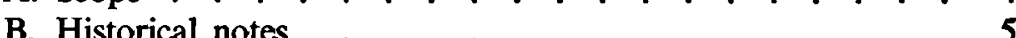

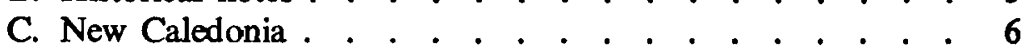

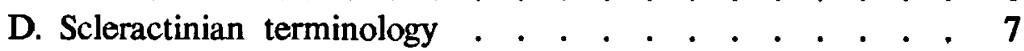
E. Acknowledgments . . . . . . . . . . . . . . 9

Chapter II. Material . . . . . . . . . . . . . . . . 10

Chapter III. Faviinae
A. Classification
B. General ecology . . . . . . . . . . . . . . . 11
C. The 34 New Caledonian species of Faviinae collected . . . 12
D. Discussion of the species . . . . . . . . . . . . 12

Chapter IV. Ecology

A. Discussion on the environmental influences . . . . . . 57

B. Plasticity of the skeleton morphology . . . . . . . . 58

C. The environmental factors influencing coral growth . . . 59

D. Ecotypes in the Faviinae . . . . . . . . . . . . 60

E. The ecological distribution of the species . . . . . . . 61

Chapter V. Discussion

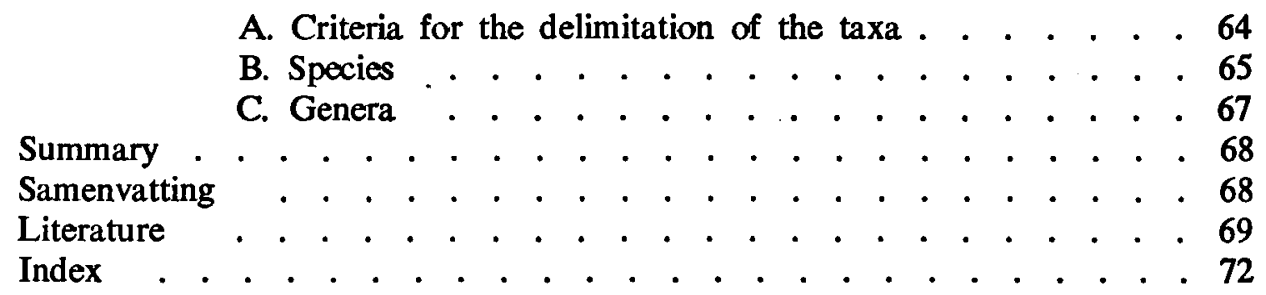

For the abbreviations of the musea cited see under acknowledgments. 


\begin{abstract}
Taxonomic treatment of a large collection of recent corals from New Caledonia belonging to the subfamily Faviinae resulted in the full description of thirty-four species amongst which two are new, while some others are briefly mentioned. A pattern for the subfamily in the influence of environmental factors on growth was found. A comparison between this general pattern and the environment-induced modification of each different form allowed a particular growth form's ecology to be used as a criterion for defining the species to which it should be allocated.
\end{abstract}

\section{CHAPTER I INTRODUCTION}

\section{A. Scope.}

A study of scleractinian corals confronts the scientist with many problems, because this group of sessile marine animals shows an extreme adaptability to various ecological circumstances. Therefore, it is not surprising that the taxonomy of this group is still on a rather basic level. The present study aims to face this challenge by trying to apply the modern concept of the biological species to a discrete group of reef corals.

Early European naturalists identified many different coral specimens brought home from the tropics, all differing from one another in various details. Especially geologists interested in this group of invertebrates that produced so many fossils, named many taxa, the taxonomic status of which is often doubtful.

The problem of determining the limits of the high variability of a coral species is difficult. The only way to investigate this problem is to try to determine with what influence, if any, this variability is correlated. In this thesis I have tried to use the method of Best (1968), studying the changes in appearance of skeleton characters as seen in an ecological gradient. The older museum specimens normally are insufficiently labelled for this purpose. Therefore, the investigation had to start with a field study to obtain material with as much ecological data as possible, together with observations on the habit of the living polyp.

The characters on which coral taxonomy is based had to be examined in different marine environments to see whether they were conservative or adaptive. For instance, is it true that the width of the coenosteum and the number of septa within a calyx, characters used in the determination of species, are not influenced by different ecological circumstances? When they are not, these characters are extremely useful for taxonomic work. However, when a decisive influence of the environment is found either of two procedures may be followed. Either the characters mentioned should be abandoned or one may use them when the rate of their variation can be correlated with some environmental factors, and the morphological deviation therefore be predicted from their habitat.

During my investigations I was forced to attach more importance to the latter procedure, simply because all characters used by former coral systematists are influenced by the environment.

The species belonging to the subfamily of the Faviinae, sensu Wells, 1956, were chosen for my study for the following reasons:

- Specimens of this group are rather common on the coral reefs in the Pacific.

- The Faviinae are of a wide geographical occurrence in the Indo-Pacific, occuring also in the West-Indies.

- Apparently many of the species live in a wide 
range of biotopes and are, therefore, adaptable to various circumstances.

- Many specialists have been working on this group. Even an attempt towards a revision on biological grounds exists (Matthai, 1914).

- The last, technical, reason was that members of this group are relatively easy to identify under water, to collect and to transport.

\section{B. Historical notes.}

It is not necessary to give an exhaustive historical review, since most former coral studies have given a general account of the situation. Before the Linnaean era corals were normally regarded as plants; and not until the beginning of the 18th century did naturalists question this statement. It was Peysonnel, in 1744, who definitely recognized them as animals. A large and heterogeneous group of "Zoophyta" was known at the time of Linnaeus, who in his "Systema naturae" gathered the stony corals into the "Lithophyta", of which most of the species belonged to the genus Madrepora.

During the first hundred years after Linnaeus these terms were used by the authors who described new species of corals, e.g. Forskål, 1775; Ellis \& Solander, 1786; Esper, 1791 to 1797; Lamarck, 1801, 1816; Ehrenberg, 1834. All kinds of hard and soft corals were placed together in large and heterogeneous genera.

The first new efforts to give a broadly based classification for this group of lower marine invertebrates were presented by Dana (1846) in the United States and a decade later by $H$. Milne Edwards \& Haime (1857), in France. While reporting on the corals collected by the U.S. Exploring Expedition (1834 - 1842), Dana described many new species and gave a conveniently arranged system. The contribution of the work of $\mathbf{H}$. Milne Edwards \& Haime is that they rearranged the many coral-like animals into many subdivisions, their "Zoantharia Sclerodermata or Madreporaria" including the stony corals. Several new genera, most of them well-defined, were created and their work forms an epoch in the zoology of corals. In the present paper the term "corals" is used to include only the scleractinian corals.

Now that the zoological classification of corals had become more logical, authors started to synonimize many existing species and to introduce nomenclatorial changes of names (Verrill, 1865, 1872; Klunzinger, 1879; Duncan, 1884). When the zoological collections became large enough to allow the comparison of series, naturalists began to realize the difficulties involved in the great variability of corals. What were the limits of the variation within one species? Quelch (1886) discussed this problem in his report on the reef corals collected by the Challenger expedition: "It is certainly remarkable to notice the great amount of variation to which apparently one and the same species is liable, as is evident where large series of specimens are at hand; and it is probable that such variations are brought about by the influence of one or more of the above conditions" (viz., eight environmental factors).

All later publications of some importance always have had to cope with the problem of variability in stony corals. Bernard (1903) even gave up to use the binominal system. Gardiner (1904) criticizes Bernard and tries to divide the variation shown into three classes: vegetative, continuous, and discontinuous or specific. In 1907 the geologist Vaughan, when identifying the recent Madreporaria of the Hawaiian Islands, was aware of the many mistakes he was doomed to make because "the study of variation is inseparable from experimental physiological investigations, for these are a necessary foundation for the understanding of variation". Under the influence of the ideas of Hugo de Vries he stresses the need to distinguish between genotypically and phenotypically determined variation.

A student of Gardiner, G. Matthai (1914) started a biological approach of the problem "with a view to determining the natural relationships of the genera and species", taking the Astreidae (= Faviidae) as the object of his study. This very thorough and accurate work is still useful, but does not give a final solution for the given problem. In his introduction the author states that all characters hitherto in use do not have any constant value, influenced by the environment as they are. Matthai tried to find conservative characters by examining the anatomy of the living polyps. The merits of this publication will be returned to several times below.

In 1918 Vaughan published an ecological study on the Murray Island coral reef. Some environmental conditions of the reef were observed, including temperature, silt, mechanical effects of moving water, and competition between species. Vaughan attempted to determine which of these factors are relevant to coral growth. Even after this large and important study some later authors continue to work in the elder days' style, only 
describing new forms. The contributions of Faustino (1927), Thiel (1932), Yabe et al. (1936, 1941) and Nemenzo (1959), just to mention several of the students of Pacific Faviinae, are very helpful to coral science in general and have faunistic interest, but do not help us much to understand more about coral taxonomy in the new ecological line of thinking. The latter type of research, however, is pursued by workers such as Umbgrove (1940) and Crossland (1952). Umbgrove gives a detailed account of the different "facies types" in the East Indian localities where he collected, and he often is in doubt as to the specific status of particular specimens.

Crossland concludes in his last study on the corals of the Great Barrier Reef (1952) that the growth form varies so much that many "species" are later found to be the mere products of the effects of environmental influence, for example shallowness, sedimentation or surf.

Modern techniques have made feasible the study of corals in the way that Vaughan proposed as long ago as 1907: "in nature without experiments, in nature by experiments and under artificial conditions in aquaria". It may be noted that for following the effects of a changed environment on the morphology, the colony has ta stay for a long time in an aquarium, which even present day equipment hardly permits. Examples of these physiological/ecological experiments are to be found in the publications of many authors, for example Goreau, Yonge, Stephenson, Roos, Woodhead, and Kawaguti.

A major contribution to coral taxonomy is the modern classification prepared by Vaughan \& Wells (1943). This work covers fossil as well as recent scleractinian corals.

Alloiteau (1952) constructed a classification of the higher taxa of corals, but in the present paper the last system, the revision by Wells (1956) of Vaughan \& Wells, is followed.

\section{New Caledonia.}

New Caledonia is a Franch territory in the southwestern part of the Pacific, the Coral Sea, and belongs to the Melanesian Islands. It is one of the largest islands in the Pacific, being about $500 \mathrm{~km}$ long and $50 \mathrm{~km}$ wide. In the Tertiary (Oligocene) the island was formed and raised to a height of $1650 \mathrm{~m}$. Essentially the country is a long chain of mountains composed of mainly Palaeozoic rocks, surrounded by a narrow belt of raised fossil reefs and later deposits.

Because of this geomorphology large rivers did not form; all over the islands many short ones carry sediments some distance into the sea, making

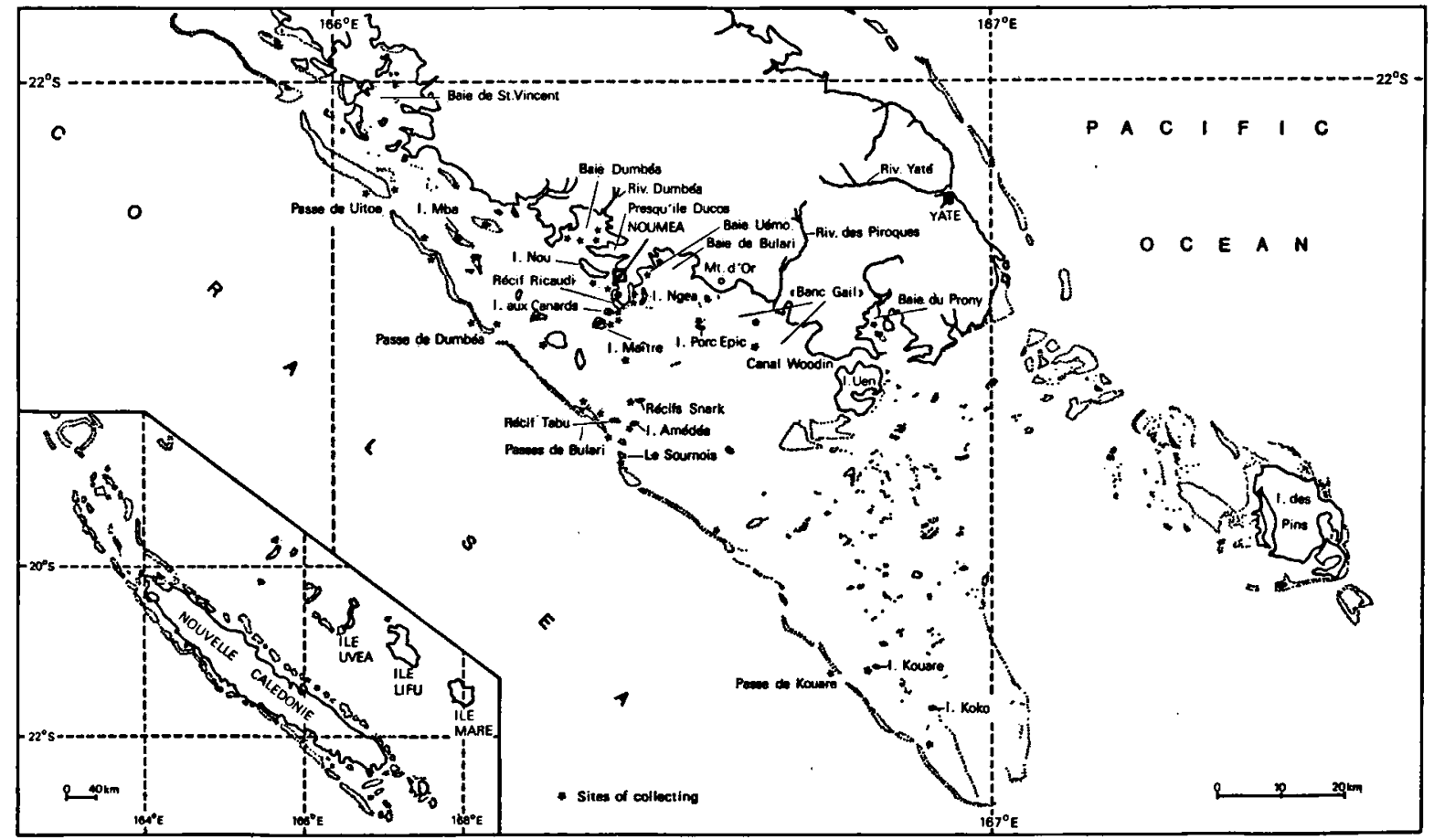

Fig. 1. Map of New Caledonia (left) and the southeastern extremity of the island (right). 
coastal water including the many bays, turbid.

The long island is surrounded by a barrier reef more than $1600 \mathrm{~km}$ long. In the North the reefs extend for more than $800 \mathrm{~km}$ beyond the mainland but in the East, West and South the barrier reef runs parallel with the coast and protects the island from the ocean swell. Between the barrier reef and the fringing reef along the coast there is a lagoon of 10 to $40 \mathrm{~m}$ in depth and up to some kilometers in width. Because the island is situated near the Tropic of Capricorn there is a nearly constant southeastern trade wind all the year round. Under the tropical climate the sea temperature is excellent for coral growth.

Further details of names and geographic features are shown in a map (fig. 1). The southern part of the island is given on a larger scale, because most of the excursions described below were made in this area. Local difficulties (no convenient transport for material, bad roads, etc.) made work in other parts of the island difficult. The area chosen offers plenty of possibilities to examine different coral biotopes. The last point will be elaborated in the next chapter.

New Caledonia was selected as the place for my practical studies, because of several advantages.

First, I could use during the six months of my stay on the island (April-October 1968) the facilities of the small but well equipped private biological station of Dr. R. Catala, where unique possibilities are offered to keep specimens alive for long periods. The aquarium was situated near the shore, so the study of the fringing reef was easy. Second, the local situation is favourable, since a wide choice of different kinds of biotopes is nearby. For example there are barrier reefs, lagoons, fringing reefs, coral islands, small scale atolls in the lagoon, and large protected bays, all offering opportunities for studying the variation of coral species under different environmental conditions. With boats one can make excursions through the lagoon to the barrier reef and back within a day. Third, the capital of New Caledonia, Nouméa, was only $3 \mathrm{~km}$ away. Here is situated the French oceanographic station ORSTOM and the Institut Pasteur, always helpful in making available their facilities. Fourth and last, Dr. J. P. Chevalier of the Institut de Paléontologie in Paris, working as a geologist on the fossil and recent corals of New Caledonia, having introduced me to this choice situation, was willing to let me profit from his stimulating advice.
To date only two faunistic lists of New Caledonian corals have been published. The first was that of Matthai (1923) describing a collection of 91 species of which 14 were Faviinae. The second one was a short note with a list of the genera by Woodhead \& Weber (1969). An elaborate systematic treatise on the recent and fossil corals will be published in the future by Chevalier.

\section{Scleractinian terminology.}

A short explanation of the most important technical terms that are used in the present paper may be convenient.

The scleractinian corals form an order belonging to the Zoantharia, in which the polyps resemble those of the Actiniaria. The Scleractinia differ from the latter by having an external calcareous skeleton (see fig. 2). The skeleton is

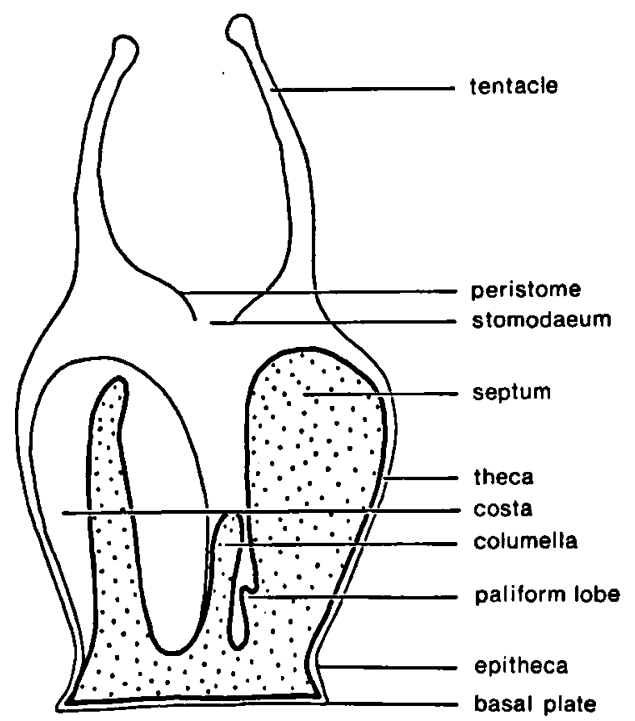

Fig. 2. Scleractinian polyp. (Modified after Wells, 1956).

composed of needles of aragonite which cluster together to form rods called trabeculae. Aragonite is a form of calcium carbonate $\left(\mathrm{CaCO}_{3}\right)$ and is secreted by the calicoblast layer of the polyp. The rods aggregate to form a basal plate from which the vertical partitions (septa) rise.

At the margin of the basal plate a vertical wall (epitheca) is constructed upon which during further growth the wall or theca enclosing the polyp is deposited. The open upper part that is created in this way is called the calyx. When the septa extend beyond the calyx they are termed exsert. On the outside of the theca vertical prolongations of the septa (costae) are formed by the edge zone 
(part of the polyp that lies outside of the wall) and coenosarc (the living tissue in between two corallites in a colony).

One individual is called a corallite and many corallites form a colony or corallum (see fig. 3).

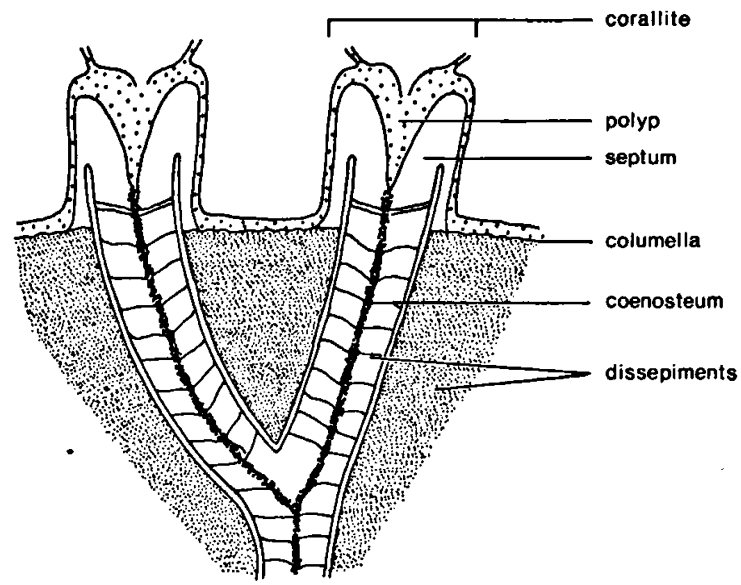

Fig. 3. General relations of polyp and corallum. (Modified after Wells, 1956).

Thin tabular sheets in the spaces between septa and costae are termed dissepiments. Dissepiments excreted at the outer or inner part of the theca are called exotheca and endotheca, respectively; skeleton deposits between two corallites we term coenosteum. Inside each corallite a central skeletal structure, the columella, is formed by the inner ends of the septa. Sometimes between septa and columella rods or lamellae are present, called pali; when these vertical structures are offsets from the inner edges of the septa, we call them paliform lobes. Small rods that connect one septum with the other are called synapticulae.

The polyp (see fig. 2) is fixed on its basal plate and has at the upper end a mouth surrounded by the peristome which is bounded by tentacles. There is a connection between the mouth and the interior gastrovascular cavity called the stomodaeum. The cavity is divided by the vertical radial mesenteries into several compartments (a multiple of six). The mesenteries excrete the septa.

The reproduction of scleractinian corals may be sexual, the planula larva forming a new corallite and colony, or asexual. Asexual reproduction is of much importance for the various forms of a coral colony, because there are several ways of asexual reproduction: (1) intratentacular budding ("fission"), (2) extratentacular budding ("budding"), and (3) transverse division. In the first case the new individual arises within the tentacular ring and in the second case outside the tentacular ring. These processes can be brought about in various ways. After intratentacular budding there are two or three stomodaea within one tentacular ring. When this is a permanent condition, we call such a corallite dicentric or tricentric; but when the new individuals are separated from the old one, all of them are monocentric. In the polystomodaeal condition, the corallum is called polycentric. A corallum which reproduces asexually by extratentacular budding can only have monocentric corallites. Transverse division is a phenomenon observed only in a few corals, and never in the Faviinae.

As already stated the form of the coral colony depends greatly on the mode of colony formation. In fig. 4 a synopsis is given of the different

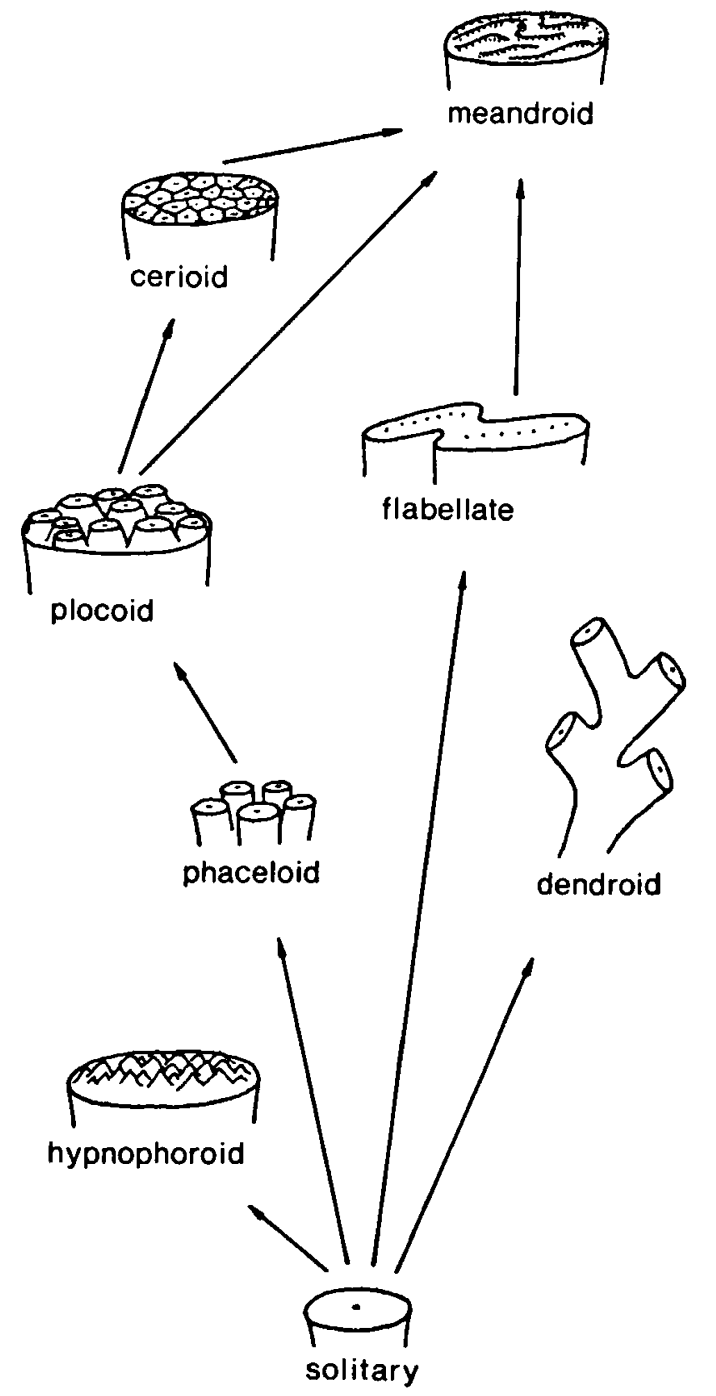

Fig. 4. Morphogenetic trends in colony formation. (Modified after Wells, 1956). 
colony forms. Usually a colony originates from one corallite, but it is also possible that a number of planulae of the same species settle together and form one colony.

The corallum can spread over the surface (encrusting) or form branches (dendroid). The corallum where the new buds remain on the same level as the old ones, growing parallel and laterally free upwards, is called phaceloid, or, when they are not laterally free but united to each other by costae or dissepiments, plocoid. Cerioid denotes the condition in which the corallites are monocentric and only separated from the other ones by fused walls. When the corallites form linear series (polycentric) the colony is called meandroid. Meandroid coralla with a single continuous slightly contorted or straight, laterally free linear series are termed flabellate. Hydnophoroid colonies have the corallite centres arranged around protuberant monticules.

\section{E. Acknowledgments.}

It is a pleasure to take the opportunity to express my gratitude to the many people I feel indebted to for the success of my stay in New Caledonia.

The opportunity to live and to work for half a year in the well situated private institute for marine biology of Dr. R. Catala and Mme Catala-Stucki, the "Aquarium de Nouméa", was the prime factor in this result, in addition to being an exceptional chance for me and a most instructive event. I thank them very much and want to extend my gratitude to the staff of the Aquarium, who have helped me with the not always easy and pleasant work of collecting and cleaning my coral specimens.

Next I should mention several helpful contacts in Nouméa. I am obliged to Dr. M. A. Tonnier, director of the Office de la Recherche Scientifique et Technique Outre Mer (ORSTOM), and his collaborators, Mr. P. Rual, Mr. J. Launay, and Mr. A. Michel. They have helped me many times in practical requirements and, particularly in taking me on their excursions to various parts of the lagoon and to remote bays, over land and over sea. Mr. A. Michel was kind enough to permit me to make use for this paper of unpublished ecological observations he has made. The South Pacific Commission, kindly allowing me space in their building for some time, and the Institute Pasteur, where I could make use of the essential prerequisites for making histological preparations have a full title to my gratitude.

Snecial thanks are due to Mr. B. Conseil and Mr. L. Nedgar, because the hospitality on their vessel and their enthousiastic aid in diving, as well as their help in the actual collecting of the corals, were the main reasons why it was possible to obtain so many data in so short a period. That I could join the weekly Saturday afternoon exercises of the local Diving Club, somewhere inside or outside the barrier reef, was another opportunity that I have gladly profited from. My sincere thanks to all people mentioned.
In spite of the many pessimistic suppositions in the literature that several type specimens were lost, I have traced about $75 \%$ of the types of the named species in the Faviinae. No material was consulted of the Institute of Geology and Palaeontology, Tohoku Imperial University, Sendai, Japan (TIU) and of the University of the Philippines, Manila (UP). I feel indebted for the loan of sorted out material under their custody to my colleagues Dr. D. Kühlmann, Museum für Naturkunde der Humboldt Universität (ZMB), Dr. K. W. Petersen, Universitetets Zoologiske Museum, Copenhagen (UZMC), Dr. W. D. Hartman, Yale Peabody Museum, New Haven (YPM), Dr. J. W. H. Lawson, Department of Zoology, the University of Glasgow (Gl). Special mention for being helpful hosts as well is due to the following curators: Dr. J. P. Chevalier, Muséum National d'Histoire Naturelle, Paris (MNHN), Dr. P. Cornelius, British Museum (Natural History), London (BMNH), Dr. D. Pawson, National Museum of Natural History, Washington D.C. (USNM), Dr. H. Levi, Museum of Comparative Zoology, Harvard University, Cambridge (Mass.) (MCZ), Dr. H. Möller, Zoologisches Institut, Erlangen (EZI), Mr. S. Fuller, Academy of Natural Sciences, Philadelphia (PAS), and Dr. W. Vervoort, Rijksmuseum van Natuurlijke Historie, Leiden (RMNH). I received some useful information of Dr. G. Scheer (Darmstadt). To all of them I express my sincere thanks.

A great stimulus to the undertaking of the present work was Professor J. W. Wells, always willing to answer letters with questions and a very generous host in his pleasant home on Lake Ontario. I have much appreciated the interest with which Professor H. Engel (formerly Zoological Museum Amsterdam (ZMA)) and Professor $P$. Drach have been following my progress in the study of this group of animals and I hope that Professor Engel will find back several of the ideas he used to foster in his students.

I want to express my gratitude to Professor Dr. J. $\mathbf{H}$. Stock, for his accurate criticisms and the dynamic way in which he guided the preparation of the manuscript. I feel much indebted to Professor Dr. H. Boschma who was so kind to read the whole manuscript and let me profit of his thorough knowledge of the literature. The help of Dr. P. Cornelius by his critical reading of the English text is gratefully acknowledged.

I am sure that without the help and initiative of Dr. J. P. Chevalier this work could not have taken place in New Caledonia. I wish to express my gratitude to him not only for his introduction into the possibilities of the island, but also for most valuable discussions and exchange of as yet unpublished observations and descriptions.

Finally I am thankful to my husband, Dr. H. J. W. Wijsman, for his fundamental criticism and spurring enthousiasm, his interest in and translations of many historical notes and his stimulating help in tracing type material.

The fieldwork of the project, as well as the visit to the American musea was financed by the Netherlands Foundation for the Advancement of Tropical Research (WOTRO). A grant of the Maatschappij voor Wetenschappelijk onderzoek in de tropen (Treub-maatschappij) enabled the publication of this paper. 


\section{CHAPTER II MATERIAL}

About 950 coral colonies were collected from various depths and from various biotopes. Most of the Pacific hermatypic genera were found. There are 51 hermatypic genera, including 7 not recorded by Woodhead \& Weber, 1969. This collection was gathered by SCUBA diving on 40 trips, some of them including two or more dives. The localities of these dives are plotted in fig. 1. Roughly I have divided the reef area in seven more or less arbitrary biotopes (fig. 5). For various practical reasons it was not possible to carry out
About $60 \%$ of my New Caledonian collection belongs to the Faviidae, and of these about $70 \%$ are Faviinae. The New Caledonia -collection on which the results are based comprises 380 specimens. The genus Favia Oken, 1815 is best represented, for it was my original purpose to study the species of this genus alone; however, later on it came out that it is hardly possible to study them without considering the other closely allied genera.

The coral colonies were put in bags, one for each site examined, specimens from a peculiar micro-biotope or fragile specimens being kept

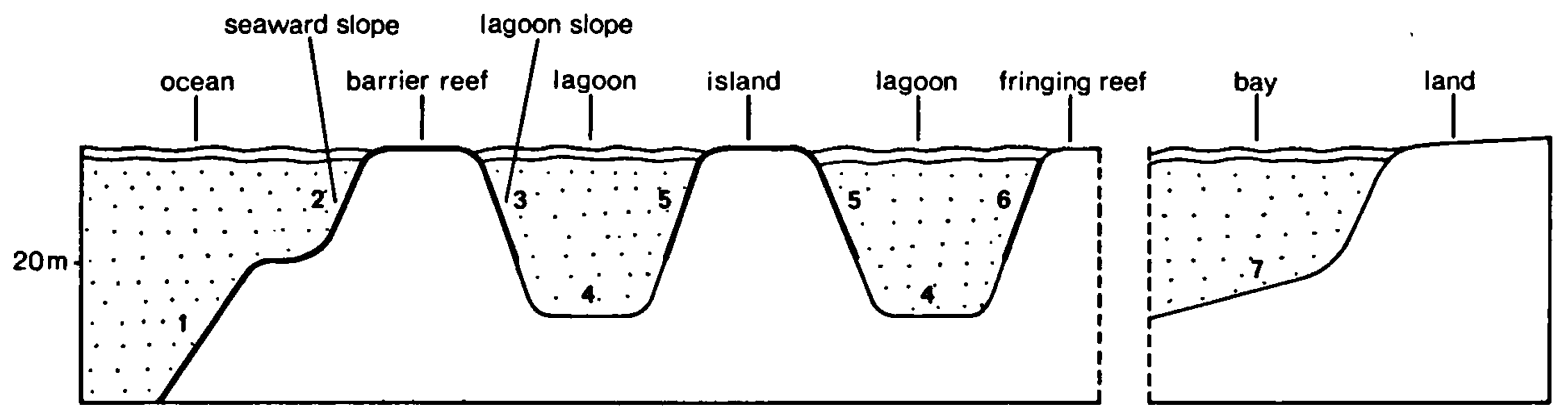

Fig. 5. A schematic cross section of New Caledonia coral biotopes.

the same number of observations in all seven biotopes. Going out to the barrier reef was not always feasible. Now it was the weather that prevented an excursion, then a suitable boat was not at hand; moreover a dive below $30 \mathrm{~m}$ outside the barrier reef can never be a long one and several dives in succession are not allowed because of safety measures.

Collecting in the bays was mostly done together with some scientists of ORSTOM. Work on the nearby fringing reef in contrast was easy enough. The division of the 40 excursions (including 64 sites) over the seven biotopes was as follows:

$$
\begin{array}{ccc}
\text { biotope } & 1-7 & \text { excursions } \\
" & 2-8 & " \\
" & 3-7 & " \\
" & 4-13 & " \\
" & 5-4 & " \\
" & 6-12 & " \\
" & 7-13 & "
\end{array}
$$

Field characters of the coral genera are not easy to distinguish until field experience has been gained and observations of living specimens can be correlated with the skeleton structure. For this reason Faviidae were collected more successfully towards the end of the study period than at the beginning. separately. Sometimes notes were made under water but usually a small report was written in the boat after every dive. In the Aquarium the corals were placed in sea water after having a numbered plastic label attached. A small laboratory connected with the Aquarium was put at my disposal during my stay. It had a working table, two big experimental tanks and six smaller ones. All tanks were directly supplied with offshore sea water, in an open system. This system was good enough to keep the very sensitive stony corals in good condition as long as was needed.

All polyps were described. The more important specimens were photographed (colour slides) and some were used for making histological preparations. Parts of the animal were preserved with various experimental methods, sometimes preceded by decalcification. Because there were no facilities in the laboratory for histological work, this was done in the Institut Pasteur (Nouméa) with the help of Dr. Chenier. The results of this work will be published in the future.

After the data had been collected, the animals were killed by putting them in fresh water for about two days. After most of the polyp tissue was squirted away, the skeletons were dried in the sun, having the plastic label still attached. 
In addition to my own material, with as many ecological data as needed for my taxonomic study, the mostly still unidentified Pacific Faviinae present in the Zoological Museum of Amsterdam were used for this study, including the material from the Siboga expedition. The Faviinae of other museums where I have been working have been used for comparison as far as time allowed.

\section{CHAPTER III FAVIINAE}

\section{A. Classification.}

Wells (1956) divided the scleractinian corals into 5 suborders: Astrocoeniina, Fungiina, Dendrophylliina, Faviina, and Caryophylliina.

One of the ten families of the suborder Faviina Vaughan \& Wells, 1943, is the family Faviidae Gregory, 1900. This group of reef corals includes both solitary and colonial species. In all of them paliform lobes are present, the septa are mostly exsert and the columella is trabecular or laminar. The colony formation may be extra- or intratentacular.

On the basis of this last character the subfamilies Faviinae Gregory, 1900 and Montastreinae Vaughan \& Wells, 1943, are separated. The subdivision is rather artificial and, therefore, not accepted by all authors. Although the distinction is not always clear, the separation of the two subfamilies is practical, and it is used here with some alterations.

In the Faviinae the colonies are formed by intratentacular (rarely extratentacular) budding while in the Montastreinae extratentacular budding is dominant. Recent Pacific genera belonging to the Faviinae mentioned by Wells are:

Caulastrea Dana, 1846

Bikiniastrea Wells, 1954

Barabattoia Yabe \& Sugiyama, 1941

Plesiastrea H. Milne Edwards \& Haime, 1848

Favia Oken, 1815

Favites Link, 1807

Oulophyllia H. Milne Edwards \& Haime, 1848

Goniastrea H. Milne Edwards \& Haime, 1848

Platygyra Ehrenberg, 1834

Leptoria H. Milne Edwards \& Haime, 1848

Hydnophora Fischer de Waldheim, 1807.

Plesiastrea is excluded from the list since the extratentacular budding is dominant in this group. There are 147 identifiable nominal species of $\mathrm{Fa}$ viinae in the literature. Many of these names have already been synonymized by former authors. In the collection from New Caledonia 34 species are recognized, belonging to 8 genera.

\section{B. General ecology.}

Most hermatypic corals live within $50 \mathrm{~m}$ of the surface, although they may be present down to $90 \mathrm{~m}$. The most luxuriant growth is found between $1 \mathrm{~m}$ and $20 \mathrm{~m}$. The main environmental factors that control reef growth can be summarized as follows (Wells, 1957; Stoddart, 1969):

(a) Light. The symbiotic zooxanthellae living in the polyp tissue of hermatypic corals need light. They are of much importance for the growth of the host, and the growth rate of the coral depends, indirectly, on the amount of sunlight.

(b) Temperature. Experiments showed that corals do not grow when the annual minimum temperature is below $18^{\circ} \mathrm{C}$. The temperature range of $25^{\circ}$ to $29^{\circ} \mathrm{C}$ is optimal for coral growth.

(c) Salinity. The salinity tolerance has been shown to lie between $27 \%$ and $40 \%$. The optimum lies at the normal ocean salinity of $36 \%$.

(d) Water turbulence. Apart from its mechanical influence, water movement controls coral growth by providing food and oxygen and removing waste products.

(e) Sedimentation. This is a limiting factor for coral growth, although it is known that many corals can tolerate a certain amount of sedimentation, branching corals being more tolerant than massive ones.

When we consider what are main factors depth seems to play a major role, but this is only because in deeper water there is a decrease of light intensity, temperature and wave exposure.

Together these factors account for the variation in the habitat. In fig. 5 a schematic cross section of New Caledonian reefs is given, in which our seven arbitrarily chosen biotopes are indicated: (1) Outside the barrier reef, below $20 \mathrm{~m}$. Light intensity is low, wave action is reduced and the temperature is slightly lower than at the surface. (2) Outside the barrier reef below the tidal zone down to $20 \mathrm{~m}$. The light intensity is optimal for coral growth. The ocean breakers give a maximum of water movement on the reef crest.

(3) Inside the barrier reef ( 0 to about $15 \mathrm{~m}$ depth). This area is sheltered so there is less water movement and in the quiet water the light intensity is optimal.

(4) Lagoon floor consisting of sand (about 15 to $\max .30 \mathrm{~m}$ ). There is enough light for coral growth 
and a periodical water movement, caused by tidal currents. There is some sedimentation; coral growth is scarce.

(5) The reefs surrounding the lagoon islands $(0$ to about $15 \mathrm{~m}$ ) are sheltered by the barrier reef. The light decreases with depth; there is little sedimentation.

(6) Fringing reefs ( 0 to about $15 \mathrm{~m}$ ) are sheltered by the barrier reef. The light decreases with depth and the sedimentation and salinity are related to the presence of rivers.

(7) In bays with a floor consisting of sand and mud (to a depth of about $30 \mathrm{~m}$ ). There is little water movement and the salinity and sedimentation are related to the presence of rivers. Turbidity causes much of the light to be absorbed.

C. The 34 New Caledonian species of Faviinae collected.

1. Favia favus (Forskål, 1775)

2. Favia speciosa (Dana, 1846)

3. Favia pallida (Dana, 1846)

4. Favia matthai Vaughan, 1918

5. Favia rotumana (Gardiner, 1899)

6. Favia amicorum (H. Milne Edwards \& Haime, 1848)

7. Favia valenciennesi (H. Milne Edwards \& Haime, 1857)

8. Favia stelligera (Dana, 1846)

9. Favia laxa (Klunzinger, 1879)

10. Favites pentagona (Esper, 1794)

11. Favites melicerum (Ehrenberg, 1834)

12. Favites rufa nov. spec.

13. Favites chinensis (Verrill, 1866)

14. Favites palauensis (Yabe \& Sugiyama, 1936)

15. Favites acuticollis Ortmann, 1899

16. Favites abdita (Ellis \& Solander, 1786)

17. Favites virens (Dana, 1846)

18. Favites flexuosa (Dana, 1846)

19. Goniastrea retiformis (Lamarck, 1816)

20. Goniastrea spectabilis (Verrill, 1872)

21. Goniastrea favulus (Dana, 1846)

22. Goniastrea pectinata (Ehrenberg, 1834)

23. Goniastrea australensis (H. Milne Edwards \& Haime, 1857)

24. Platygyra lamellina Ehrenberg, 1834

25. Platygyra daedalea (Ellis \& Solander)

26. Platygyra sinensis (H. Milne Edwards \& Haime, 1849)

27. Oulophyllia crispa (Lamarck, 1816)

28. Leptoria phrygia (Ellis \& Solander, 1786)

29. Hydnophora exesa (Pallas, 1766)

30. Hydnophora microconos (Lamarck, 1816)
31. Hydnophora rigida (Dana, 1846)

32. Caulastrea echinulata (H. Milne Edwards \& Haime, 1849)

33. Caulastrea furcata Dana, 1846

34. Caulastrea curvata nov. spec.

D. Discussion of the species.

All important taxonomic publications of this century on the Indo-Pacific Faviinae have been consulted for the species discussed. Works referred to are: Gardiner, 1899; Verrill, 1902; Gardiner, 1904; Vaughan, 1907; Matthai, 1914; Vaughan, 1918; Matthai, 1924; Hoffmeister, 1925; Faustino, 1927; Matthai, 1928; Yabe, Sugiyama \& Eguchi, 1936; Umbgrove, 1939; Umbgrove, 1940; Yabe, Sugiyama \& Eguchi, 1941; Crossland, 1952; Wells, 1954; Nemenzo, 1959.

The various specific names used show a great variation in the interpretation of the various species. Every author has new definitions for some species, and type specimens have not always been consulted. Therefore, comments on colonies from other collections are only made on those of which either the description and illustration were sufficient or of which the specimen could be examined; especially when in addition environmental data are known.

\section{Favia Oken, 1815.}

Type species. - Madrepora fragum Esper, 1795, by subsequent designation: H. Milne Edwards \& Haime, 1857: 439.

Diagnosis of the genus (after Wells, 1954). Plocoid, massive, foliaceous or incrusting colonies formed by mono- to tristomodaeal budding, corallites permanently monocentric. Vesicular endoand exothecal dissepiments. Columella trabecular, spongy.

The following species are here discussed:

- Favia favus (Forskål, 1775)

Common; calices relatively large and round, septa numerous and of even height, not very exsert; polyp light brownish-violet, sometimes with a greenish stomodaeum.

- Favia speciosa (Dana, 1846)

Common; calices round, septa of even height, hardly exsert, paliform lobes not well developed; polyp brownish-yellow, sometimes with a greenish stomodaeum.

- Favia pallida (Dana, 1846)

Common; calices often capricious of form, septa 
of uneven height, primary ones exsert, paliform lobes well developed; polyp brownish-grey, sometimes with a purple bloom.

\section{- Favia matthai Vaughan, 1918}

Rare; calices round, sometimes extratentacular budding, primary septa up to $2 \mathrm{~mm}$ exsert, theca not well developed; polyp reddish-violet, sometimes with a greenish-blue edge.

\section{- Favia rotumana (Gardiner, 1899)}

Rare; corallites very close to each other, thecae thin, hardly developed, septa strongly exsert up to $2.5 \mathrm{~mm}$, costae not always present; polyp greyishgreen, sometimes with light green stomodaeum.

- Favia amicorum (H. Milne Edwards \& Haime, 1848)

Rather common, especially in lagoons; calices round, thecae well developed up to $1.5 \mathrm{~cm}$, budding sometimes extratentacular, septa of even height, not exsert; polyp yellowish-brown with a light green stomodaeum.

- Favia valenciennesi (H. Milne Edwards \& Haime, 1857)

Common; calices round, close to each other, thecae well developed (a deep groove between the calices is the result), sometimes extratentacular budding, septa of even height; polyp brownishgrey with greenish stomodaeum.

\section{- Favia stelligera (Dana, 1846)}

Rare; form of the colony sometimes hillocky, the corallites small, diameter about $3 \mathrm{~mm}$, septa and well developed paliform rods not numerous, thecae hardly developed, septa about $1 \mathrm{~mm}$ exsert; polyp light brown.

\section{- Favia laxa (Klunzinger, 1879)}

Rare; form of the colony sometimes hillocky, corallites small, average diameter $5 \mathrm{~mm}$, sometimes extratentacular budding, walls thin, septa regular, average number 21 , styliform rods around small columella, costae and intercostal ridges well developed; polyp light brown.

Favia favus (Forskål, 1775). Pl. II figs. 1, 2.

Madrepora favus Forskål, 1775: 332, lectotype UZMC no. 31.

Synonyms. -1 )

Madrepora cavernosa Forskål, 1775. UZMC No. 1.

*Madrepora denticulata Ellis \& Solander, 1786. G1, ?

1) An asterisk (*) proceding a taxon means that no type specimens have been traced.
Parastrea affinis H. Milne Edwards \& Haime, 1850. MNHM.

* Parastrea rousseaui H. Milne Edwards \& Haime, 1850. MNHM, ?

Parastrea savignyi H. Milne Edwards \& Haime, 1850, MNHM.

Parastrea jacquinoti H. Milne Edwards \& Haime, 1857. MNHM.

Parastrea geoffroyi H. Milne Edwards \& Haime, 1857. MNHM.

Parastrea aspera H. Milne Edwards \& Haime, 1857. MNHM.

Favia tubilifera Klunzinger, 1879. ZMB No. 2169.

Favia ehrenbergi (var. microstoma) Klunzinger, 1879. ZMB No. 2170.

Favia danae Verrill, 1872. USNM No. 32.

Orbicella borradailei Gardiner, 1904. BMNH No. 27.5.4.14.

Favia favus var. crassidens Crossland, 1952. BMNH No. 1934.5.14.98.

Material. -

New Caledonia collection ZMA 28 colonies: Biotope 1 - Coel. 5692

$\quad 2$ - Coel. $5693-5694$

" 4 - Coel. $5695-5696-5697$

" $5-$ Coel. $5698-5699$

" 6 - Coel. $5700-5701-5702(2 \times)$

" 7 - Coel. $5703-5704-5705-5706-$

$5707-5708-5709-5710-$

$5711-5712-5713-5714-$

$5715-5716-5717-5718$.

Other collections:

ZMA Coel. $315 \quad$ Red Sea (unspecified)

Coel. 316 Japan

Coel. 1733 Nosy Bé (Madagascar)

Coel. 5602 Mauritius

Coel. $5753 \quad$ Moluccas

Coel. $5754 \quad$ Aru Islands

Coel. 5755, 5756 Roti Island (Lesser Sunda

Islands)

RMNH No. 375

"Indian Ocean"

(unspecified)

No. 378

Djeddah (Red Sea)

BMNH No. 88.10.25.12 Mauritius

No. 27.5.12.137 Red Sea (unspecified)

Characters. -

Corallum: The colony is plocoid, spherical, flat or encrusting. The calices are more or less round, average diameter $12 \mathrm{~mm}$; the septa are numerous, average number 30 (with a maximum of 41 and a minimum of 24), they are mostly even in height and not exsert. They descend gently into the calyx and are not strongly dentated, sometimes forming paliform lobes; at the outside of the theca wall the costae, being regularly dentate, are strongly developed and intercostal ridges are sometimes to be seen. These ribs continue on the coenosteum, which is of various width. The co- 
lumella consists of twisted septal teeth.

Polyp: In general the colour of the living animal is brownish-violet, with a greenish stomodaeum.

Variability of the characters in the different biotopes. -

As a result of the diversity of environments in which a coral colony develops, differences in morphology can be observed. The most important factor which brings about these changes is depth, to which light intensity and water action are related.

At the surface there is strong water movement and the light is maximal. Colonies that are found near the surface (biotopes 2, 3, 5 and 6) generally have a deep calyx, more and stronger teeth, a not so well developed paliform structure and corallites arranged close to each other especially on the upper side of the corallum. In water below 15 to $20 \mathrm{~m}$ the light intensity as well as the wave action decrease rapidly with depth (biotopes 1,4 and 7). The number of septa decreases, the teeth are less strong, the calyx is shallower, the paliform lobes are more visible, the corallites are larger and the coenosteum is wider (since the corallites are wider apart). When the corallites are widely separated, as in the bay forms, the theca, costae and septa are thinner than when the corallites in the corallum are arranged closely to each other. In fairly large spherical colonies at the sides and underneath the corallum, where the light influence is less strong, corallites are more apart from one another, with fewer septa, than on top of the corallum.

In short, I can state that within my series of 28 coralla from different environments, all skeleton characters show variation. It is evident that depth is the most important environmental factor influencing coral growth expressed as skeleton formation. All characters of the coral skeleton change with depth but not always at the same rate, because other environmental factors may mask the effect to a certain extent. I have measured two characters in my specimens: (1) Number of corallites per $9 \mathrm{~cm}^{2}$, (2) Number of septa per corallite. The results are shown in figs. 6 and 7. In both series the numbers decrease in relation to greater depth. But it is striking that the amount of skeleton deposit in biotope 1 and 2 is greater than in biotopes 5 and 6, so at a depth of $10 \mathrm{~m}$ in biotope 2 there is more skeleton formation than on $10 \mathrm{~m}$ in biotopes 5 or 6 , probably as a result of better conditions (optimal
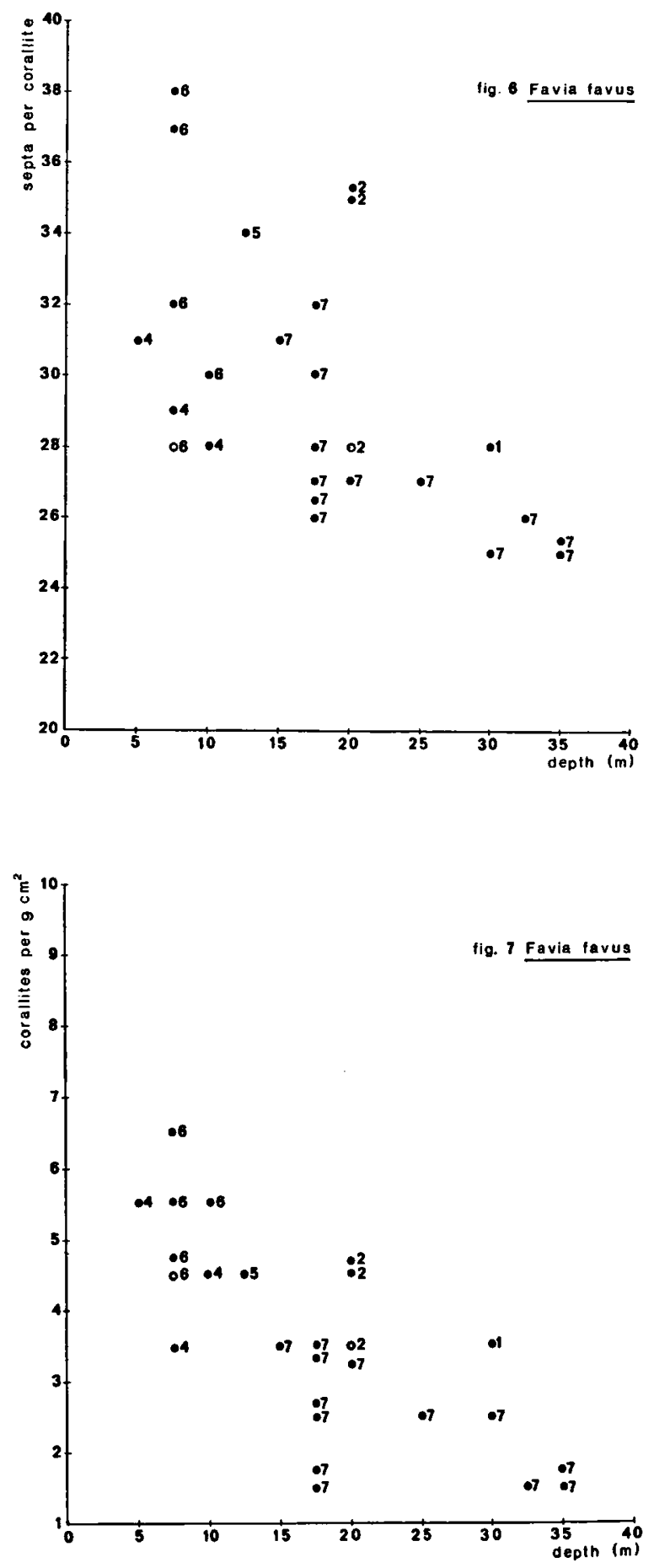

Figs. 6 \& 7. Favia favus. Relations between number of septa per corallite and depth of collecting, and between number of corallites per $9 \mathrm{~cm}^{2}$ and depth of collecting. Numbers indicate the biotopes.

Closed symbols concern the top of the corallum. Open symbols concern the side of the corallum. 
light, optimal circulation of water, no sedimentation). Corals growing in biotopes 4 and 7 have a relatively low skeleton production, from which it may be concluded that the conditions are far from optimal. A full discussion of the graph will be given in chapter IV, since the relation shown is found in all species of the Favinae.

In the present series the general specific characters remain perceptable, especially when the particular biotope of a specimen is considered, even when the extreme forms superficially do not resemble each other as photographs 1 and 5 show. Because transitional forms are present and the colour of the polyp is rather constant in varying environments this series is interpreted here as one species.

These relatively slow growing massive coral heads do contribute to the firmness of the reef and can resist much wave action, so Favia favus is one of the smaller but successful forms on the reefs. It seems that Favia favus with its large corallites is better resistant to a high degree of sedimentation. Colonies found in bays have extremely large polyps, that can be as high as 1 to 1.5 cm (e.g. in Coel. 5704).

\section{Discussion. -}

The lectotype of this species described by Forskål in 1775: 132, and figured by Matthai, 1914 (Pl. 22, fig. 3), is a large corallum (about $15 \mathrm{~cm}$ diameter) from the Red Sea. The specimen corresponds with those from the New Caledonian biotope 6, which can be ascribed to the less intense water action in the Red Sea. Since the colony is spherical the relatively small and deep corallites are close to each other with numerous septa, Forskål's colony represents a shallow water facies. The same holds true for Parastrea affinis (described by H. Milne Edwards \& Haime, 1857: 429) from Malaya, differing from the type of Favia favus in having thinner septa and thecae, as well as for Parastrea geoffroyi (H. Milne Edwards \& Haime, 1857: 433) from the Red Sea, and for Parastrea savignyi (H. Milne Edwards \& Haime, 1857: 437) also from the Red Sea. The holotype of the latter species has a blistered surface which is probably not a specific character but due to some unfavourable environmental influence such as dirty water.

Favia danae (Verrill, 1872), new name for Astraea (Fissicella) porcata Dana (1846: 226), is rather a dubious species. The holotype closely resembles Favia ehrenbergi var. laticollis Klunzin- ger, 1879, as far as can be seen from the photograph given by the latter author. The type of another species of Forskål, Madrepora cavernosa, is from another biotope. It is probably from deeper waters, as the colony is flatter, the corallites are larger, the coenosteum is more developed, and the septa are less numerous. This combination of characters points more to the biotope 4 in New Caledonia. One specimen collected by Crossland 1952: 126 from the Great Barrier Reef in shallow waters, exposed to the open ocean, is called var. crassidens. The thecae and septa are solidly built and the teeth are well developed; it falls within the range of my series from biotope 2 . The type of another outer reef species is Orbicella borradailei Gardiner, 1904: 775, collected at Minikoi (Laccadives), supposedly coming from the same habitat as var. crassidens. One of the remaining synonyms mentioned is Parastrea aspera $\mathrm{H}$. Milne Edwards \& Haime (1857: 438) from the Red Sea. The type specimen is rather strange with deformed, closely packed corallites. It probably belongs to Favia favus, but the specimen seems to have a pathological structure. I base the synonymy of Favia rousseaui on the photograph given by Matthai 1914, pl. 21 fig. 5 and that of Madrepora denticulata Ellis \& Solander 1786: 166 on the drawing by these authors. On comparison with each other, all type specimens mentioned show much variation, which, however, can be considered to fall within an intraspecific range and to be the result of micro-environmental influences.

A few comments can be made on some well labelled specimens that have been examined in other collections. BMNH specimen No. 1888.10. 25.12 labelled Favia denticulata is Favia favus from Mauritius, corresponding with my outer reef specimens (biotope 2). A collection of the present species from the Red Sea shows much resemblance to Forskål's type (especially BMNH No. 27.5.12.137). In the following specimens the relation between skeleton deposit and depth can be generally recognized: ZMA Coel. 5602 from Mauritius (Pointe Vacao, northern Mauritius, lagoon, about $1 \mathrm{~m}$ depth, leg. J. H. Stock); Coel. 1733 from Madagascar (Pointe de la Fièvre, Nosy Bé, reef, ca $1 \mathrm{~m}$, leg. J. H. Stock); Coel. 5754 from Siboga station 273 (off Pulu Jedan, east coast of Aru Islands, bottom sand and shells, dredge up to $13 \mathrm{~m}$ ) which corresponds with specimens of biotope 7 in New Caledonia; Coel. 5755 \& 5756 from Siboga station 301 (Pepela Bay, east coast of Roti Island, up to $22 \mathrm{~m}$ depth), the first one 
probably coming from a shallower site than the latter.

Favia favus has been reported from various localities of the Indian and Pacific Ocean, but many of these specimens were unavailable while descriptions and illustrations often are insufficient. From the foregoing it follows that with certainty the species has been found in the Red Sea, Madagascar, Mauritius, Indonesian Archipelago, Japan, Great Barrier Reef. New Caledonia, Marshall Islands, Samoa Islands.

Favia speciosa (Dana, 1846). Pl. I figs. 1, 2, 3, 4.

Astraea (Fissicella) speciosa Dana, 1846: 220, pl. 11 fig. 1, holotype USNM No. 37.

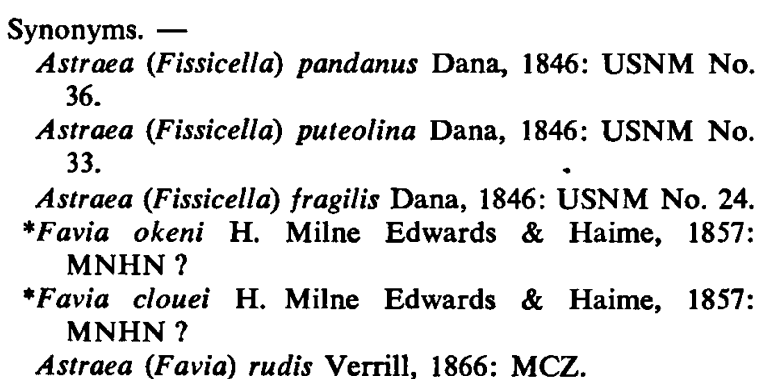

Material. -

New Caledonia collection ZMA (52 specimens):

Biotope 1 - Coel. 5626 - 5628

" 2 - Coel. $5629-5631(2 \mathrm{x})$

" 3 - Coel. $5627(2 \times)-5629$

" 4 - Coel. $5632-5633-5634$

" 5 - Coel. $5635(3 \times)$

" 6 - Coel. 5636 - 5637 - $5638(2 \times)-$ $5639-5640-5641-5642-$ $5643-5644(4 \times)-5645$ $(3 \times)-5646-5647-5648-$ $5649(4 X)-5650(2 \times)-$ 5651.

$" 7$ - Coel. 5652 - $5653(3 \times)-5654-$ $5655-5656-5657-5658-$ $5659-5660-5661-5662$.

Other collections:

ZMA Coel. 5757, 5758 Timor (Lesser Sunda

Coel. 1697,1706
1734,1739 ， Nosy Bé (Madagascar)

RMNH No. 370

Timor (Lesser Sunda Islands)

No. 373

No. 1072

Poeloe Weh (Sumatra)

Togian Reef (Celebes)

Characters. -

Corallum: The colony is plocoid, spherical, flat or encrusting. The calices are more or less rounded, mean diameter $8 \mathrm{~mm}$; the thecae are thin, the
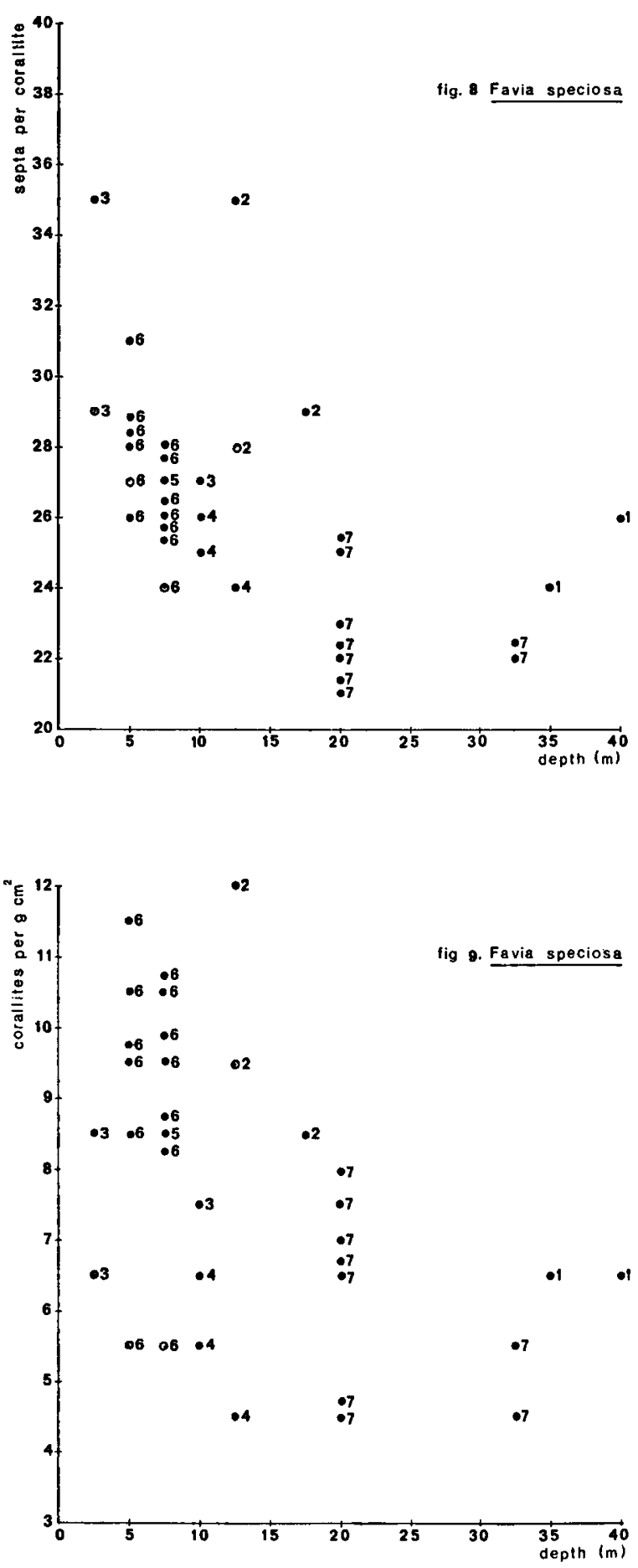

Figs. 8 \& 9. Favia speciosa. Relations between number of septa per corallite and depth of collecting, and between number of corallites per $9 \mathrm{~cm}^{2}$ and depth of collecting.

Numbers indicate the biotopes.

Closed symbols concern the top of the corallum. Open symbols concern the side of the corallum. 
septa regularly exsert; their number varies between 19 and 38 (average 26). The edge of the septa is dentate, the last teeth sometimes forming paliform lobes at the bottom of the calyx. The columella consists of small twisted trabeculae; at the outside of the theca walls the costae are well developed and thin, regularly dentated; these ribs continue on the coenosteum that is variable in width.

Polyp: In general the colour of the polyp is yellowish-brown, with a greenish peristome.

Variability of the characters in the different biotopes. -

For the general trends in variability $I$ refer to the discussion under Favia favus. Again, we find a decrease of skeleton deposit in relation to increasing depth. This species being well represented in my collections, figs. 8 and 9 show very clearly that there is a separate graphic relation of the combined outer barrier reef biotopes 1 and 2, lying distinctly higher, which means that under outer reef conditions the processes concerned with skeleton formation are more effective. The values found for specimens from biotopes 3, 5, and 6 together form another hyperbole-like curve, slightly lower, that is continued by values from biotopes 4 and 7. Biotope 3 falls within the range of 5 and 6, apparently having more in common with the environments of biotopes 5 and 6 than of 1 and 2. In comparison with Favia favus there are more corallites per square unit; therefore, it is easily understood that the average number of septa per corallite is lower.

Since so many specimens of this common species are known, we are fairly well informed about its variability. In the large series there is so much overlap in the variation per biotope that the typical environment induced ecotypes, as found in the other Faviinae, are linked by transitional forms. For this reason the specific names that have been created for growth forms were already considered to be synonymous by modern authors.

Discussion. -

Dana (1846) described Astraea speciosa (:220), Astraea pandanus (:222), Astraea puteolina (:223) and Astraea fragilis (:230), all growth forms of the same common and adaptive species that is present in all seven biotopes. The holotype is a flattened corallum of light structure, corresponding as a whole with a specimen of biotope 4 . The theca is thin and well developed, the septa, about 26 in number, are rather thin and regu- larly built; the coenosteum is about $4 \mathrm{~mm}$ wide. On the sides the surface is blistery, probably as a result of having grown on a sandy bottom. The holotype of Astraea pandanus from the Fiji Islands is a specimen from an optimal habitat; probably from the upper reef zone as the corallum is rounded and the corallites are small and lie close to each other; the average number of septa is 33 and the calyx is deep. At the sides of the corallum, the calices are much further apart and less deep. The holotype of Astraea puteolina is a rounded colony found in the Indonesian Archipelago. The light texture, the many septa which are rather irregularly dentate, and the closely set corallites make it resemble specimens from biotope 3. The characters of the holotype of $A s$ traea fragilis show much resemblance to those of A. puteolina; however, the texture is much more compact. It corresponds to specimens from my biotope 2. As the types of Favia okeni and Favia clouei could not be located in the Paris Museum, I can only deal with the descriptions and photographs given by Matthai, 1914, who synonymized Favia clouei with Astraea speciosa in his publication of 1924. The type of Astraea okeni comes from the Seychelles, probably from quiet water, since the corallites lie far apart, the calices have a diameter of about $12 \mathrm{~mm}$, and the septa are not numerous. Matthai regarded Favia okeni as a synonym of Favia clouei, only differing from the latter in having larger calices. Favia clouei has corallites with a diameter of about $10 \mathrm{~mm}$; the calices are of medium depth, arranged not so close to each other; the thecae are thin; paliform lobes are well developed. The holotype is probably to be regarded as transitional between the deeper water and the surface form. The type of Astraea rudis from the Sandwich Islands (?) is a Favia speciosa with strong teeth formation and thickened septa, probably grown in an exposed site on the reef.

A few comments can be made on some welllabelled specimens that have been examined in other collections. Some Favia speciosa specimens in collection ZMA: Coel. 5757 \& 5758 from Siboga station 296 (Noimini, South coast Timor, reef exploration, bottom sandy mud, at a depth of $13 \mathrm{~m}$ ). Both specimens correspond with colonies from biotope 3. Coel. 1706, 1734 \& 1739 are specimens from Madagascar, Pointe de la Fièvre, Nosy Bé, reef, 1-5 m, leg. J. H. Stock. They are heavily built, rounded coralla with strong denticles. Coel. 1697 from Madagascar, Pointe Loko- 
bé, Nosy Bé, reef, at a depth of about $4 \mathrm{~m}$, leg. J. H. Stock, is a corallum with regular corallites and less teeth formation, so probably from a more sheltered biotope. RMNH No. 1072 from a sheltered inner reef site, corresponds to specimens of New Caledonia biotope 3. The morphology of these specimens confirms my theory of the variability in the Faviinae, with a certain restriction due to the different circumstances that may be present in other areas. Only a few specimens are sufficiently labelled to get the necessary information. In these, however, the same trend as found in my series can be recognized.

It is not surprising that in literature most specimens found are called pandanus type, because this type is from a reef habitat where collecting was mostly done.

As to the geographical range I can state with some certainty, because the specimens have been seen or the description or photograph is good enough to be sure, that Favia speciosa is found in the following areas: Red Sea (e.g. BMNH No. 28.9.1.104), Madagascar, Seychelles, Murray Islands, Cocos Keeling, Singapore (e.g. ZMA Coel. 5759), Indonesian Archipelago (Sumatra, Timor, Moluccas, Celebes, Bay of Batavia), southern Philippines, Great Barrier Reef, New Caledonia.

Favia pallida (Dana, 1846). Pl. II figs. 3, 4.

Astraea (Fissicella) pallida Dana, 1846: 224, pl. 10 fig. 13, holotype USNM No. 30.

Synonyms. -

Favia doreyensis H. Milne Edwards \& Haime, 1850. MNHN.

*Parastrea urvilleana H. Milne Edwards \& Haime, 1850. MNHN ?

Parastrea amplior H. Milne Edwards \& Haime, 1850. MNHN.

Astraea ordinata Verrill, 1866. MCZ No. 384.

Astraea cellulosa Verrill, $1872=$ Astraea (Fissicella) denticulata Dana, 1846. USNM No. 77.

* Goniastrea serrata Ortmann, 1889. MZS ${ }^{2}$ ).

Favia laccadivica Gardiner, 1904. BMNH No. 28.9.1.63.

Material. -

New Caledonia collection ZMA (18 specimens):

Biotope 2 - Coel. 5666 - 5667 - 5668

" 3 - Coel. $5663-5664$

" 4 - Coel. $5669-5670$

" 6 - Coel. 5665

" 7 - Coel. 5671 - 5672 - $5673(2 \times)-$ $5674-5675-5676-5677$

Other collections:

ZMA Coel. 5767

Coel. 5770

Binongka (Celebes)

Dangar Besar (Sumbawa)

2) MZS = Musée Zoologique de l'Université de Strasbourg. See note 3 on page 19.

\author{
Coel. 5768, 5769 \\ Coel. 1705,1707 \\ 1708,1740 Nosy Bé (Madagascar) \\ Coel. 5771 \\ Buru (Moluccas) \\ USNM. Unregistered collection Ladd \& Tracey from \\ Bikini Atoll
}

RMNH No. 1073

\section{Characters. -}

Corallum: The colony is plocoid, spherical, flat or encrusting. The corallites are round to oval, often capriceous of form by di-stomodaeal or tristomodaeal budding; the average diameter is 8 $\mathrm{mm}$. The thecae are rather thick, the septa are not numerous, 16-32 (average 23), the primary ones are $2-3 \mathrm{~mm}$ exsert, while the rest is unequal in height; the paliform lobes are well-developed and arranged in a circle around the small columella. The costae are not always present and do not continue on the coenosteum, that is variable in width. Polyp: Generally the polyp is brown-greygreen in colour, sometimes with a purple bloom.

Variability of the characters in the different biotopes. -

The general trend as described for Favia favus is also visible in this species. The series is not large enough for a detailed discussion or graphical treatment. The specimens, however, from biotopes $2,3,4,6$, and 7 do show the environment induced variability expected: strongly built, rounded, well-dentated coralla from biotope 2; coralla of the same habit but smoother from biotopes 3 and 6; and a decrease in skeleton deposit for the specimens from biotopes 4 and 7 . (See also the following table):

\begin{tabular}{lrrrrr} 
Biotope & 2 & 3 & 4 & 6 & 7 \\
\hline $\begin{array}{l}\text { Average number of septa per } \\
\text { corallum }\end{array}$ & 25 & 25 & 23 & 23 & 19 \\
$\begin{array}{l}\text { Average number of corallites } \\
\text { per } 9 \mathrm{~cm}^{2}\end{array}$ & 10 & 10 & 8 & $8-9$ & 6
\end{tabular}

The values for biotope 4 are not typical because both specimens came from a depth of $10 \mathrm{~m}$, so real lagoon specimens are not present within my series. Vaughan (1918) discusses six facies types from habitats roughly corresponding with my biotopes 3 and 4 . This number is a clear indication of the large degree of variation in the present species. In the chapter on ecology I shall deal with Vaughan's observations again.

\section{Discussion. -}

The holotype (see Vaughan, 1918, pl. 38 fig. 1) is a flattened colony from the Fiji Islands, corresponding in morphology with my Favia pallida from biotope 4; so probably it was growing in a 
quiet spot. The corallites are relatively large (10 $\mathrm{mm}$ ), not deep and rather widely separated from each other; the thecae and septa are thin and regularly dentate. Favia doreyensis (H. Milne Edwards \& Haime, 1850: 168) does show much resemblance to the type of Dana. Because the thecae and septa are thin and not numerous, the denticles are hardly developed and the large corallites are rather widely separated from each other; the holotype (see Matthai, 1914, pl. 22 fig. 8 ) resembles the colonies from my biotope 3 . The holotype of Favia urvilleana $(\mathrm{H}$. Milne Edwards \& Haime, 1850: 169) is lost, but according to Matthai, 1914 who has seen the specimen, it looked much like Favia doreyensis. Judging from the description of $\mathrm{H}$. Milne Edwards \& Haime the corallum is a Favia pallida from a rather exposed, i.e. shallow reef biotope. The holotype of Parastrea amplior (H. Milne Edwards \& Haime, 1850: 172 ) is a specimen with rather large, but closely set corallites with a shallow calyx; it probably comes from a quiet but shallow spot. The holotype of Astraea ordinata Verrill, 1866: 34 comes from the Hongkong area and is a very worn specimen. Vaughan, 1918 provides a good description of the holotype of Astraea cellulosa Verrill, 1872, a specimen from the East Indies, misidentified by Dana, 1846: 234 as Astraea denticulata Ellis, 1786. It is a reef form, corresponding with those from my biotope 3. The holotype of Goniastrea serrata Ortmann, 1889: 526 could not be traced 3 ), but judging from the description and photograph, this species falls within the growth form series of Favia pallida, probably coming from an exposed reef biotope. Favia laccadivica Gardiner, 1904: 769 was found in the lagoon shoals of Minikoi, which explains the regularity in the skeleton structure. Two possible synonyms of Favia pallida are mentioned by Vaughan, 1918, and some later authors, viz. Favia hululensis Gardiner, 1904: 769 and Favia rotulosa Ellis \& Solander, 1786: 166. But after studying the types of both I came to the conclusion that they are not synonymous with Favia pallida, because they do not fall within the growth form series. They may be synonymes of one another, but I accept at least one valid Pacific Favia species, for which the name Favia rotulosa Ellis \& Solander is available, and which is not present in my New Caledonia collections.

8) After the manuscript was completed, I received some good photographs of the holotype in the Strasbourg Museum. The present conclusions are not in the need to be changed.
I shall refer to this species on page 66 .

In literature (Vaughan, 1918; Wells, 1954) the variability of this common species has been described extensively. Many of the specimens on which their discussion was based have been examined by me in the USNM. Specimens from the 5 facies described by Vaughan are all coming from the shallow sheltered reef flat of Murray Island at different distances from the shore, so they show the variability range seen in my series from biotopes 3 and 4. Wells worked with an extensive collection from the Marshall Islands, where Favia pallida appeared to be the most abundant species, having a variability range corresponding with my biotopes 2 and 4 . I shall return to these ecological studies in my general discussion on ecology.

Some Favia pallida specimens in the collection ZMA: Coel. 5767 is a large corallum from Siboga station 220 (West coast Binongka, reef exploration, bottom coral sand) showing a very regular skeleton structure, probably having grown in very quiet, shallow water. Coel. 5770 from Siboga station 313 (Dangar Besar, dredge and reef exploration, bottom mud and sand, depth up to 36 m) corresponds with my specimen Coel. 5669 of biotope 4. Coel. 5768 and 5769 from Siboga station 213 (Saleyer Anchorage and surroundings, trawland reef exploration, bottom sand, mud, depth up to $36 \mathrm{~m}$ ) showing a skeleton structure corresponding with specimens of biotope 3. Coel. 1705, 1707, 1708 and 1740 from Madagascar (Pointe de la Fièvre, Nosy Bé, reef, depth about $2 \mathrm{~m}$, leg. Stock) show a normal strong structure (reeftype). Coel. 5771 from Buru, Indonesia (Leksoela, coral reef, leg. Toxopeus) is a very regularly built specimen from a sheltered niche.

Favia pallida is a widely distributed Pacific species. With certainty it is known from the following localities: Madagascar, Maldives, Philippines, Indonesian Archipelago, Torres Straits, New Caledonia, Fiji Islands, Minikoi, Marshall Islands, Samoa.

Favia matthai Vaughan, 1918. P1. III fig. 1.

Favia matthai Vaughan, 1918: 109, pl. 39 fig. 2, holotype USNM No. 38381.

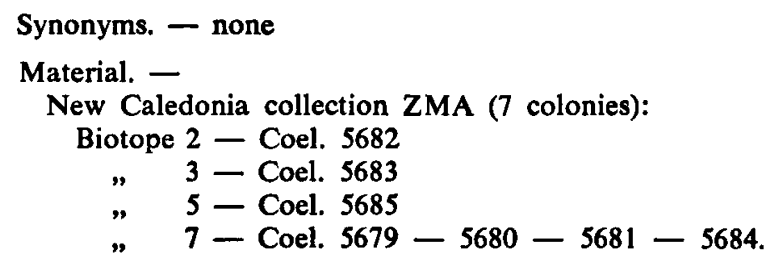


Other collections:

ZMA Coel. 1719

Coel. 5763

Coel. 5765

Coel. 5764

Coel. 5766

RMNH No. 1074, 1075, 1076
Nosy Bé (Madagascar)

Roti Island (Lesser

Sunda Islands)

Timor (Lesser Sunda Islands)

Dangar Besar (Sumbawa)

Saleyer (Java Sea)

Togian Reef (Celebes)

Characters. -

Corallum: The colony is plocoid, spherical, flat or encrusting. The corallites are circular, the average diameter is $8 \mathrm{~mm}$. Sometimes we find extratentacular budding. The theca is hardly developed. The septa (average 30 in number), especially the primary ones, can be 2 or $3 \mathrm{~mm}$ exsert with strong denticulations; the last teeth may form paliform lobes around the small columella that consists of some septal teeth. The costae are thin or absent; the coenosteum can be of various width between the corallites.

Polyp: In general the polyp is red brown with a greenish-blue stomodaeum (under UV light the polyp is very strongly fluorescent red).

Variability of the characters in the different biotopes. -

The series is not large enough for a detailed discussion or graphical treatment. The specimens, however, that are present from biotopes 2, 3, 5, and 7 show more or less the environment induced variability expected. Coel. 5682 has grown at a depth of $15 \mathrm{~m}$ outside the barrier reef and shows much resemblance to Vaughan's type, the septa are thin and well dentated, and the corallites are fairly well separated from each other, at the sides of the corallum even as far as $6 \mathrm{~mm}$ apart. Coel. 5683 also comes from an exposed biotope (in the Passe de Bulari) but from a shallower site (about $5 \mathrm{~m}$ ), the septa are strongly built and the corallites are closely set. Coel. 5685 from Porc Epic (about $10 \mathrm{~m}$ ) has a much more regular appearance as to the denticles. The corallites rise up from the coenosteum to a maximum height of $6 \mathrm{~mm}$. The specimens from the bay biotope 7 show flat coralla with widely separated corallites (sometimes 1 to $1.5 \mathrm{~cm}$ apart). As to the skeleton structure these specimens show much resemblance to the bay growth form of Favia pallida; they are referred to the present species primarily because of the red polyps.
Discussion. -

The holotype (Vaughan, 1918: 109) is a specimen collected by W. L. Abott in the western Indian Ocean (the exact locality is unknown). As stated, the specimen corresponds to my colony from biotope 2 . Subsequently the present species has been referred to only once, viz. by Umbgrove, 1940: 278. RMNH No. 1075 from the outer reef of Batoe Daka (Togian Bay, Celebes) resembles Vaughan's holotype, which supports my supposition that the latter probably comes from the outer reef.

Some further specimens of Favia matthai in the collection ZMA: Coel. 5765 from Siboga station 282 (Timor, reef exploration, depth 27 to $34 \mathrm{~m}$, bottom sand) and Coel. 5766 from Siboga station 213 (Saleyer, reef exploration, depth up to $36 \mathrm{~m}$, bottom mud, sand) are deep water growth forms having flat coralla, widely separated corallites and a regular appearance. Coel. 5763 from Siboga station 299 (Roti Island, reef exploration, depth up to $34 \mathrm{~m}$, bottom mud) and Coel. 5764 from Siboga station 313 (Dangar Besar, reef exploration, depth up to $36 \mathrm{~m}$, bottom sand and mud) are from shallower water having rounded coralla with closely set corallites. Coel. 1719 from Madagascar (Pointe de la Fièvre, Nosy Bé, reef, $2 \mathrm{~m}$, leg. J. H. Stock) is a typical reef specimen.

The species has been reported from the western Indian Ocean, Madagascar, the Indonesian Archipelago, and New Caledonia.

Favia rotumana (Gardiner, 1899). Pl. III fig. 2.

*Astraea rotumana Gardiner, 1899: 750, pl. XLVII fig. 3, holotype University Museum Cambridge, lost.

Synonyms. - none.

Material. -

New Caledonia collection ZMA (6 colonies):

Biotope 1 - Coel. 5686 - 5690

" 2 - Coel. $5687-5688-5689$

" 6 - Coel. 5691 .

Other collections:

ZMA Coel. 5762

MCZ No. 5370

Samau Island (Timor) Makemo (Tuamotu).

Characters. -

Corallum: The colony is plocoid, spherical, flat or encrusting. The corallites are rounded to oval, often capriceous of form and rather closely set, sometimes even with a Favites-like structure. The most striking feature is the irregularity of thecae 
and septa; the latter are unequally exsert and especially in the exposed biotopes very dentated. The diameter of the corallite is about 1 to $1.5 \mathrm{~cm}$. The average number of septa is 23 , the primary cycles are sometimes thickened; the paliform lobes are well developed. The columella is small, consisting of a few trabeculae. On the coenosteum, developed only in growth forms from deeper water, the costae are hardly visible.

Polyp: The colour of the soft parts is of a remarkable grey-greenish-blue, mostly of a light shade.

Variability of the characters in the different biotopes. -

This series is not large enough for graphical treatment. The specimens from biotopes 1 and 2 show much resemblance, being typical reef forms coming from depths between 15 and $25 \mathrm{~m}$. Coel. 5691 is a more flattened colony, strongly built, but with much less dentation, larger corallites, and more coenosteum formation.

\section{Discussion. -}

I am convinced that the material at hand constitutes a valid species but since the type specimen of Gardiner is lost (Goodhart in litt. 1971), I cannot be sure whether the specific name is correct. The photographs as well as the description, however, made me decide to accept the name rotumana for the present small series of corals. The holotype was a part of an encrusting flat colony from Rotuma, probably a growth form from a sheltered habitat, in view of the rather smooth and little numerous septa. Hoffmeister, 1925: 24 recorded the species from Samoa and gives very good photographs, which bear out the great resemblance to my reef specimens. Wells, 1954: 458 mentioned the species from the Marshall Islands.

ZMA Coel. 5762 from Siboga station 303 (Haingsisi, Samau Island, reef exploration, depth up to $36 \mathrm{~m}$ ), is a large rounded corallum from an exposed reef habitat. MCZ No. 5370 from the lagoon of Makemo Island, Tuamotu, is a rather light corallum with an average septa number of 23 and less dentation; a typical lagoon growth form.

The species has been recorded from the Indonesian Archipelago, Rotuma, Samoa, Marshall Islands, New Caledonia, Tuamotu. I do not agree with the identification of Yabe, 1936: 29 (see also Wells, 1954)of Palau specimens, neither with the one of Nemenzo, 1959: 91 of Philippine specimens.
Favia amicorum (H. Milne Edwards \& Haime, 1850). Pl. III figs. 3, 4.

Parastrea amicorum H. Milne Edwards \& Haime, 1850: 171, holotype MNHN (new name for Astrea ananas Quoy \& Gaimard, 1833; non Astrea ananas Lamarck, 1816).

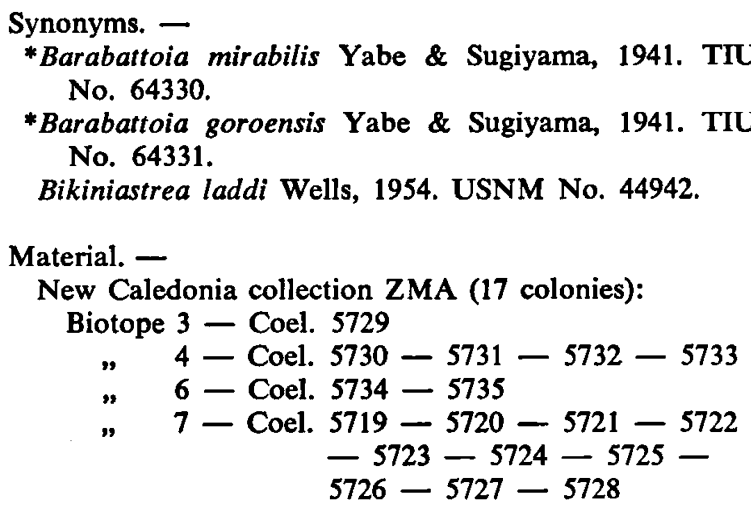

Characters. -

Corallum: The colony is plocoid to subdendroid, spherical to flat. The calices are mostly rounded, with an average diameter of $9 \mathrm{~mm}$. There is a tendency to grow upwards, so the length of the thecae is variable (sometimes 1 to $1.5 \mathrm{~cm}$ high); the asexual reproduction can occur by budding at the sides of the corallite; then it is extratentacular, but in general there is intratentacular budding. The septa are of even height, they are numerous with a maximum of 40 and a minimum of 24 (average 29), and they are rather thin. The denticles are regular, within the calyx the last teeth often form a horizontal plateau of paliform lobes dropping down to the columella. At the outside of the theca the regular teeth continue on the well-developed costae (like beads). Between the costae corresponding with the septa, sometimes intercostal ridges can be found. The columella is small, consisting of fine trabocular teeth. The coenosteum is of variable width and depth.

Polyp: In general the living animal is of a yellowish-brown colour with a light green stomodaeum.

Variability of the characters in the different biotopes. -

The present series of this species is not large enough for graphical treatment. Besides, the species is represented mostly from the lagoon and bay facies, biotope 6 is represented by specimens from a sandy bottom in shallow water to be regarded as a continuation of the lagoon towards the reef. It is quite possible that the species is steno- 
topic, and it is difficult therefore to get a clear picture of the extent of the variation in the number of septa per corallite and in the number of corallites per square unit. The following data can be given, however, showing the relation between the morphology of the specimens and the biotopes where they were found.

\begin{tabular}{lccccc} 
Biotope & 1 & $\begin{array}{c}4 \\
\text { depth } \\
>10 \mathrm{~m}\end{array}$ & $\begin{array}{c}4 \\
\text { depth }\end{array}$ & 6 & 7 \\
& $<10 \mathrm{~m}$ & & \\
\hline $\begin{array}{c}\text { Average number of septa } \\
\text { per corallum }\end{array}$ & 26 & 27 & 29 & 31 & 27 \\
$\begin{array}{c}\text { Average number of coral- } \\
\text { lites per } 9 \mathrm{~cm}^{2}\end{array}$ & 5 to 6 & 5 to 6 & 8 to 9 & 8 to 9 & 5 to 6
\end{tabular}

Coel. 5729 is a reef specimen from about $30 \mathrm{~m}$, resembling Coel. 5722 from Baie de Dumbéa from about $15 \mathrm{~m}$ in the flattened colonies and further skeleton characteristics. The specimens from the shallow lagoon facies belong to two categories, viz. above and below a depth of $10 \mathrm{~m}$. The coralla from biotope 6 fall within the range of biotope 4 above $10 \mathrm{~m}$, and show like these spherical, well-built colonies with numerous septa and rather closely set corallites (the mirabilis form). The specimens from facies 4 below $10 \mathrm{~m}$ correspond with the bay forms, having larger and protruding coralla, rather clearly separated from each other and with fewer septa (the laddi form).

\section{Discussion. -}

The holotype is a specimen from Tongatabu collected during the voyage of the "Astrolabe" and described by Quoy \& Gaimard, 1833: 207 as Astrea ananas. Because this name was preoccupied by Lamarck, 1816, H. Milne Edwards \& Haime, 1850: 171 changed the name into Parastraea amicorum. It is a growth form from a rather deep sandy lagoon facies, corresponding with Coel. 5731, but differing by a smoother skeleton structure. Barabattoia mirabilis Yabe \& Sugiyama, 1941: 72 is based on a specimen from the Islands of Yap. Yabe \& Sugiyama's figures $1^{\mathrm{a}}$ to $1^{\mathrm{e}}$ on pl. LXI are extremely good and have convinced me that I am dealing with Favia amicorum. The holotype corresponds with Coel. 5730, that comes from a shallow bay-lagoon facies. Barabattoia goroensis Yabe \& Sugiyama, 1941: 73 comes from south-eastern New Caledonia. The specimen was probably collected as a dead and worn corallum, having lived in deeper or anyway quiet lagoon water; the colony is flattened and there are about 30 septa. Coel. 5732 (fringing reef, close to lagoon, $10 \mathrm{~m}$ ) does show more resemblance to the latter species of Yabe \& Sugiyama. The type of a new genus, Bikiniastrea laddi Wells, 1954, 456 is also included ip the present species. The holotype has been found in Bikini atoll lagoon at $30 \mathrm{~m}$ and shows resemblance to some of my bay growth forms. The greater part of the corallum was dead. Is is possible that the loose skeleton structure, not covered by living tissue, was partly demolished by the action of bacteria living in the bottom sediment (see Di Salvo, 1969) and therefore now shows a dendroid structure. Coel. 5728 has the same dendroid growth form.

I have not come across specimens in other collections, so the present species apparently is not a common one, neither in the Indo-Pacific, nor in New Caledonia.

The range of the species extends over the western Pacific, specimens having been found at Tongatabu, Yap, Marshall Islands, and New Caledonia.

Favia valenciennesi (H. Milne Edwards \& Haime, 1850). Pl. IV figs. 1, 2.

Phymastrea valenciennesi H. Milne Edwards \& Haime, 1850: 124, holotype MNHN.

\section{Synonyms. - \\ *Parastrea bertholleti Valenciennes Ms., H. Milne Ed- wards \& Haime, 1857. MNHN ? \\ Phymastrea valenciennesi H. Milne Edwards \& Haime, 1850. MNHN. \\ * Phymastrea profundior H. Milne Edwards \& Haime, 1850. MNHN? \\ Phymastrea irregularis Duncan, 1883. BMNH. \\ Phymastrea aspera Quelch, 1886. BMNH No. 86.12.9. 151. \\ Favia eridani Umbgrove, 1940. RMNH No. 1080.}

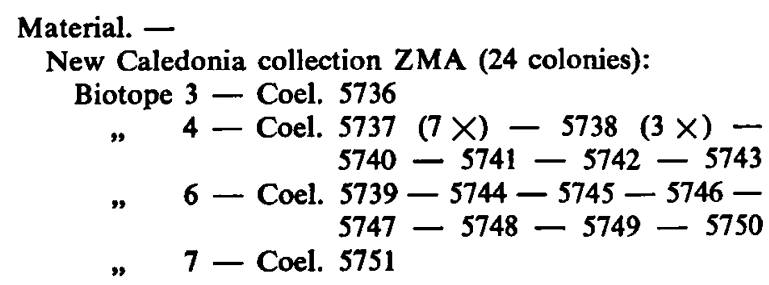

Other collections:

ZMA Coel. 1735 Nosy Bé (Madagascar)

RMNH No. 7096

Bay of Batavia (Indonesia)

USNM. Unregistered

specimens collected by

Steere.

Southern Philippines 
Characters. -

Corallum: The colony is plocoid to phaceloid, spherical, flat or encrusting. The calices are rounded to angular, with an average diameter of $8 \mathrm{~mm}$ (maximum $11 \mathrm{~mm}$ ). The most striking feature is the narrow and deep groove between the corallites (phaceloid appearance). Sometimes the coenosteum is broader: then the morphology is normally plocoid. The thecae are thin. In the high phaceloid corallites, buds are often visible on the wall, giving the colony an extratentacular habit. However, in general the asexual reproduction is intratentacular. The septa are of even height, regular and dentated, the average number is 26 (maximum 32, minimum 21). Inside the calyx the septum drops down vertically, at the end forming a paliform lobe. The columella consists of fine trabeculae. At the outside of the wall the costae are well-developed, regular, often having intercostal ridges. When present, the coenosteum also bears these dentated ridges. Often, in the coenosteum rounded or oval openings are found, as described by Rosen, 1968, as the "groove and tubercle structure".

Polyp: In general the colour of the living animal is a mixture of brown, grey and green with a light green stomodaeum. Most specimens give a variegated impression.

Variability of the characters in the different biotopes. -

With Favia amicorum this species has a preference for the same biotope in common: the sandy lagoon or bay facies. The series is large enough to give a reliable picture of the variability, but because this species is stenotopic, the trend could not be followed in all different biotopes. Coel. 5736 is found at a depth of $10 \mathrm{~m}$ on the sandy bottom of the Fausse Passe. The other reef specimens (biotope 6) are found on the reef facing the lagoon. The table below gives an impression of the morphological trend as found also in the other species of Favia.

In general, the growth forms from deeper waters $(10$ to $15 \mathrm{~m})$ have larger corallites, that are clearly separated from each other (the plocoid bertholleti form). The typical valenciennesi form is from a shallower habitat. Rosen, in his study about the groove structure (1968), also divides this species into two facies types that he takes for pathologic, whereabout I have my doubts. Most of my specimens showing this groove structure look very healthy. An explanation for the occurrence of small tubercles I cannot give, however.

\begin{tabular}{cccc} 
Biotope & $\begin{array}{c}\text { Depth } \\
\text { in } \mathrm{m}\end{array}$ & $\begin{array}{c}\text { Average number } \\
\text { septa/corallite }\end{array}$ & $\begin{array}{c}\text { Average num } \\
\text { corallites/9 }\end{array}$ \\
\hline 3 & 10 & 24 & 11 to 12 \\
4 & 10 & 23 & 9 to 10 \\
4 & 10 & 23 & 11 to 12 \\
4 & 10 & 24 & 9 to 10 \\
4 & 10 & 24 & 12 to 13 \\
4 & 8 & 26 & 8 to 9 \\
4 & 5 & 26 & 15 to 16 \\
4 & 5 & 26 & 17 \\
4 & 5 & 27 & 13 to 14 \\
4 & $5-8$ & 27 & 13 to 14 \\
6 & 5 & 25 & 17 \\
6 & 5 & 26 & 13 \\
6 & 5 & 26 & 18 \\
6 & 5 & 26 & 13 to 14 \\
7 & 15 & 23 & 8 to 9
\end{tabular}

Discussion. -

This species often has been put in the separate genus Phymastrea, even by modern authors like Yabe \& Sugiyama, 1936, and Umbgrove, 1939. But the tendency in the corallites of growing upwards (giving rise to a groove-like structure in this species) can be seen as an ecological adaption present in some other Favia species as well. The type of H. Milne Edwards \& Haime, 1850: 124 is a specimen from an unknown locality, but in my opinion a typical shallow lagoon colony corresponding with growth forms of biotope 4 . The holotype is a good specimen showing the characters of the species rather clearly. The type of Favia bertholleti, described in a manuscript by Valenciennes, could not be traced in the Paris museum. According to Matthai, 1914, it came from the Seychelles and is considered a synonym of valenciennesi. Phymastrea profundior $\mathrm{H}$. Milne Edwards \& Haime, 1950: 125 from an unknown locality, has not been found either in the Paris museum. According to the description, it probably belongs to the present species. Phymastrea irregularis Duncan, 1883: 409 was found on the West coast of India in shallow water. The specimen corresponds with my Coel. 5737 coming from a shallow, exposed biotope. Duncan remarks that "the new, form is distinguished from its nearest ally Phymastrea profundior $\mathrm{H}$. Milne Edwards \& Haime by having well developed costae, non-exsert septa and extremely irregular calices". In my opinion such features depend on environmental factors and are not of specific value. Phymastrea aspera Quelch, 1886: 105, based on a specimen from Banda, also belongs to Favia valenciennesi; it is a growth form from a deeper lagoon facies. The holotype of Favia eridani Umbgrove, 1940: 279, from Cele- 
bes (Batoe Daka, Tandjong Batoetigang, fringing reef) is nearly identical with Coel. 5745 (fringing reef, $10 \mathrm{~m}$ ). At first sight this colony does not look like Favia valenciennesi, because the less closely arranged corallites do not leave the characteristic narrow groove between them. But as the rest of the characters does correspond and in view of the general trend seen in my series of Faviinae, viz. that the coenosteum is wider in deeper water growth forms, I consider Favia eridani an ecotype of the present species.

In other collections the following specimens have been come across: In the British Museum (Natural History) there is a large collection of this species, although many specimens are wrongly identified. A few from Ceylon belong to the lagoon growth forms. In the USNM collection one of the southern Philippines colonies collected by J. B. Steere is labelled Phymastrea aspera Quelch; it belongs to the present species. ZMA Coel. 1735, a shallow reef colony from Madagascar (Pointe de la Fièvre, Nosy Bé, reef, coll. Stock) is a Favia valenciennesi.

The species is known from the following localities: Madagascar, Seychelles, West coast of India, Ceylon, Indonesian archipelago (Banda, Celebes), Philippines, Japan, Taiwan, Great Barrier Reef, New Caledonia, Marshall Islands.

Favia stelligera (Dana, 1846). Pl. IV fig. 3.

Astraea (Orbicella) stelligera Dana, 1846: 216, holotype USNM No. 55.

Synonyms. -

Parastrea lobata H. Milne Edwards \& Haime, 1850. MNHN.

Parastrea hombronii Rousseau, 1854. MNHN.

Plesiastrea armata Verrill, $1872=$ Astraea (Fissicella) intersepta Dana, 1846. USNM No. 65.

Favia stelligera var. fanningensis Vaughan, 1918. USNM No. 45559.

Material. -

New Caledonia collection ZMA (1 colony): Biotope 2 - Coel. 5752

Other collections:

ZMA Coel. $5761 \quad$ Haingsisi (Timor)

RMNH No. 1077, 1078, $\left.\begin{array}{r}1079,7102\end{array}\right\}$ Togian Reef (Celebes)

BMNH. One unregister-

ed specimen collected by

Bourne from

USNM No. 44943

MCZ No. 467
Characters. -

Corallum: The colony is plocoid, often having a hillocky appearance. The corallites have an average diameter of $3 \mathrm{~mm}$; because the asexual reproduction is sometimes extratentacular the species often resembles an Orbicella (subfamily Montastreinae), but in general there is intratentacular budding. The thecae are hardly developed, the septa are evenly exsert, regularly dentated, and about 20 in number (with a minimum of 17 and a maximum of 24); the primary ones form a welldeveloped paliform rod. The columella is small, consisting of a few trabeculae. Outside the theca the costae are to be seen as prolongations of the septa; they do not fuse with each other on the coenosteum.

Polyp: The colour of the living animal is light brown.

Variability of the characters in the different biotopes. -

Not much can be said about the variability since only one colony is present. The morphological variation of this colony is rather remarkable. The corallum is hillocky; the corallites on top of the "hills" are large but rather worn; at the hill side they are large and regularly built, while in the valleys they become much smaller and more closely set. This can probably be explained by the accessibility for water. The variation within one colony due to differences in external influences on the surface of the corallum will be discussed in chapter IV.

\section{Discussion. -}

The holotype (Dana, 1846: 216) is a small hillocky colony from the Fiji Islands. Probably it comes from a reef facies, the structure of the corallites much resembling Coel. 5752. The first record of the species in literature is probably that of Linnaeus, 1767, but for reasons summarized by Vaughan, 1918: 101 the species name acropora Linnaeus is not available for any coral. Parastrea lobata H. Milne Edwards \& Haime, 1850: 171, from the Red Sea, is based on a specimen with a rather smooth appearance with closely set corallites, probably to be regarded as a growth form from quiet surroundings (most Red Sea corals show already a smoother habitus; see discussion under Favia favus). The holotype of Parastrea hombroni Rousseau, 1854: 122, is a large hillocky corallum from "Océanie?" not very different from Coel. 5752. Plesiastrea armata Verrill, 1872, is 
based on a specimen from the East Indies described by Dana, 1846: 246, as Astraea (Fissicella) intersepta. The colony is small and spherical, very typical for this species. Favia stelligera var. fanningensis Vaughan, 1918: 103, is based on a large specimen from Fanning Island. According to the author the corallum is "very light textured, resembling Favia laxa (Klunzinger) in that character and differing from the usual relatively dense skeleton texture of $F$. stelligera". Apart from the light texture, the corallites are large and the skeleton deposit is less, so the thecae, septa and costae are not well developed. Because these features are quite normal in other species of Faviinae, I regard this specimen as an ecotype of a deeper or less illuminated facies rich in sedimentation.

In other collections there are several specimens belonging to this species and according to literature the species is not rare at all. The reason why there is just one representative in my collection must be bad luck or perhaps rarity of the species around New Caledonia. Crossland, 1952, mentions the species to be rare at the Great Barrier Reef, so it is possible that it is rare in New Caledonia too. In the BMNH there are many colonies labelled Favia acropora, most of them showing the normal reef habitus. One specimen called Favia lobata H. Milne Edwards \& Haime from Chagos Archipelago (coll. G. C. Bourne) belongs to Favia stelligera. It shows indeed the same smooth habitus as the holotype of Favia lobata. In RMNH the Umbgrove specimens from Togian reef (Celebes) are present. Most of these are normal barrier reef forms found at the barrier reef of Batoe Daka; no 1079 . however, has larger and widely separated corallites and comes from the East atoll, so probably from a more sheltered habitat. MCZ no. 467, labelled Favia hombroni $\mathrm{H}$. Milne Edwards \& Haime from the Sandwich Islands, is Favia stelligera. In the USNM many colonies belonging to the present species are present. No. 44943 from Bikini atoll is a small rounded colony with small, closely set corallites, typical for a shallow reef facies. ZMA Coel. 5761 is a specimen from Siboga station 60, Timor (Haingsisi, shore exploration, up till $23 \mathrm{~m}$ ), probably from an exposed reef facies.

From the known data it can be concluded that Favia stelligera prefers a shallow reef habitat; the small corallite and the hillocky structure give resistance to wave action; this structure offers no selective advantages in the process of easy removal of sediment.
This wide-spread species occurs in the Red Sea, Chagos Archipelago, Indonesian Archipelago (Celebes, Timor, Bay of Batavia), Philippines, Great Barrier Reef, New Caledonia, Marshall Islands, Fiji Islands, Fanning Islands, and Hawaiian Islands.

Favia laxa (Klunzinger, 1879). Pl. IV fig. 4.

Orbicella laxa Klunzinger, 1879: 49, pl. V fig. 3, holotype ZMB No. 2193.

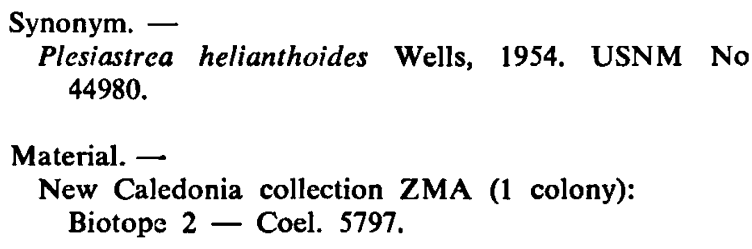

USNM. Unregistered specimens collected by

Fehlmann from No. 44980

Palau Islands

Bikini (Marshall Islands)

\section{Characters. -}

Corallum: The colony is plocoid, often having the same hillocky appearance as Favia stelligera. The average diameter of the corallite is $9 \mathrm{~mm}$, the asexual reproduction is mostly intratentacular, which supports the position in this genus. The presence of extratentacular budding and regular rounded corallites makes the species resemble Orbicella. The theca is thin, the septa very regular exsert and finely dentated; their average number is 21 (with a maximum of 25 and a minimum of 17); they drop down vertically into the calyx and the primary ones form regular paliform rods that together surround the small columella as a crown. The costae are also finely dentated and are to be seen at the outside of the wall; they do not fuse with each other on the coenosteum. Intercostal ridges are present.

Polyp: The colour of the living animal is light brown.

Variability of the characters in the different biotopes. -

The species is rare. With only one representative in my series nothing can be said about its variability. Within one colony an unusual regularity is seen; only in the "valleys" the corallites become 
much smaller, as is always the case in coralla with much relief on the surface.

\section{Discussion. -}

In Klunzinger, 1879: 49, the holotype is well figured (pl. V. fig. 3). Only the side where the corallites are larger and further apart is shown, on the other side the intratentacular budding is better visible. The specimen was found at Koseir (Red Sea), and had brown polyps. The type of Favia helianthoides Wells, 1954: 458, presumably belongs to the present species, but comes from another facies. The spherical heavy corallum with the closely set corallites is from a more exposed site than the Red Sea specimen of Klunzinger. Wells collected also other specimens at Bikini Atoll (USNM), e.g. in the lagoon, that correspond more closely with the species type.

Because the species is rare there are few records in literature. However, in some collections I incidentally came across a representative of it. In the USNM there is a collection from the Palau Islands (High Island Project, 1955, coll. H. A. Fehlmann) with some good reef coralla of this species. In the BMNH No. 27.5.4.128 is a Favia laxa from Port Sudan, Red Sea, that corresponds to the type of Klunzinger. Also Nos. 1956.2.1.1 and 27.5.4.19 from the Red Sea belong to the present species. The last one has on one side corallites with a diameter of $1 \mathrm{~cm}$. Both specimens correspond to the type.

The interpretation of Gardiner, 1904: 775, is not correct; his specimen is probably a Favia pallida. In general, Favia laxa much resembles Plesiastrea versipora (Lamarck, 1816), exactly as Wells remarks of his Favia helianthoides. Because of the several characters typical of Favia, the present species seems for the moment better placed in this genus, although when more material will be collected this position may be changed.

The species is known from: Red Sea, Palau Islands, Marshall Islands, and New Caledonia.

Favites 4) Link, 1807.

Type species. - Favites astrinus = Madrepora abdita Ellis \& Solander, 1786 (by subsequent designation, Vaughan, 1901).

Diagnosis of the genus (after Wells, 1954). Like Favia, but cerioid.

4) Favites is considered to be feminine in gender, in accordance with all later authors, although Link speaks of Favites astrinus.
The following species are here discussed:

- Favites pentagona (Esper, 1794).

Common. Corallites pentagonal or hexagonal, septa not numerous, not very exsert, paliform lobes prominent. Polyp brown with a green stomodaeum.

- Favites melicerum (Ehrenberg, 1834).

Rather common. Calices angular; often a double theca wall is present that causes a slightly plocoid appearance; septa not numerous, paliform lobes prominent. Polyp light green, sometimes with blue or brown spots.

\section{- Favites rufa nov. spec.}

Rare. Corallites capricious in form, theca not well developed, septa not numerous and hardly exsert; inside the shallow fossa the paliform lobes take a characteristic knob-form and are well dentated. The columella consists of twisted septal teeth; the costae are well-developed and intercostal ridges are present. Polyp reddish-brown.

- Favites chinensis (Verrill, 1866).

Rather common. Corallites rounded, theca rather thick; septa numerous, narrow and well dentated; in the fossa a characteristic crown of paliform lobes around the columella. Polyp is light brownish-yellow, often with a light green stomodaeum; sometimes the colour is darker.

- Favites palauensis (Yabe \& Sugiyama, 1936).

Rare. Corallites large (up to $2 \mathrm{~cm}$ diameter), small theca present; septa equally exsert and regularly dentated; paliform lobes broad and well developed, columella consisting of twisted trabeculae; on the coenosteum the costae are continuous. Polyp is light greenish-blue.

- Favites acuticollis (Ortmann, 1889).

Rather rare. Corallites angular; the theca thin, septa falling abruptly into the calice, side irregularly dentated; no or hardly developed paliform lobes; columella seems a continuation of the septal teeth; depth of fossa variable. Polyp brown, mostly with a green stomodaeum.

- Favites abdita (Ellis \& Solander, 1786).

Rather common. Colony often hillocky, corallites angular or round, theca and septa formation variable, septa numerous with irregular strong teeth, the latter forming a paliform structure; new buds formed at the sides of the corallite, sometimes two or three in the same individual; columella fine and dense. Polyp brown with a green stomodaeum. 
- Favites virens (Dana, 1846).

Rather common. Colony spherical or flat, sometimes of a hillocky structure; corallites with a diameter up to 2 to $3 \mathrm{~cm}$, theca and septa variable in structure; dentation well-developed, teeth closely set at the columella. General appearance rough. Polyp brown with greyish-green stomodaeum.

- Favites flexuosa (Dana, 1846).

Rather common. Colony mostly flat or spherical, with characteristically large rounded, flat, well-separated but still cerioid corallites; theca and numerous septa variable in morphology, distinctly dentated, last teeth forming a few rows of paliform lobes; columella of very fine trabeculae; costae on coenosteum not continuous, a groove being visible in between the corallites. Polyp brown, sometimes with a greenish-blue stomodaeum.

Favites pentagona (Esper, 1794). Pl. V figs. 1, 2.

Madrepora pentagona Esper, 1794: 23, pl. XXXIX, lectotype EZI unregistered.

Synonyms. -

Astraea deformis Lamarck, 1816. MNHN.

Prionastrea gibbosissima H. Milne Edwards \& Haime, 1850. MNHN.

Goniastrea rudis H. Milne Edwards \& Haime, 1850. MNHN.

Plesiastrea haeckeli Brüggemann, 1877. ZMB.

Favia adduensis Gardiner, 1904. BMNH No. 27.5.12.91.

Stephanocoenia maldivensis Gardiner, 1904. BMNH No. 27.5.12.34. (Cotype).

*Favites parvicella Nemenzo, 1959. UP No. C-288.

Material. -

New Caledonia collection ZMA (16 colonies):

Biotope 1 - Coel. 5822

" 2 - Coel. $5823-5824$

" 4 - Coel. 5825 - 5826 - 5827

" 6 - Coel. $5828-5829-5830-5831$

$-5832-5833$

" 7 - Coel. 5834 - 5835 - 5836 - 5837.

Other collections:

ZMA Coel. 5851, 5852

PAS. One unregistered specimen Red Sea

\section{Characters. -}

Corallum: The colony is cerioid, mostly flat or encrusting, sometimes hillocky. The calices are pentagonal or hexagonal with an average diameter of $7 \mathrm{~mm}$. The fused walls are usually rather thin, but sometimes thicker; the septa vary in number from 18 to 35 (average 27) and are usually thin and distinctly dentated, the primary
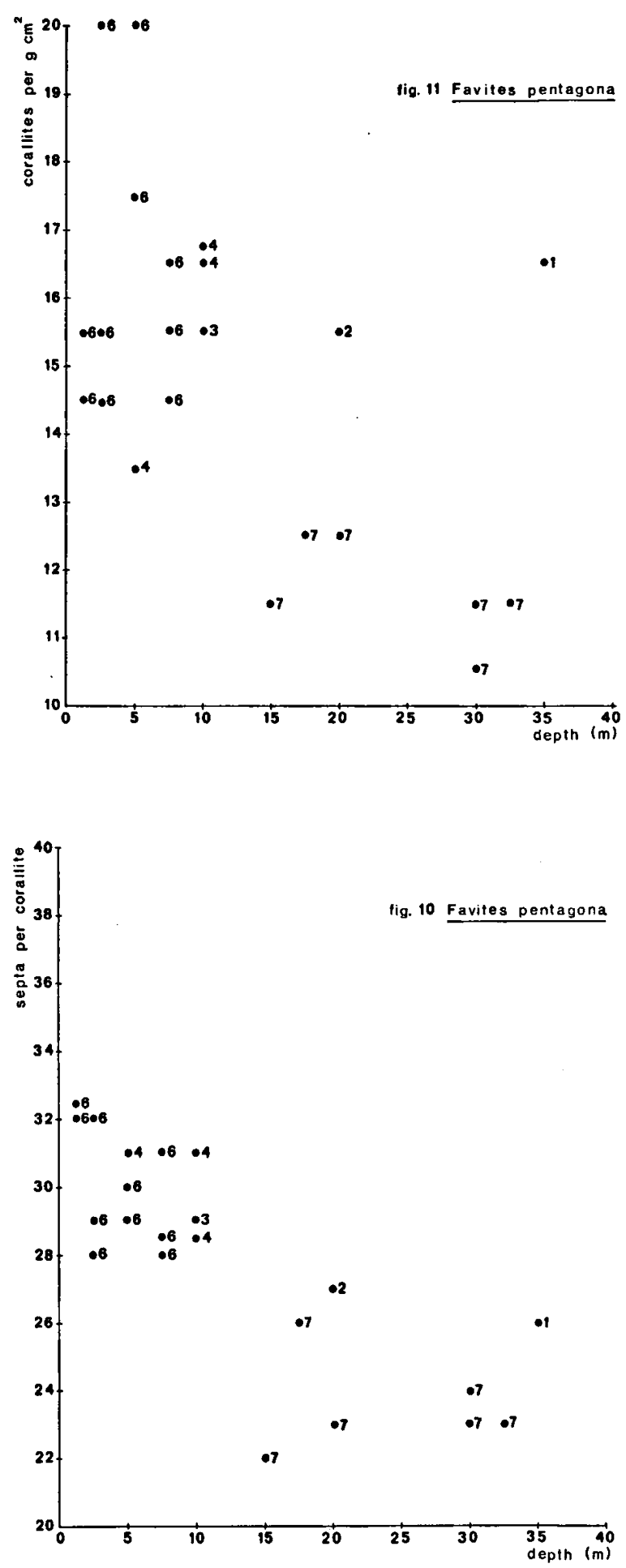

Figs. 10 \& 11. Favites pentagona. Relations between number of septa per corallite and depth of collecting, and between number of corallites per $9 \mathrm{~cm}^{2}$ and depth of collecting.

Numbers indicate the biotopes. 
septa all have a paliform lobe forming together a crown around the fine columella. The species is extremely variable. The specimens from deeper water show a more regular structure, have thinner thecae, shallower calices and more prominent paliform lobes (pentagona growth form).

The polyp is brown with a green stomodaeum. The pentagona specimens are often lighter of colour.

Variability of the characters in the different biotopes. -

For the general environmental influence on variability, I refer to the discussion under Favia favus. In the present species we likewise find a decreasing skeleton deposit in relation to greater depth. The diagrams (figs. 10 \& 11) show this very clearly, and the values found for colonies from the outside of the reef are relatively high for the depth at which they occur, as expected. We may conclude that depth and skeleton deposit are inversely related. All three specimens from biotope 4 can be regarded as reef specimens, and no real lagoon specimens (10 to $20 \mathrm{~m}$ ) have been found. Therefore, it is not surprising that they fall within the range of biotope 6 .

This very variable species is difficult to recognize. The range of variability seen in the holotype of Aphrastrea deformis (Lamarck) is a very instructive one, showing the extreme effects of the differences in the micro-habitats on the corallum. Originally I separated the deformis type from the pentagona form, not only because of skeleton differences but also because of differences in the polyp. The pentagona ecotype occurs in quiet clear water, deformis more in moving turbid water. I still do not exclude the possibility of dealing with two species; but within the available series no real separation could be made. Moreover, the holotype of Aphrastrea deformis shows more or less the pentagona form at the sides of the large corallum.

\section{Discussion. -}

From the description (Esper, 1794: 23) and the good drawing (pl. XXXIX) of the holotype we may conclude that it is an encrusting specimen from a shallow reef habitat. Esper considers Madrepora pentagona a rather common species in the East Indies. The only specimen of the Esper collection that I could find in the Zoological Institute of Erlangen is apparently not the figured type, but certainly belongs to the present species. It must be a paratype and I propose to make it the lectotype. The holotype of Astraea deformis Lamarck, 1816: 264, is a large, light corallum that shows very clearly the variability within one colony due to differences in the microenvironment. At the underside it has the typical shallow, regular pentagonal corallites with the few styliform paliform rods characteristic of pentagona, but the rest of the colony shows more distinctly the irregular habit of deformis. Because of the light structure we assume the specimen to come from deeper water. The holotype of Prionastrea gibbosissima H. Milne Edwards \& Haime, 1850: 133, is a colony from an unknown locality, later on (1857) referred to Favites melicerum by the same authors. The specimen belongs to Favites pentagona and corresponds with some of my fringing reef colonies. The holotype of Goniastrea rudis H. Milne Edwards \& Haime, 1850: 161 , is a large, heavy corallum with small, closely set corallites. The locality is not known, but the specimen probably comes from a shallow reef site, where good conditions for coral growth were present. The holotype of Plesiatrea haeckeli Brüggemann, 1877: 396, is according to Matthai, 1914: 98, similar to Prionastrea melicerum. In my opinion this species is a synonym of Favites pentagona, more particularly of the pentagona ecotype. The species was found in the Red Sea, where this pentagona form is to be expected. The holotype of Favia adduensis Gardiner, 1904: 766, is a colony from the outer slope of the reef of Addu( Laccadives) and corresponds to some degree with the New Caledonian Coel. 5822 in the irregularity and encrusting growth form. The characters resemble so much the deformis form that I regard Favia adduensis as a growth form of the present species. In the same publication Gardiner, 1904: 784, describes a new species, Stephanocoenia maldivensis. He based the description on a few coralla from the Laccadives (Minikoi, Hululu, Addu), that show the pentagona ecotype structure (pl. LXII figs. 29, 30). Matthai, 1914, already considered this species synonymous with Favites pentagona. Favites parvicella Nemenzo, 1959: 97, probably belongs to the present species, although no certainty can be reached because the type has not been re-studied and Nemenzo's photograph (pl. VIII fig. I) is not very clear. According to the description it could be a Favites pentagona, probably from a more exposed facies. Nemenzo was not sure of the status of his new species and stressed its resemblance to the corallum called Favia cf. ehrenbergi Klunzinger by Yabe \& Su- 
giyama, 1936 (pl. XX fig. 3). This last coral corresponds with Coel. 5824, a shallow lagoon form of Favites pentagona. (For Favia ehrenbergi Klunzinger see under Favia favus Forskål).

In other collections some representatives from this species have been found, most of them not very well labelled. One large specimen from the Red Sea, identified by Crossland, is present in the Philadelphia Academy of Sciences. It is a reef specimen corresponding with colonies from biotope 6 . This colony also shows the deeper irregular corallites at the top of the corallum and the shallower, regular (pentagona) corallites at its sides. In the collection of the BMNH many colonies labelled pentagona are present.

Most of them have been identified by Matthai, but he lumped this species with Favites melicerum Ehrenberg and confused both with Goniastrea aspera Verrill. The specimens figured by Yabe \& Sugiyama, 1936, pl. XXIV figs. 1, 2, show the hillocky growth form very well. They correspond with two specimens (Coel. 5851, 5852) present in the ZMA collection, both collected by the Siboga expedition at station 220 (Pasir Pandjang, Binongka, reef exploration).

This species has been reported with certainty from the Red Sea, Maldives, Laccadives, Southern Japan, Indonesian Archipelago, and New Caledonia.

Favites melicerum (Ehrenberg, 1834). Pl. V fig. 3.

*Astraea melicerum Ehrenberg, 1834: 96, holotype ZMB ?

Synonym. -

Goniastrea laxa Quelch, 1886. BMNH No. 1886.12.9. $134-135$.

Material. -

New Caledonia collection ZMA (11 colonies): Biotope 3 - Coel. 5811

$$
\begin{aligned}
& \Rightarrow \quad 4-\text { Coel. } 5812-5813-5814 \\
& \Rightarrow \quad 6-\text { Coel. } 5815-5816-5817-5818 \\
& \quad 7 \text { - } 5819 \\
& \Rightarrow \quad 7 \text { Coel. } 5820-5821 .
\end{aligned}
$$

Other collections:

$\begin{array}{rll}\text { BMNH } & \text { No. 27.5.12.209 } & \text { Ceylon } \\ \text { No. 27.5.12.210 } & \text { Ceylon } \\ \text { No. 27.5.12.215 } & \text { Ceylon. }\end{array}$

Characters. -

Corallum:-The cerioid colony is flat or encrusting. The theca is well developed, sometimes thickened. The septa, varying from 20 to 24, are hardly exsert, the primary ones alternating with very small ones, the sides are irregularly dentated; the last teeth form paliform rods. The columella consists of twisted septal teeth. Characteristic is the "double" wall, caused by the costae ending in a knob-like structure, which, however, cannot always be seen, especially not in coralla from exposed niches.

Polyp: The colour of the polyp is usually light green, sometimes bluish with a brown bloom. The tentacles are extremely long.

Variability of the characters in the different biotopes. -

The present series of this species is not large enough for graphical treatment. Besides, the specimens collected are from 4 different biotopes, all found between 5 and 15 metres. The variation in my series is not large. Specimens from a more exposed niche, e.g. Coel. 5811 from the barrier reef and Coel. 5818 from the fringing reef have a less regular structure, more pronounced teeth formation, and deeper corallites. Most specimens are found in quiet but shallow waters and show the typical melicerum habit. Coel. 5821 from Baie de Prony is a flat colony, strongly built, having the melicerum characters and colour of polyp, but being more plocoid than any other of the specimens, especially in the centre of the colony where the intercorallite ridges can be 5 to $6 \mathrm{~mm}$ wide.

The general trends of adaptation are those found in all other Faviinae.

\section{Discussion. -}

The type specimens could not be traced in the Berlin Museum; however, they are figured by Matthai, 1914, in pl. 36 fig. 4, showing two encrusting colonies on a Lambis shell. My specimens from biotope 4 do correspond with those on Matthai's figure as far as I can judge from the photograph. Goniastrea laxa Quelch, 1886: 102, came from Api (New Hebrides); it is said to be an abundant reef forming species. There are two syntypes present in the British Museum, both reef forms from an exposed niche with more pronounced teeth formation, deeper calices, and smaller corallites.

Vaughan, 1918: 112, recognized this species as valid, though Matthai, 1914, had synonymized it with Favites pentagona. The matter is, however, more complicated. Vaughan based his conclusion on coral pieces (collected by Wood Jones at Cocos Keeling), that resembled a specimen labelled „Favia pentagona” by Matthai, but apparently 
were different. These specimens of Wood Jones are illustrated by Vaughan, 1918, pl. 41 figs. 6, 6a, showing worn coralla that might belong to melicerum. I do agree with Vaughan that Favites pentagona is not always correctly interpreted by Matthai, because three species are involved (see p. 28). For instance, the specimen illustrated by Matthai as Favites pentagona (pl. 24 fig. 3) does not belong to that species, but to the present one. Matthai, however, certainly had seen the type of Favites melicerum Ehrenberg. His decision of considering the two species synonymous seems to have a sounder basis than the application of the name $F$. melicerum by Vaughan to the present biological species.

The latter name may be wrong; the type of $F$. melicerum has to be re-examined first before final conclusions can be drawn. Either the name $F$. melicerum can be applied to the present species, or the name $F$. melicerum is a synonym of $F$. pentagona and the present species has to receive a new name.

The distinction between $F$. pentagona and $F$. melicerum is not always obvious since the variation in the skeleton structures is such that the two often come close to each other, or even overlap. In live, however, they are easily distinguished by the colour of the polyp.

In the BMNH there are three specimens labelled Prionastrea acuticollis Ortmann from Ceylon (27.5.12.209, -210, and -215), not belonging to the species of Ortmann but to the present species. Their habit corresponds to specimens in my series of biotope 6 .

In my opinion the present species may be more common than appears from the paucity of records in literature, chiefly due to confusion about its name and status. Specimens in other collections, however, are rare.

So far, the species has been found in Ceylon, the New Hebrides and New Caledonia.

Favites rufa nov. spec. Pl. VI figs. 1, 2.

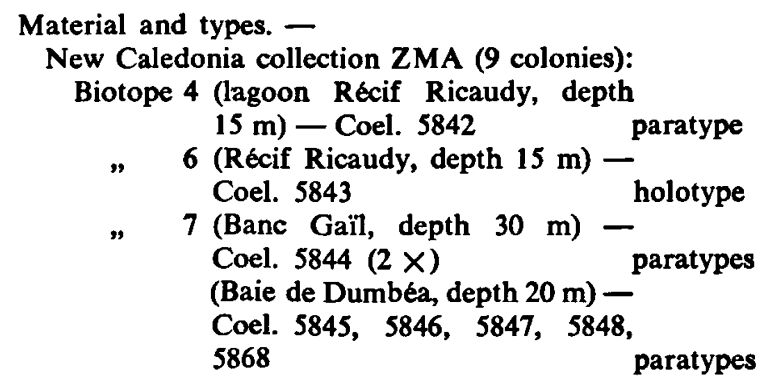

Characters. -

Corallum: The colony is flat or encrusting, the growth is cerioid, although the corallites can be rather widely separated from each other in the growth forms from deeper water. There is a tendency to form branches. The corallites are rounded or angular, sometimes forming short meandroid series. The theca is well developed, varying very much in thickness. The septa are 20 to 30 in number, not exsert but rounded over the theca wall, meeting each other but not fusing. The costae, intercostal ridges and upper septa edges are smooth. A striking character best seen in shallow calices is the well developed, twisted, often even branched teeth formation of the deepest part of the septum and of the columella, giving the corallite a fine lace-like appearance. The paliform rods are knob-like and formed by all septa, so two rows of pali, an inner (of the primary septa) and an outer (of the secondary septa) are often to be seen.

Polyp: The colour of the living animal is reddishpurple, sometimes with green spots (under UV light bright red fluorescent).

Variability of the characters in the different biotopes. -

The present series of this species, from three biotopes only, is not large enough for a detailed discussion or graphic treatment. The lagoon specimen is a small encrusting colony, not different from the bay forms; only the teeth formation on the upper part of the septa and costae is more pronounced. Coel. 5843 shows the characters of the species very well. The colony is very large, at some places forming branches (see pl. VI fig. 1). From the bay facies there are a few specimens collected at a depth of 20 to 30 metres. The corallites are widely separated from each other (up to 15 or $20 \mathrm{~mm}$ ); the calyx is very shallow and the skeleton structure is light.

Although there is not much variability, the trend found is in accordance with the general one.

\section{Discussion. -}

This species is related to Favites pentagona and $F$. melicerum. The main differences from its closest relative $F$. pentagona are the colour of the polyp, the different structure of the paliform lobes and, in similar biotopes, the usually shallower calices. From Favites melicerum it differs also in the colour of the polyps and in a different paliform 
structure; moreover, the "double wall" character never occurs in Favites rufa.

Favites chinensis Verrill, 1866. Pl. V fig. 4.

Prionastrea chinensis Verrill, 1866: 35, holotype YPM No. 1002, paratype MCZ No. 489.

Synonyms. - None.

Material. -

New Caledonia collection ZMA (10 colonies): Biotope 1 - Coel. 5859

" 4 - Coel. 5860

" 6 - Coel. 5861

" 7 - Coel. 5862 - $5863(2 \times)-5864-$ $5865-5866-5867$.

Other collections:

BMNH No. 1892.12.1.399 Moreton Bay (Queensland)

USNM. One unregistered

specimen, leg. Steere Southern Philippines.

Characters. -

Corallum: Colony flattened or encrusting, often showing a hillocky structure. The corallites are rounded (about $10 \mathrm{~mm}$ diameter) with broad walls, giving the colony sometimes a plocoid habit. Characteristic are the equally developed, well dentated septa, all with a paliform lobe at the end. The calyx looks very open and shallow because the numerous septa, varying in number from 28 to 38 (average 32), are not exsert and are continued on the theca wall and coenosteum. The costae do not fuse with each other, and a groove between the corallites adds to the plocoid appearance. Intercostal ridges are often present. The columella consists of fine trabeculae and is round and small.

Polyp: The colour of the living animal is light brownish-yellow with a light green stomodaeum. Sometimes the colour is more intense.

Variability of the characters in the different biotopes. -

Although the series of this species is not large enough to give an extensive discussion on the variability, the same general trend in the growth form as found in larger series can be seen. Coel. 5859 from the outer reef has much stronger teeth formation, and more closely set, deeper corallites, with the number of septa up to 38. Although the septa are not exsert, the teeth formation and slight development of the coenosteum give the corallum an irregular habit. In the lagoon inside the barrier reef, however, we find flat colonies that are regular and much less dentated, while Coel. 5860 from the fringing reef has a hillocky structure with regular, broad and flat corallites on the sides. Most specimens come from quiet lagoon waters where the skeleton structure is much less strong and the corallites are shallow with a broad coenosteum in between. The number of septa decreases down to 28 to 30 . This is the complanata form figured by Yabe \& Sugiyama, 1936, pl. XXI figs. 1,2 .

\section{Discussion. -}

The holotype of the species is from Hongkong, collected by Stimpson and clearly described by Verrill, 1866: 35. The corallum is flat and looks very much like my specimen from biotope 1 . From its characters we may expect that it has been collected in an exposed reef habitat. Another Verrill specimen, MCZ No. 489 (paratype), also from Hongkong, is very much resembling the type.

Later on Yabe \& Sugiyama, 1936: 32, reported this species from Palau Island but under the name Favites complanata (Ehrenberg, 1834). Favites complanata, however, is a completely different species. These are the only literature records I know of. However, in the collection of the BMNH there is a very large colony (1892.12.1.399) from Moreton (Queensland), collected by Saville Kent, and labelled Favia clouei. This is Favites chinensis, probably coming from a shallow fringing reef habitat. In the collection of the USNM a colony without number labelled Favites abdita Ellis \& Solander, 1786, from the southern Phillippines, collected by J. B. Steere, also belongs to the present species, having the habitat of a lagoon ecotype.

Including this new information, the geographical distribution of this rather rare species can be summarized as follows: Hongkong, southern Philippines, Queensland, Palau Island, New Caledonia.

Favites palauensis (Yabe \& Sugiyama, 1936). Pl. VI fig. 3.

*Favia palauensis Yabe \& Sugiyama, 1936: 30, pl. XIX figs. 5 and 6; holotype TIU No. 56631.

Synonyms. - None.

Material. -

New Caledonia collection ZMA (6 colonies):

Biotope 6 - Coel. 5777

" 7 - Coel. 5772 - 5773 - 5774 - 5775 5776. 
Characters. -

Corallum: The colony is cerioid with large rounded polygonal corallites (diameter up to $20 \mathrm{~mm}$ ). The theca is well developed, and in the bay forms the intercalicular wall can be so wide that the corallum has a plocoid appearance. The septa are regular, equally exsert and well dentated, the number varies from 25 to 50 . In the "plocoid" colonies the costae present on the intercalicular wall are thin and do not always continue from one corallite to the other. All primary septa have a well developed paliform lobe, a character that distinguishes this species from the other Favites species. The columella consists of fine trabeculae.

Polyp: The colour of the living animal is light greenish blue.

Variability of the characters in the different biotopes. -

Representatives of this species have been found in sheltered environments only. The species is not common, and is very easily recognized alive. Since I have not found it in more exposed niches, the species may be stenotopic. Coel. 5777 from the fringing reef is cerioid and strongly built; the average number of septa is 50 . The specimens from Banc Gaïl, however, show more pronouncedly the "plocoid" structure found in the type of Yabe \& Sugiyama (1936, pl. XIX figs. 5, 6). Deeper water ecotypes have in general large, shallow corallites, rather widely separated from each other, and a light colony structure. Coel. 5772 comes from an environment with heavy sedimentation (Baie de Dumbéa, depth $14 \mathrm{~m}$ ). The colony is extremely light with fewer septa (25), the calyx is shallow, and the polyps are large with long tentacles. These pecularities show an adaptation to sedimentation: quick growth, shallow calices and large polyps facilitating better removal of sediment.

\section{Discussion. -}

The holotype (Yabe \& Sugiyama, 1936: 30 ) is from Palau. The authors do not say anything about the habitat, but I presume that the figured type specimen comes from a sheltered (deep) site. The resulting ecotype, a plocoid colony, lead Yabe \& Sugiyama to include it in Favia. As explained above, the plocoid ecotype structure is in reality cerioid, also because of the intratencular budding through marginal fission. The species is better placed in the genus Favites.

In other collections I did not come across specimens belonging to the present species, which at the moment is only known from Palau and New Caledonia.

Favites acuticollis (Ortmann, 1889). PI. VI fig. 4.

Prionastrea acuticollis Ortmann, 1889: 528, pl.XVI fig. 11, holotype ZMB no. 4793.

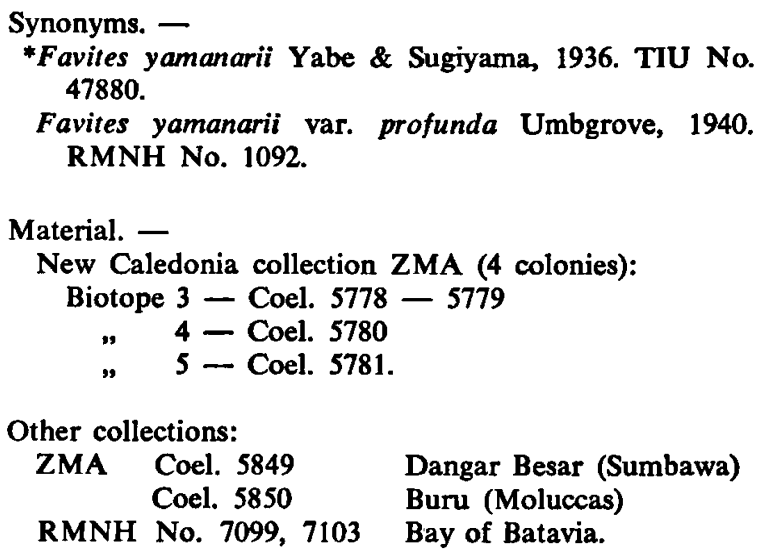

Characters. -

Corallum: The colony is spherical to flat, and cerioid. The theca is thin even in deeper water growth forms. The septa vary from 25 to 40 in number and are regularly built, neither exsert nor dentated. The teeth present on the edge of the septa are of equal length and give the corallum a spiny habit. In the deeper corallites (usually from a shallower biotope) no palial structure is present, the columella is round and consists of twisted septal teeth. In shallower corallites (from a deeper or more sheltered habitat) the last septal teeth form paliform lobes.

Polyp: The colour of the living animal is brown with a green stomodaeum.

Variability of the characters in the different biotopes. -

With four colonies present, it can only be said that the differences between the lagoon and reef ecotype are in accordance with the general environmental influences on the morphology found in the Faviinae. The two colonies from the inner barrier reef (Coel. 5778, 5779) are rather strongly built, irregular, and show a stronger teeth formation than the specimens from the lagoon or fringing reef. Coel. 5781 from Ile de l'Arrenière resembles the barrier reef specimens in having deep corallites, numerous septa (about 40), no paliform lobes, and heavy structure. The corallum is more regular and the teeth formation less strong, how- 
ever. The flattened corallum from the lagoon has less septa (about 30), shallow calices and a paliform lobe structure.

\section{Discussion. -}

The holotype (Ortmann, 1889: 528) is from Ceylon, and probably a specimen from a reef site. The regular dentation made Ortmann remark that the species resembled Prionastrea spinosa Klunzinger (now included in the genus Acanthastrea, Mussidae).

Favites yamanarii Yabe \& Sugiyama, 1936: 33, is very well illustrated (pl. XIX fig. 10) and corresponds in most respects with the specimen of Ortmann. The first, however, has shallow calices and a more or less distinct palial structure; therefore, one can expect that the specimen from Japan (KitaDaito-zima) comes from a deeper or more sheltered site. The type of Favites yamanarii var. profunda Umbgrove, 1940: 31 , is a reef specimen with deep calices (up to $8 \mathrm{~mm}$ ), hardly a paliform structure, numerous septa (up to 40), and is strongly built. Umbgrove summarizes the differences between his var. profunda and var. typica of Yabe \& Sugiyama. The last one has no complete cycle of rudimentary septa, has thicker intercalicular walls and has shallower calices. I agree with his observations but in my opinion these characters depend on environmental factors. The two specimens, Coel. 5850 from Leksoela, Buru, leg. Toxopeus, and Coel. 5849 from Siboga station 313 (Danger Besar, reef exploration, depth up to 36 $\mathrm{m})$ present in the ZMA are both from a shallow reef habitat, corresponding with Umbgrove's var. profunda in most respects.

This species resembles so closely a typical Goniastrea, that for a long time I thought my specimens belonged to Goniastrea aspera Verrill. After examining the type of G. aspera (MCZ No. 406) I can only conclude that the latter is a real Goniastrea species, and not a species of Favites as supposed by Umbgrove (1940: 30). Under Goniastrea favulus (Dana) I shall refer to this species again.

Favites acuticollis is at the present known from Ceylon, Indonesian Archipelago, Japan, and New Caledonia.

Favites abdita (Ellis \& Solander, 1786). Pl. VII figs. 1, 2.

Madrepora abdita Ellis \& Solander, 1786: 162, pl. 50 fig. 2, holotype Gl.
Synonyms. -

*Favastrea magnifica de Blainville, 1830. MNHN ?

*Astraea fusco-viridis Quoy \& Gaimard, 1833. MNHN ?

Astraea hemprichii Ehrenberg, 1834. ZMB No. 746.

* Astraea halicora Ehrenberg, 1834. ZMB No. 733.

Astraea robusta Dana, 1846. USNM No. 63.

Prionastrea obtusata H. Milne Edwards \& Haime, 1850. MNHN.

* Prionastrea quoyi H. Milne Edwards \& Haime, 1850. MNHN ?

*Prionastrea sulfurea H. Milne Edwards \& Haime, 1850. MNHN ?

* Prionastrea profundicella H. Milne Edwards \& Haime, 1850. MNHN?

Prionastrea crassior H. Milne Edwards \& Haime, 1850. MNHN.

Prionastrea seychellensis H. Milne Edwards \& Haime, 1850. MNHN.

* Prionastrea gibbosa Klunzinger, 1879. ZMB ?

Material. -

New Caledonia collection ZMA (7 colonies):

Biotope 1 - Coel. 5800

" 2 - Coel. 5799

" 3 - Coel. 5801

$" 4-$ Coel. 5803

" 6 - Coel. $5802-5804-5805$.

Other collections:

ZMA Coel. 5806 Ambon (Moluccas)

Coel. 5807 Dangar Besar (Sumbawa)

Coel. 5808 Singapore

Coel. 5966, 5968 Saleyer (Java Sea)

Coel. 5967 Haingsisi (Timor)

Coel. 5969 Seget (western New

Guinea)

RMNH 1081, 1082, 1085, 1086, Togian Reef (Celebes) 1096

BMNH No. 28.9.1.282 Red Sea

No. 1895.109.101 King Sound (Great Barrier Reef)

No. 1934.514.105 Great Barrier Reef

Characters. -

Corallum: The colony is spherical or flat, often forming a hillocky structure (abdita form). The corallites are extremely variable, the diameters ranging from 5 to $15 \mathrm{~mm}$, and the depth of the calice from a few $\mathrm{mm}$ up to $10 \mathrm{~mm}$. The theca wall can be very thin, especially in the corallites on top of the hillocks, or 4 to $5 \mathrm{~mm}$ thick (robusta form). The number of septa varies between 20 and 50. Well developed teeth formation is present all over the septum edge. Especially in specimens from more exposed habitats the dentation can resemble that of an Acanthastrea (halicora form). The teeth continue on the edge of the corallite and in between the corallite walls. Intercostal and septal ridges are present.

A paliform structure can hardly be seen. The 
columella is round and consists of fine trabeculae. It is difficult to give a more accurate description of this very variable species.

Polyp: The colour of the living animal is brown, often with a green stomodaeum.

Variability of the characters in the different biotopes. -

The high degree of adaptability may have helped the species to become very widespread. It is rather common on the New Caledonian reefs, where it can form very large coral heads which are difficult to collect properly. Therefore, the collection made is not large enough for graphical treatment, but the variation within the series will be discussed. On the outer reef (biotope 1), the corallum is of the typical flat habit of the halicora ecotype, with in the shallow calices about 30 well developed septa with strong dentation. Coel. 5800 from a depth of about $20 \mathrm{~m}$ shows the thick robusta form and deeper corallites with about 40 septa, with long and irregularly dentated edges. All specimens from the inner reef area have smaller corallites and are more distinctly the abdita ecotype with a hillocky structure. The two specimens from biotope 4 were both found in a shallow lagoon and resemble those from the fringing reef. In addition to having a hillocky structure, the corallites are small. The calyx is rather deep, and the septa are numerous (average number 40). A paliform structure is hardly developed.

\section{Discussion. -}

The holotype (Ellis \& Solander, 1786: 62) is a specimen with a hillocky habit and rather worn corallites, the teeth formation is hardly visible. The corallite walls can be rather high (resembling in this respect Prionastrea seychellensis H. Milne Edwards \& Haime). The locality is unknown but I suppose that the specimen comes from a rather quiet, sheltered habitat. The types of the following species ought to be present in Paris, but could not be traced: Favastrea magnifica de Blainville, 1830: 340; Astraea fusco-viridis Quoy \& Gaimard, 1833: 215; Prionastrea quoyi H. Milne Edwards \& Haime, 1850: 130; Prionastrea sulfurea H. Milne Edwards \& Haime, 1850: 130, and Prionastrea profundior $\mathrm{H}$. Milne Edwards \& Haime, 1850: 131. These species were already synonymized with Favites abdita by Matthai in 1914. Judging from the original description and figures, I can fully agree with Matthai's views. The holotype of Astraea halicora Ehrenberg, 1834: 97. from the Red Sea cannot be traced. According to Matthai, 1914, the specimen figured by Klunzinger, 1879 , on pl. IV fig. 1 is Ehrenberg's type. It resembles the flat corallum from my outer reef series. The resemblance between Acanthastrea hemprichii (Ehrenberg, 1834) and Astraea halicora was already mentioned by Umbgrove, 1940: 280 . After having seen the holotype of Acanthastrea hemprichii, from the Red Sea, I conclude that it lacks the typical dentation normally found in Acanthastrea, the genus to which hemprichii is generally referred to. The holotype of Astraea robusta Dana, 1846: 248, comes from the Fiji Islands and is a big hillocky colony, strongly built with well developed teeth on the septal edges. It belongs to the present species. The holotype of Prionastrea obtusata H. Milne Edwards \& Haime, 1850: 130, from Tongatabu has more pronouncedly the halicora appearance, having thick walls with a strong dentation. The holotype of Prionastrea crassior H. Milne Edwards \& Haime, 1850: 131, from an unknown locality resembles Dana's Astraea robusta. It has the thick theca walls of robusta and the flat morphology of halicora at the side, but many characters of abdita on top of the corallum. The holotype of Prionastrea seychellensis $\mathrm{H}$. Milne Edwards \& Haime, 1850: 132, has extremely long and thin theca walls. It comes from the Sechelles and is probably a growth form of the present species. The holotype of Prionastrea gibbosa Klunzinger, 1879: 40, is illustrated by the author (pl. IV fig. 10). I agree with Matthai, 1914: 93 , in considering it a synonym of the present species.

In literature most publications dealing with Favites abdita and $F$. halicora mention the variability of both species and/or their close resemblance. Matthai (1914: 92) divides Favites abdita in two growth forms: the abdita and the more strongly built fusco-viridis form, of which the latter in my opinion is transitional between the two ecotypes abdita and halicora. Vaughan (1918) stated that "some spocimens of Favites halicora have a most perplexing resemblance to some specimens of Favites abdita", but concludes that the teeth formation in halicora is characteristic for the latter species. Hoffmeister (1925) remarked that in general abdita can be separated from halicora by the shallower calices, hillocky structure and more gentle sloping septa, which are, in my opinion, adaptive characters.

The New Caledonia series of this species is not large enough for a definite decision whether abdita 
and halicora are mere growth forms of one species. There are, however, many specimens present in other collections of this common and widely distributed species, that give a better idea about the amount of variation. In view of all these data I conclude that there is only one species, that should be called Favites abdita. $F$. halicora, with the rounded or flattened corallum and stronger teeth formation, is merely a growth form of a more exposed habitat. Of the specimens of Umbgrove $(1939,1940)$ which I have studied and of which the habitat is well indicated, all halicora forms (Nos. 1094, 1095, 1096) come from the outer reef, most abdita forms (Nos. 1081, 1082, 1083, 1084) from a more sheltered habitat. The many specimens present in the BNMH collection, not always well labelled, show a very large degree of variation.

No. 1895.10.9.101 from King Sound, collected by Saville Kent called abdita by Matthai, has all characters of a halicora. No. 28.9.1.282, called Prionastrea seychellensis was collected in the Red Sea. The thecae of this specimen are very high (up to $15 \mathrm{~mm}$ ) but it may be a growth form of the present species, probably from a quiet, shallow habitat. No. 1934.5.14.105 from the Great Barrier Reef is a reef form that shows the halicora growth form on top and the abdita form at the sides. ZMA Coel. 5808 is a specimen from Singapore, showing a hillocky habit and further characters of abdita. Coel. 5806 from Siboga station 231 (Ambon, reef exploration, coral sand, depth up to $40 \mathrm{~m}$ ) is a transitional form with a flattened corallum, but with a tendency to form hillocks, thin abdita-like theca, and shallower halicora calices which are fairly dentated. ZMA Coel. 5807, from Siboga station 313 (Danger Besar, reef sand and mud, depth up to $36 \mathrm{~m}$ ), shows the halicora growth form.

In general it can be said that the growth forms are the result of environmental factors and correspond with the general trend as seen in other Faviinae. The present species, however, is so plastic that both the extremes may already be seen within one large colony; the hillocky thinly walled abdita as branches on a stronger base that resembles halicora. It is not surprising that so many names are present in literature for this species. This species could be a very convenient one to use for experimental testing of the fluctuations in growth that are influenced by some micro-environmental factors. I shall refer to this problem again in the chapter on the general ecology.
The species occurs in the Red Sea, the Indian Ocean, and is widely distributed in the Pacific as far East as Samoa.

Favites virens (Dana, 1846). PI. VII figs. 1, 2.

Astraea (Fissicella) virens Dana, 1846: 228, pl. 11 fig. 8; holotype USNM No. 26.

Synonyms. 78.

Prionastrea magnistellata H. Milne Edwards \& Haime, 1850. MNHN.

Prionastrea vasta Klunzinger, 1879. MNHN?.

*Prionastrea vasta var. superficialis Klunzinger, 1879. ?

*Favites ellisiana Verrill, 1901 ( = Madrepora favosa Ellis \& Solander, 1786, non Madrepora favosa Linnaeus, 1758). Gl. lost.

Material. -

New Caledonia collection ZMA (10 colonies):

Biotope 1 - Coel. 5788

" 2 - Coel. $5789-5790-5791(2 \times)-$ 5792

" 3 - Coel. 5793

" 4 - Coel. $5794-5795$

" 6 - Coel. 5796.

Other collections:

ZMA Coel. 322 Japan

Coel. 1742

RMNH No. 1090, 1091

BMNH No. 1934.5.14.109

Nosy Bé (Madagascar)

Celebes (Togian Bay)

Great Barrier Reef.

Characters. --

Corallum: The colony is spherical or flat, sometimes having a hillocky appearance. Just as Favites $a b d i t a$, the species is a very variable one. Reproduction is by marginal fission. The corallites vary from 10 to $25 \mathrm{~mm}$, the depth of the calyx from 5 to $15 \mathrm{~mm}$. The theca is well developed and may be thickened up to $5 \mathrm{~mm}$. The number of septa varies from 30 to 60 . Teeth are well developed, and present along the whole of the side of the septa and costae. A paliform lobe structure is hardly present. The columella is round and consists of twisted fine trabeculae.

Polyp: The colour of the living animal is brown with a green stomodaeum.

Variability of the characters in the different biotopes. -

The pattern of variation shown in my series has a striking resemblance to the one seen in Favites abdita. The outer reef coralla have large (up to $25 \mathrm{~mm}$ ), rather shallow calices (becoming smaller and deeper in shallower waters) and numerous 
well developed septa with a strong dentation. Coel. 5788 resembles the vasta ecotype; the more rounded corallum, Coel. 5791, looks like the form ellisiana as pictured by Ellis \& Solander, 1786 (pl. 50 fig. 1). Inside the barrier reef, the coralla have slightly smaller corallites (virens ecotype) but are in general less strongly built. Their growth form sometimes has a hillocky appearance, e.g. Coel. 5796. The teeth formation remains extensive but the teeth are thinner, a spinose habit.

\section{Discussion. -}

The holotype of Astraea virens (Dana, 1846: 228) from the Fiji Islands is a flattened corallum with regular and small calices. It resembles my Coel. 5793 from inside the reef. Vaughan remarks that Matthai's figure of Favites halicora (pl. IV fig. 2) is similar to the virens ecotype. I agree with his statement. The holotype of Favites ellisiana ( $=F$. favosa sensu Ellis \& Solander, 1786: 167) is figured (pl. 50 fig. 1) by the latter authors, but the specimen itself is lost. Already Matthai (1914) could not trace it. The corallum is spherical, the corallites are large (about $20 \mathrm{~mm}$ diameter); because there is no sign of a hillocky structure this specimen probably came from an exposed reef site. Prionastrea magnistellata $\mathrm{H}$. Milne Edwards \& Haime, 1850: 129, is an ecotype of this species corresponding to ellisiana. The holotype of Astraea filicosa Dana, 1846: 232 from Wake Island belongs to the present species but is a worn specimen. The holotype of Prionastrea vasta Klunzinger, 1879: 38, could not be traced in Berlin. In the NMNH a corallum of Klunzinger is present, which probably is the type of Prionastrea vasta as figured by him (1879, pl. IV fig. 12). Klunzinger's var. superficialis (pl. IV fig. 8) corresponds to my outer reef corallum from below $20 \mathrm{~m}$.

In the literature many different opinions are current about this species (e.g. Klunzinger, 1879; Gardiner, 1904; Matthai, 1914; Vaughan, 1918; Yabe \& Sugiyama, 1936; Crossland, 1952). Some of the views I have already mentioned, as far as they shed some more light on the problem of how far the variation of this species may extend. Favites flexuosa Dana, 1846, is often involved in the discussion, e.g. by Crossland, 1952: 130. Although $F$. flexuosa belongs to the same group as $F$. abdita and $F$. virens, I regard it as a separate species. The holotype of Favia complanata Ehrenberg, 1834: 93, ZMB No. 695, belongs to the genus Favites, being very similar to the presently discussed group of species. Possibly it is a synonym of the present species, being a virens ecotype, but its teeth formation is much stronger and it does not resemble any corallum of my series. According to Matthai, 1914: 109, ${ }^{*} F$. tessifera (Ehrenberg, 1834 ), is a synonym of $F$. complanata.

In the BMNH there is a large collection of this species, but most of them are insufficiently labelled. No. 1934.5.14.109 is a specimen from the Great Barrier Reef, identified by Crossland and resembling my specimen Coel. 5788. The coenosteum is rather wide, so the colony has the appearance of a Favia. For other specimens of Crossland's series, see under the next species, although $I$ include all of them in Favites virens. Of Umbgrove's (1939) specimens, No. 1090 from Togian Bay is labelled Favites favosa. It is a reef colony with large corallites of the ellisiana ecotype. No. 1091, identified as Favites virens, has large corallites and less septal dentations, shows the virens ecotype. ZMA Coel. 1742 (Pointe de la Fièvre, Nosy Bé, Madagascar) resembles Coel. 5791, both from a reef site, showing the ellisiana ecotype.

The present species occurs in the Red Sea, Madagascar, Chagos, Indonesian Archipelago, Japan, Wake Island, Murray Island, Great Barrier Reef, New Caledonia.

Favites flexuosa Dana, 1846. Pl. VIII figs. 1, 2.

Astraea flexuosa Dana, 1846: 227; holotype USNM No. 27.

Synonyms. - None.

Material. -

New Caledonia collection ZMA (7 colonies):

Biotope 1 - Coel. 5782 - 5783

" 2 - Coel. 5785 - 5798

" 3 - Coel. 5784

" 4 - Coel. 5786

" 6 - Coel. 5787

Other collections:

RMNH No. 1088, 1089 Togian Reef (Celebes)

Characters. -

Corallum: The colony is spherical or flat and sometimes has a hillocky appearance. The corallites are rounded, due to thickened theca walls that give the colony a plocoid appearance. The diameter of the corallites varies from 10 to $20 \mathrm{~mm}$. The septa are numerous with an average of 40 , they are equally exsert, rounded on the theca wall and continuing as costae in between the corallites 
(intercostal ridges are present). Their edges are regular and strongly dentated, the last few teeth down in the calyx forming a characteristic circle of paliform lobes. The columella is round and consists of twisted fine trabeculae. The reproduction is by marginal fission.

Polyp: The colour of the living animal is brown, the stomodaeum sometimes greenish-blue.

Variability of the characters in the different biotopes. -

The variation shown in my series is in accordance with the general trend found in the Faviinae. The outer reef colonies from below 20 $\mathrm{m}$ are flat, strongly built, and with rather widely separated corallites. The much more irregularly built colonies from a more shallow outer reef site are rounded or slightly hillocky. They have the corallites more closely set and stronger teeth on the septa and costae. Coel. 5786 from the lagoon is a flat colony with shallow, large corallites. Coel. 5787 from a shallow fringing reef habitat shows very well that a hillocky structure can also be found in the present species. The corallites of this specimen are smaller and deeper, but the flexuosa characters remain visible.

\section{Discussion. -}

Dana's holotype is a large specimen from the Fiji Islands. It resembles my specimens from biotope 2 but is more regular in structure.

The literature about the present species is very controversial. Vaughan (1918: 109) regards Favites flexuosa as a synonym of $F$. abdita. In 1936: 32 , Yabe \& Sugiyama held the opposite opinion, and separated the two species again. Umbgrove (1940: 29) agrees with Yabe \& Sugiyama, basing his opinion on specimens from the Togian Reef and the Bay of Batavia that corresponded with the Palau material of the Japanese workers. Crossland, 1954: 130, synonymizes the present species with Favites virens, while Nemenzo, 1959: 95, separates them again.

In other collections the present species is rare, and when present, the material is not sufficiently labelled to be used in the present study. Crossland claims to have demonstrated in his series a complete continuity from virens to flexuosa. However, specimens from the same habitat only should be compared. In my series a gap between the two species is apparent when the specimens originate from the same biotope. Of Crossland's seven specimens, which I have re-studied in the BMNH, one is Favia favus (No. 145); and No. 167 is F. abdita (halicora form). Of the rest, No. 114 really resembles $F$. flexuosa but even this specimen I include in $F$. virens. At any rate this series (without further ecological data) cannot shed light on the present species problem.

I never had much difficulty in identifying Favites flexuosa. The species comes indeed very close to $F$. abdita (halicora) and $F$. virens (virens), but since $I$ have recognized the present species in different biotopes I think that it is not a mere growth form of virens, its closest relative. According to our present knowledge the species can best be regarded as another sibling species in the complex abdita-virens-flexuosa-complanata.

Favites flexuosa has been found in the Indonesian Archipelago, Palau, the Great Barrier Reef, New Caledonia, and the Fiji Islands.

\section{Goniastrea H. Milne Edwards \& Haime, 1848.}

Type species. - Astraea retiformis Lamarck, 1816 by subsequent designation: H. Milne Edwards \& Haime, 1849: 495 .

Diagnosis of the genus (after Wells, 1954). -

Cerioid or submeandroid; colony formation by monostomodaeal to tristomodaeal budding, corallites permanently monocentric. Septa with scarcely dentate paliform lobes. Columella feeble.

The following species are discussed:

- Goniastrea retiformis (Lamarck, 1816).

Rare. Corallites small with an average diameter of $4 \mathrm{~mm}$. Theca generally thin, but sometimes thickened. Septa regular, average number 25, equally exsert, with flat paliform lobes. Columella small and fine. Polyp light brown.

- Goniastrea spectabilis (Verrill, 1872).

Rather common. Resembles $G$. retiformis, but with larger corallites (average diameter $8 \mathrm{~mm}$ ). Theca thin, sometimes thickened; septa very regular and equally exsert; a small crown of paliform lobes present at the calyx floor. Columella fine. Polyp greyish-brown.

- Goniastrea favulus (Dana, 1846).

Rare. Corallites mostly monocentric; sometimes short meanders present; average diameter of the valleys $5 \mathrm{~mm}$. Theca thin, the numerous thin septa finely dentated; only the primary septa forming well developed styliform rods. Columella consisting 
of loosely twisted trabeculae. Polyp brownishgreen.

- Goniastrea pectinata (Ehrenberg, 1834).

Common. Corallites often polycentric, but the meanders usually not very long; average width of the valley $6 \mathrm{~mm}$. Theca thin, septa hardly exsert. Septa falling abruptly and deeply into the calyx, the edge regularly dentate; paliform lobes well developed. Columella consisting of fine, twisted trabeculae. Polyp brownish-purple with a greenishgrey stomodaeum.

- Goniastrea australensis (H. Milne Edwards \& Haime, 1857).

Common. Corallites often polycentric, forming rather long meanders; average diameter $8 \mathrm{~mm}$. Theca thin, septa hardly exsert. Specially characterized by the strongly developed paliform lobes in front of all septa. Columella consisting of fine trabeculae. Polyp light yellowish-brown, with a bluish-green stomodaeum.

Goniastrea retiformis (Lamarck, 1816). Pl. VIII fig. 3.

Astraea retiformis Lamarck, 1816: 265; holotype MNHN.

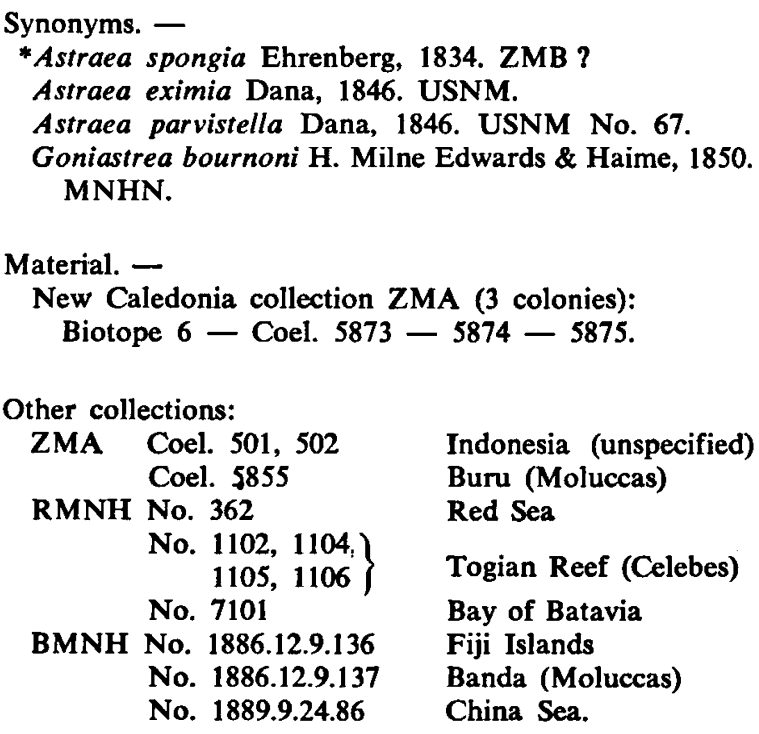

Characters. -

Corallum: The colony is cerioid, sometimes forming short meanders (dicentric of tricentric). The corallites are small, with an average diameter of $4 \mathrm{~mm}$. The thecae are very thin but may be thickened; the thin and regularly formed septa are hardly exsert. At the upper part of the calyx their margin is horizontal; then they fall abruptly down into the calyx. The primary ones all form a flattened paliform lobe; the columella is small and consists of fine trabeculae. The depth of the calyx is variable.

Polyp: The colour of the living animal is light brown.

Variability of the characters in the different biotopes. -

Because from New Caledonia I have representatives from the fringing reef only, not much can be said about the variability in different biotopes. However, this widespread and adaptive species is well-known in the literature for its variability. Within one colony the corallites can range from shallow with thickened thecae to deep with thin thecae. The controversy existing about this species will be discussed below.

Discussion. -

The holotype of Astraea retiformis from an unknown locality, is a massive corallum, corresponding with the description given. The holotype of Astraea spongia Ehrenberg, 1834: 96, could not be found in the ZMB. Matthai, 1914: 118, has studied the specimen and agreed with Klunzinger in that it is synonymous with Goniastrea retiformis. What is probably the holotype of As. traea eximia Dana, 1846: 242, is a worn specimen without a registration number (Vaughan, 1918: 114, said the type was lost). The worn specimen belongs to Goniastrea retiformis, an identification which is confirmed by Dana's description. The holotype of Astraea parvistella Dana, 1846: 244, from the Fiji Islands, is a strongly built encrusting specimen. The variation within the colony is great, just as in Coel. 5873. The holotype of Goniastrea bournoni $\mathrm{H}$. Milne Edwards \& Haime, 1850: 162 , is present in the MNHN and belongs to Goniastrea retiformis.

The nomenclatorial history of this species and most of its synonyms has been summarized by Crossland, 1952: 134, to whom I refer for further details. Concerning the species delimitation the following can be said. This species of Goniastrea with its small corallites is often split into two species, Goniastrea retiformis s.s. and Goniastrea parvistella (= Goniastrea solida sensu Matthai, 1914), e.g. by Vaughan, 1918: 114; Yabe \& Sugiyama, 1936: 34; Nemenzo, 1959: 98; Foidart, 1970. 
Other students, viz. Faustino, 1959: 139, and Crossland, 1952: 133, follow the opinion of Hoffmeister, 1925: 26, who concludes that the main difference between these species is in the thickness of the walls. My series is too small to give a good impression of the variability. But Coel. 5873 shows at the sides of the corallum more distinctly the parvistella form with the shallower, thickened corallites and a clear paliform structure, and on top the retiformis form with the deeper, thinner corallites and a less developed paliform structure. Transitional forms between the two extremes can be seen within one colony as already stated. Umbgrove's, specimen, RMNH 1106 shows both the forms in one colony, while No. $1104 \& 1105$ show the retiformis-type only, and No. 1102 the parvistella-type.

The collection of Matthai-Gardiner present in the BMNH from various localities, e.g. the Red Sea, Seychelles, Singapore, Great Barrier Reef, Maldives, and the collection of Hoffmeister in the USNM together with the spocimens mentioned under "material" give me the impression of dealing with one species with two ecotypes: retiformis from a more exposed site and parvistella from a more sheltered one. This impression cannot be verified for lack of detailed habitat information, but is, I think, supported by the general relation between skeleton deposit and depth found in other Faviinae.

The specialized study of Foidart, 1970, about this particular problem, goes into many details about the skeleton differences between the two forms. It is my opinion that such detailed morphological studies are not efficient in these extremely adaptive animals. Either a detailed physiological study has to be carried out, or one must collect a large series, to find the relation between the morphological adaptations and environment. At the moment I prefer to regard retiformis and parvistella as one species with at least two ecotypes.

Localities from which the species is known are: the Res Sea, Maldives (Gardiner, 1904: 772), Singapore, Indonesian Archipelago, Philippines, Great Barrier Reef, New Caledonia, Marshall Islands, Fiji Islands, and Samoa.
Goniastrea spectabilis (Verrill, 1872). Pl. VIII fig. 4.

Prionastrea spectabilis Verrill, 1872: $381=$ Astraea (Fissicella) magnifica Dana, 1846: 231, pl. 12 fig. 3, holotype USNM No. 79.

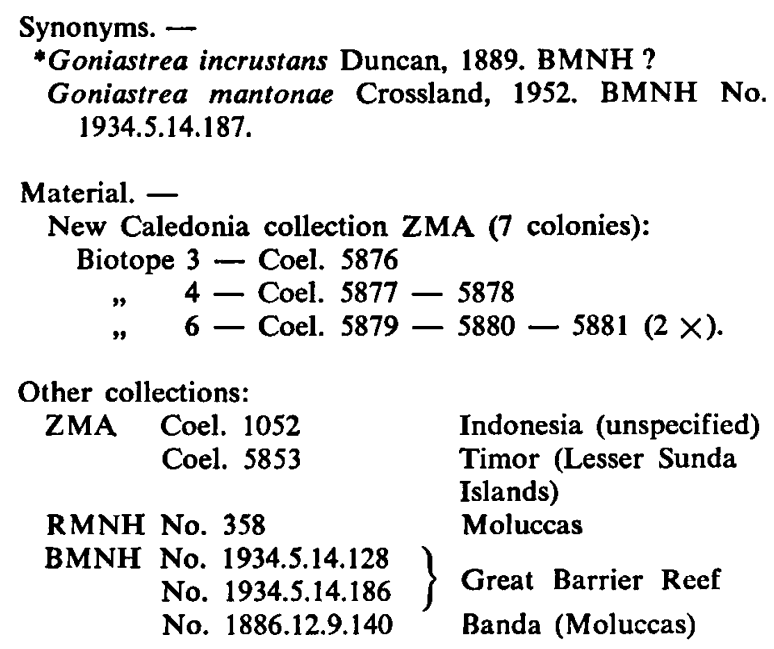

Characters. -

Corallum: The colony has a spherical or flattened form, and is cerioid or slightly meandroid. The asexual reproduction is by marginal fission; the corallites are polygonal; their average diameter is $7 \mathrm{~mm}$. The thecae are thin, sometimes thickened, the septa (about 7 per $5 \mathrm{~mm}$ ) not exsert and regular in structure and dentation. All septa have a pointed paliform lobe forming a regular crown around the small columella, the latter consisting of fine trabeculae. The general habit is a very regular one.

Polyp: The colour of the living animal is brownish-grey.

Variability of the characters in the different biotopes. -

The series present of this species is neither large not representative enough for graphical treatment. The specimen from the shallow inner barrier reef has thin thecae and deep calices, and the relatively irregular habit may be due to an extremely active marginal fission. Of the two small colonies from biotope 4, one (Coel. 5877) from a shallow, sandy spot has a very regular structure; the other (Coel. 5878) from a less sheltered shallow site has thicker thecae and a more irregular structure. Two of the colonies from a depth of $10 \mathrm{~m}$ in biotope 6 (Coel. 5881, 2x) resemble Goniastrea mantonae Crossland, 1952, pl. VII figs. 1 and 2. Coel. 5879 
and Coel. 5880, likewise from biotope 6, have stronger thecae and deeper calices. The variation in my series is not great, because all specimens come from sites inside the barrier reef and from a depth of $10 \mathrm{~m}$ or less.

\section{Discussion. -}

The holotype of the present species was figured and redescribed by Vaughan, 1918: 113, and came from the East Indies. The colony tends more to meandering than any of my specimens, and has wider corallites. The holotype of Goniastrea incrustans Duncan, 1889: 11, could not be traced in the BMNH, but is clearly described and figured by Duncan and should be regarded synonymous with Goniastrea spectabilis. It has been found in the Mergui Archipelago. Goniastrea mantonae Crossland, 1952: 136, is based on three colonies, BMNH Nos. 1934.5.14.128, 1934.5.14.186, and 1934.5.14.187 from the Great Barrier Reef which belong to the present species.

It is not difficult to see why the species was described as a Favites, because the tendency to meander is not always visible. But in view of other characters (thin thecae, well developed paliform lobes) it is better to include it in the genus Goniastrea. Authors such as Vaughan, 1918, Faustino, 1927, and Umbgrove, 1940, stressed the resemblance to Goniastrea. Other specimens of Goniastrea spectabilis studied are some colonies from the Indonesian Archipelago. ZMA Coel. 5833 from Siboga station 296 (Noimini, Timor, reef, depth 8 to $36 \mathrm{~m}$ depth), a reef specimen, has regular and somewhat larger corallites than my specimens; Coel. 1052 (exact locality unknown) shows much resemblance to Coel. 5853. RMNH No. 358 labelled Goniastrea quoyi H. Milne Edwards \& Haime belongs to the present species and probably comes from a quiet reef site. BMNH No. 1886.12.9.140, collected by the Challenger expedition (Banda, Moluccas), is labelled Goniastrea quoyi $\mathrm{H}$. Milne Edwards \& Haime. In the USNM there are several specimens belonging to the present species in the unregistered collection of $\mathbf{J}$. B. Steere from the southern Philippines, and in the BMNH several from the Great Barrier Reef in the collection of Saville Kent.

The species has been found in the Mergui Archipelago, Indonesian Archipelago, Philippines, Great Barrier Reef, and New Caledonia.
Goniastrea favulus (Dana, 1846). Pl. IX fig. 4.

Astraea (Fissicella) favulus Dana, 1846: 245, pl. XIII fig. 7, holotype USNM No. 66.

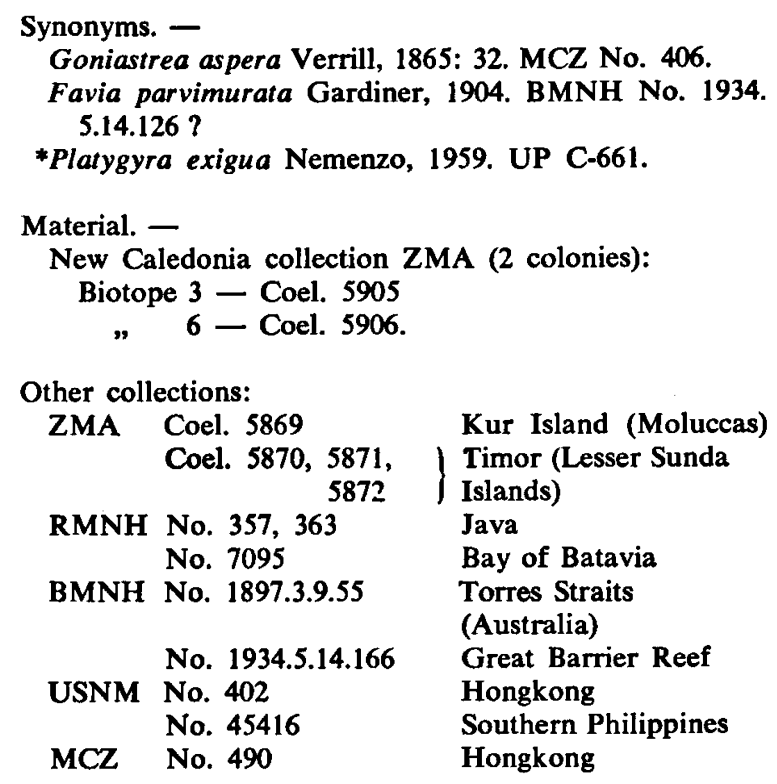

Characters. -

Corallum: The colony is spherical or flat, and cerioid but forming short meanders with a mean diameter of $6 \mathrm{~mm}$. The thecae are thin, at the side of the corallum somewhat thickened. The septa are numerous (about 18 per $10 \mathrm{~mm}$ ), thin, and very finely dentated on the edges; in between the well developed septa rudimentary septa are normally present showing by their alternation a characteristic habit. All primary septa have a well developed paliform rod forming an irregular crown around the columella. The last mentioned structure consists of fine trabeculae.

Polyp: The colour of the living animal is dark brown with a green stomodaeum.

Variability of the characters in the different biotopes. -

Since I have two colonies only, I can not say much about the variability in the species. Coel. 5905 from a shallow site at the inner barrier reef resembles Dana's type specimen closely. The colony is very regular and the short meanders are as long as $20 \mathrm{~mm}$. The specimen from a deeper lagoon site at the fringing reef (Coel. 5906) has larger corallites, only some of which are distomodaeal. The number of septa in this specimen is smaller, and the rudimentary septa are lacking. The more irregularly formed corallum with more dentation 
(aspera ecotype) is not present in my series. Several specimens of this ecotype could be studied in other collections (e.g. 4 colonies from various Siboga stations in ZMA). These will be discussed below.

Discussion. -

The holotype of Goniastrea favulus is a small spherical colony from the Fiji Islands, resembling Coel. 5905. The holotype of Goniastrea aspera Verrill, 1865: 32, is a small flat corallum from Hongkong; one paratype (MCZ No. 490) is a larger colony with a somewhat irregular habit and larger corallites. Another paratype (USNM No. 402) from the same locality as the holotype also shows a more irregular habit, and larger corallites than Dana's Goniastrea favulus. The present synonymy is based on the characteristic alternating septum formation and the many paliform rods. Crossland, 1952: 132, regarded Favia parvimurata Gardiner, 1904, from Hululu, Laccadive Islands, to be synonymous with Favites aspera. After having studied the good photograph given by Gardiner (pl. LXII fig. 25), and a specimen that is probably the type but is not indicated as such, I agree with Crossland. The specimen distinctly shows the aspera form due to the more irregular habit and dentation on thecae and septa. The holotype of Platygyra exigua Nemenzo, 1959: 108, from Lea Island, Sulu, could not be studied but the description and illustration (pl. XIII fig. 2) agree with Goniastrea favulus.

BMNH No. 1934.5.14.166 is the colony discussod by Crossland, 1952: 132, agreeing with the aspera form. BMNH No. 1897.3.9.55 from Torres Straits, as yet unidentified, is a very good example of Goniastrea favulus, showing the regular habit of favulus. Umbgrove, 1940: 30, discusses and illustrates a specimen (RMNH No. 7095) as Favites aspera from the Bay of Batavia. It shows well the aspera form. Faustino, 1927: 141, describes a specimen collected by J. B. Steere in the southern Philippines. This colony is probably the USNM. No. 45416 specimen, that looks like a transitional form between favulus and aspera. In the ZMA there are four spherical reef colonies from different Siboga stations belonging to the presently discussed species: Coel. 5870 \& 5871, Siboga station 282 (Nusa Besi, Timor); Coel. 5869, Siboga station 250 (Kilsuin, Kur Island) and Coel. 5872, Siboga station 296 (Noimini, Timor). They all show the aspera form with the somewhat irregular, dentated habit.
It is interesting that under the present species synonyms classified with four different genera are united (Fissicella Dana, 1846, being essentially synonymous with Favites). This is a good example of how artificial the limits of the genera appear to be. I shall refer to this problem again in the general discussion. As to the present generic delimitation it can be said that the species gives the impression of a Favites (especially Favites melicerum), but primarily because there is a tendency to meander, and also because the theca walls are generally thin and the paliform structure is well developed, I think the species can better be included in Goniastrea, as already has been proposed by Faustino, 1927, and Yabe \& Sugiyama, 1936.

Localities of which the species is known are: Laccadives, Indonesian Archipelago, Hongkong, Philippines, Great Barrier Reef, Torres Straits, New Caledonia, Fiji Islands.

Goniastrea pectinata (Ehrenberg, 1834). PI. IX figs. $1,2,3$.

Astraea pectinata Ehrenberg, 1834: 96, holotype ZMB No. 726.

Synonyms. -

Astraea favistella Dana, 1846. USNM No. 73.

Astraea sinuosa Dana, 1846. USNM No. 71.

Astraea cerium Dana, 1846. USNM No. 64.

Goniastrea planulata H. Milne Edwards \& Haime, 1850. MNHN.

Goniastrea quoyi H. Milne Edwards \& Haime, 1850. MNHN.

Goniastrea grayi H. Milne Edwards \& Haime, 1850 MNHN.

Goniastrea multilobata Quelch, 1886. BMNH No. 86. 12.9.132.

Goniastrea coronalis Quelch, 1886. BMNH No. 1892. 10.16.12. BMNH No. 1886.12.9.142.

Material. -

New Caledonia collection ZMA (23 colonies):

Biotope 1 - Coel. 5882 - 5883 - 5884 - 5885

$$
\begin{array}{ll}
\Rightarrow \quad 2-\text { Coel. } 5887-5886-5888-5889 \\
\Rightarrow \quad 4-\text { Coel. } 5891 \\
\Rightarrow \quad 5-\text { Coel. } 5892-5893-5894-5895 \\
\Rightarrow \quad 6-\text { Coel. } 5896-5897-5902-5903 \\
\quad 7 \quad 7-\text { Coel. } 5898-5899-5900-5901 .
\end{array}
$$

Other collections:

$\begin{array}{lll}\text { ZMA } & \begin{array}{l}\text { Coel. } 1054 \\ \text { Coel. } 5856\end{array} & \begin{array}{l}\text { Singapore } \\ \text { Roti Island (Lesser } \\ \text { Sunda Islands) }\end{array} \\ \text { Timor (Lesser Sunda } & \text { Islands) } \\ \text { Coel. } 5857 & \text { Red Sea } \\ \text { TMNH } & \text { No. } 362 \\ \text { No. } 1093,1099,1103 & \text { Togian Reef (Celebes) }\end{array}$


Characters. -

Corallum: The colony is spherical or encrusting, sometimes cerioid, but mostly meandroid. The average diameter of the valley is $6 \mathrm{~mm}$, ranging from 4 to $8 \mathrm{~mm}$. The collines are usually thin, but may be thickened. The septa, about 16 per $10 \mathrm{~mm}$, are rather thin and fall abruptly into the calyx. The edges are finely and regularly dentated. Around the columella a crown of well developed paliform rods is present. The columella consists of a few twisted trabeculae. The species is very variable, and this will be discussed below.

Polyp: The living animal is brownish-grey with a greenish-grey stomodaeum.

Variability of the characters in the different biotopes. -

For the general discussion of the variation I refer to Favia favus. Again a decrease of skeleton deposit in relation to greater depth is found. Values for the number of septa are given in fig. 12, showing a decrease in the number of septa in relation to depth, but a different relation for outer reef specimens is not very apparent. The number of corallites per square unit cannot be counted in a meandroid corallum and the number of corallite centers per meander does not tell us much about the skeleton deposit. But fig. 13 shows that the meanders become somewhat shorter in deeper water. The same observation is made for $G$. australensis and Platygyra daedalea. The colonies from biotope 1 have a more flattened habitat (planulata type) and show a striking resemblance to the specimens from biotope 7. The colonies from shallower sites (pectinata form) have thinner thecae and usually have narrower meanders. Some specimens from biotope 6 (e.g. Coel. 5897, 5903) have narrow meanders to such a degree that the paliform lobes are hardly developed.

\section{Discussion. -}

Ehrenberg's holotype is a spherical corallum from an unknown locality on the sides of which the skeleton structure is hardly visible, because of the blistered surface. On the top, however, it shows the characters plainly. The meanders are short, making it probable that the type comes from a deeper reef site. In the collection of Umbgrove, 1939, from Togian Bay (Celebes) both growth forms are present. RMNH No. 1103, labelled Goniastrea planulata, is a Goniastrea pectinata with the smooth habit reminiscent of Red
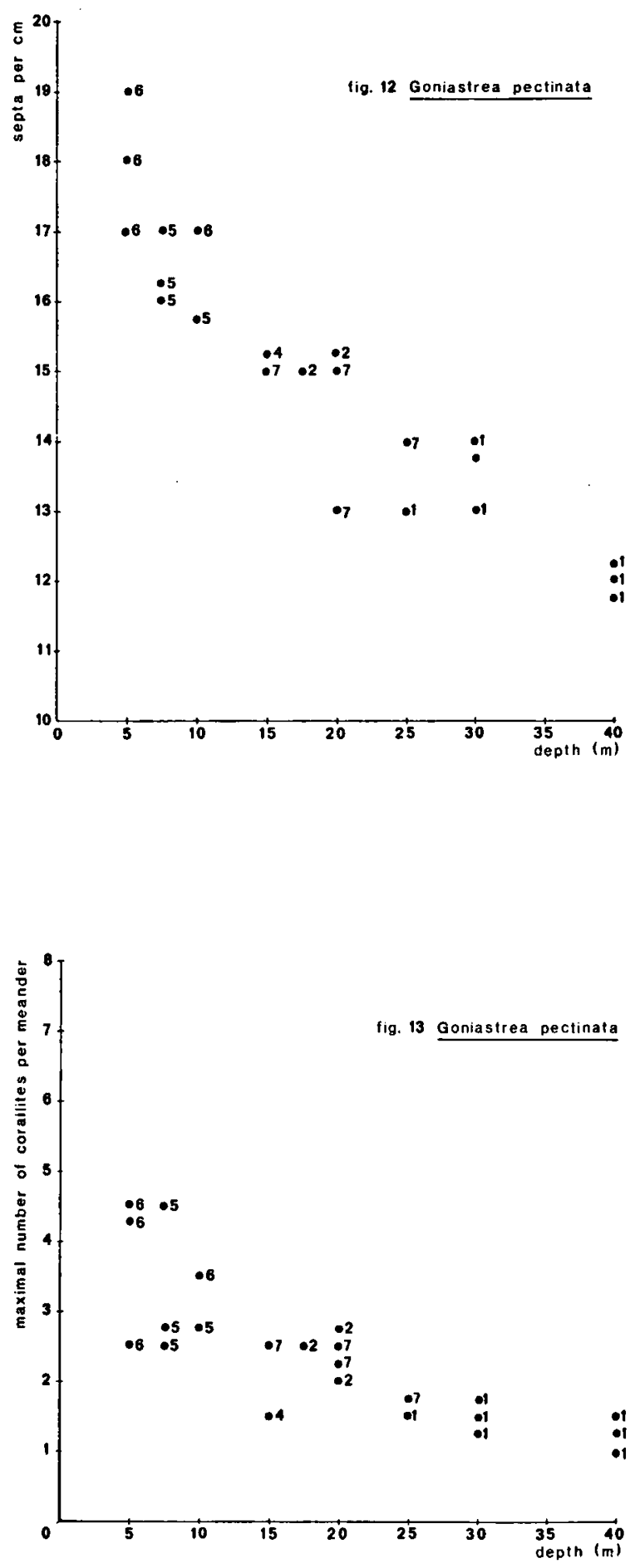

Figs. 12 \& 13. Goniastrea pectinata. Relations between number of septa per $\mathrm{cm}$ and depth of collecting, and between maximal number of corallites per meander and depth of collecting.

Numbers indicate the biotopes. 
Sea specimens. The holotypes of Dana's species Astrae favistella (1846: 241) and Astraea sinuosa (1846: 243), both from the Fiji Islands, are illustrated by Vaughan, 1918, on pl. 42 figs. $4-4 \mathrm{a}$ and pl. 43 fig. 2 , respectively. They belong to the present species, both probably from a shallow reef habitat. Another species of Dana is Astraea cerium, 1846: 245, based on a rather worn corallum from Wake Island; it represents another growth form of Goniastrea pectinata. Goniastrea quoyi H. Milne Edwards \& Haime, 1850: 162, from Tongatabou and Goniastrea grayi $\mathrm{H}$. Milne Edwards \& Haime, 1850: 163, from "Australia", both belong to the present species and appear to come from sheltered reef sites. The latter has a more regular structure. Goniastrea planulata $\mathbf{H}$. Milne Edwards \& Haime, 1850: 162, comes from an unknown locality. Matthai, 1914: 122, already noted the resemblance with Goniastrea pectinata but thought it necessary to examine the polyps first. The specimen resembles my deeper water forms (e.g. Coel. 5885). The more flattened corallum habit with shallower calices and thicker thecae is probably induced by the environment, in the same way as seen in other Faviinae.

In my opinion planulata is a quiet water ecotype of Goniastrea pectinata. The holotype of Goniastrea multilobata Quelch, 1889: 99, from Ambon, is a hillocky colony of a rough dentated habit showing clearly the short meanders. Apparently it comes from an exposed fringing reef habitat. Goniastrea coronalis Quelch, 1886: 101, from Banda, has a more regular structure than the preceding.

This species is adaptive and widespread, and has many synonyms. Most of them were already recognized as such in the literature, because they are clearly growth forms. However, the extreme of the series, Goniastrea planulata, is usually regarded as a separate species. The large series of the two forms pectinata and planulata of the collection Gardiner-Matthai in the BMNH shows the range of the variation clearly and has been studied by Crossland. He considers the two species the extremes of one series. Although he could not arrange the series in relation to the differences in environment for lack of data, I agree with Crossland. In my series planulata proves to be an ecotype from deep or quiet water. Coel. 5856 from Siboga station 301 (Roti Island, dredge, 27 to 45 $\mathrm{m})$ is a planulata ecotype, this substantiating the latter conception. Coel. 1054 has a remarkable growth form with the hillocky structure of Gonias- trea multilobata Quelch. This hillocky habit was met with in some species of Favites too, and the phenomenon is not of specific importance but simply the result of environmental factors.

This widespread species has been found in the Red Sea, the Indian Qcean, and in several localities in the western Pacific.

Goniastrea australensis ( $H$. Milne Edwards \& Haime, 1857). Pl. X figs. 1, 2, 3.

Prionastrea australensis H. Milne Edwards \& Haime, 1857: 520; holotype MNHN.

Synonyms. -

Goniastrea benhami Vaughan, 1917. USNM No. 52722.

*Goniastrea equisepta Nemenzo, 1959. UP C-293.

Material. -

New Caledonia collection ZMA (26 colonies):

Biotope 2 - Coel. 5907

" 3 - Coel. 5908

" 4 - Coel. 5909 - 5910 - 5911-5912 -

$5913-5914-5915-5916$

" 6 - Coel. 5917 - 5918 - 5919-5920 $5921-5922$

, 7 - Coel. 5923 - 5924 - 5925 - 5926 5927 - $5928-5929-5930-$ $5931-5932$.

Other collections:

BMNH No. 1892.12.1.43 Great Barrier Reef No. 1892.12 .57 .4

Great Barrier Reef

Characters. -

Corallum: The colony is cerioiod, but usually forms long meanders varying in length. The average diameter of the valleys is $10 \mathrm{~mm}$, but occasionally up to $15 \mathrm{~mm}$. The theca is usually thin but can be thickened, giving a somewhat plocoid habit. The septa are thin, regular and not exsert. Their number is about 18 per $\mathrm{cm}$. Their edges are finely dentated. In the bottom of the calyx well developed paliform lobes are present in front of all septa giving the valleys a characteristic appearance. The columella is small, consisting of a few twisted trabeculae.

Polyp: The colour of the living animal is yellowish-brown with a bluish-green stomodaeum.

Variability of the characters in the different biotopes. -

The species is well represented on the reefs of New Caledonia. In the series of 26 specimens from the different biotopes, all except one show the typical variation pattern. Specimens from lagoon 

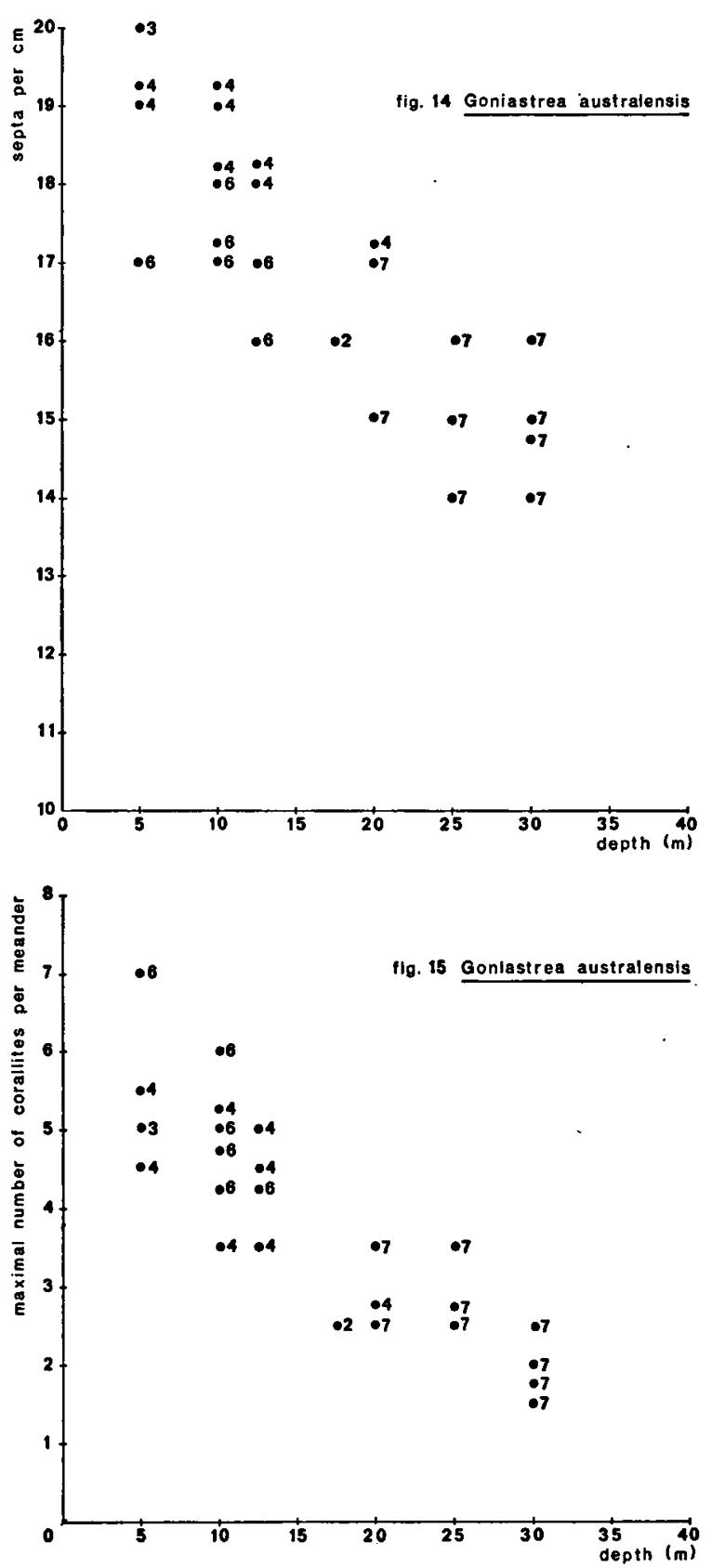

Figs. 14 \& 15. Goniastrea australensis. Relations between number of septa per $\mathrm{cm}$ and depth of collecting and between maximal number of corallites per meander and depth of collecting.

Numbers indicate the biotopes.

and bay biotopes are well represented; those from deeper waters have wide, thick thecae, shallow calices and thorter meanders. The specimens from the shallower lagoon, although growing on a sandy bottom, show resemblance to the specimens from biotope 6 in having much higher thecae, deeper calices and longer meanders. Fig. 14 shows the decrease of skeleton deposit, viz., the decrease in the number of septa per $\mathrm{cm}$ in relation to water depth. Fig. 15 shows that the formation of longer meanders depends on certain environmental factors that vary with depth. The same has been shown for Goniastrea pectinata, which also has a tendency to form meanders. I shall refer to this in the chapter on the general ecology.

\section{Discussion. -}

The holotype is a spherical corallum from Australia. The thecae of the corallites are thin, the valleys may have a length up to 20 to $25 \mathrm{~mm}$, and an average width of $10 \mathrm{~mm}$. The septa and palial lobes are very thin and rather regular. The calyx is deep (about $8 \mathrm{~mm}$ ) and the columella is not distinct. The specimen corresponds with Coel. 5908 and possibly comes from a shallow reef site. The holotype and paratype of Goniastrea benhami Vaughan, 1917: 277, from Meyer Island (Kermadec Islands) are well described and illustrated by the author. They show much resemblance to the specimen of H. Milne Edwards \& Haime, which Vaughan probably overlooked in the literature. Vaughan's holotype from a depth of about $1 \mathrm{~m}$ has a more regular habit, and shows the characteristic palial structure better than the paratype from a depth of about $7 \mathrm{~m}$. The latter has a hillocky surface and somewhat thicker thecae and septa. Of the holotype of Goniastrea equisepta Nemenzo, 1959: 101, from the Philippines (Hundred Islands, Pangasinan), the short description and rather good photograph gave me the impression of dealing with an ecotype (from deeper water) of Goniastrea australensis. It resembles Coel. 5930, a specimen from biotope 7. The corallites are shallow and of a regular habit, the meanders are short, mostly monocentric. All characters given by Nemenzo of his new species correspond well with those of the present one, so I think it is synonymous with $G$. australensis.

There are some records in literature about species that come very close to the presently discussed, but the types of these could not be studied and the descriptions are not sufficient to arrive at a conclusion about their status. Yabe \& Sugiyama, 1936: 37, describe Coeloria? gigantea on the basis of several coralla from various localities around Sikoku and Kyushu. Their description is short but the photographs (pl. XXII figs. 1 and 2) give the impression to concern the present species. 
However, the valleys are very long (the colony coming probably from a shallow site), but the number of septa is about 8 to 10 per $\mathrm{cm}$, as in a colony coming from deep water. This contradiction may indicate that these colonies belong to a separate species closely allied to Goniastrea australensis. Because of the well developed palial structure I suggest to include gigantea at least in Goniastrea.

Another doubtful synonym is Coelogyra levis Nemenzo, 1959: 109. The holotype as described and illustrated by the author comes very close to the species of Yabe \& Sugiyama (a comparison made by the author himself). Some of the specimens in my series e.g. Coel. 5921 come very close to the latter two species, but the number of septa per $\mathrm{cm}$ is generally higher (minimum 14 per $\mathrm{cm}$, but never 8 or 10 per $\mathrm{cm}$ ). In the BMNH there are some specimens collected by Saville Kent at Capricorn Island (Great Barrier Reef) labelled G. benhami Vaughan. They both correspond with my reef specimens. The only other records in literature are those of Vaughan, 1918: 136, who mentions a specimen from Formosa present in the USNM, and Crossland, 1952: 136, who mentions a colony from the Great Barrier Reef.

Localities of the present species are: Kermadec Islands, Great Barrier Reef, New Caledonia, and Formosa, and perhaps the Philippines and Japan.

\section{Platygyra Ehrenberg, 1834.}

Type species. - Maeandra (Platygyra) lamellina Ehrenberg, 1834, by subsequent designation (Brüggemann, 1879: 571).

Diagnosis of the genus (after Wells, 1954). Meandroid, colony formation by linear intramural polystomodaeal budding with lateral branching and terminal forking. Collines narrow, septothecal. Larger septa commonly with small internal paliform lobes. Columella continuous, trabecular.

The following species are discussed:

- Platygyra lamellina (Ehrenberg, 1834).

Rare. Corallum meandroid, valleys long, average diameter $6 \mathrm{~mm}$. Walls thin. Septa regular, well dentated, average number 14 per $\mathrm{cm}$. Last part of septa sometimes fusing, paliform structures present. Columella continuous, trabecular. Polyp brown with a green stomodaeum.
- Platygyra daedalea (Ellis \& Solander, 1786).

Common. Corallum meandroid, sometimes monocentric but usually a few cm long; average diameter $6 \mathrm{~mm}$. Walls thin, often perforated, variable in height; regular, exsert septa with well developed teeth and an average number of about 13 per cm; paliform lobes hardly present. Columella continuous and of a loosely trabecular texture. Polyp brown with a green stomodaeum.

- Platygyra sinensis (H. Milne Edwards \& Haime, 1849).

Rare. Corallum spherical or flat; meandroid with short valleys. Average diameter of the valley 3 to $4 \mathrm{~mm}$. Septa not exsert, regular and finely dentated; average number 10 per $\mathrm{cm}$. Columella consisting of small bunches of twisted trabeculae. Polyp yellowish-brown

Platygyra lamellina (Ehrenberg, 1834). Pl. X fig. 4.

* Maeandra (Platygyra) lamellina Ehrenberg, 1834: 99; holotype ZMB, lost.

Synonyms. -

Coeloria bottai H. Milne Edwards \& Haime, 1849. MNHN.

Coeloria laticollis H. Milne Edwards \& Haime, 1849. MNHN.

Coeloria subdentata H. Milne Edwards \& Haime, 1849. MNHN.

Coeloria forskalana H. Milne Edwards \& Haime, 1851. BMNH No. 28.10.10.52 (syntype).

Coeloria leptoticha Klunzinger, 1879. ZMB No. 2187.

Material. -

New Caledonia collection ZMA (4 colonies):

Biotope 4 - Coel. 4972

" 5 - Coel. $4973(2 \times)$

" 7 - Coel. 4974.

Other collections:

ZMA Coel. 196

Coel. 1695

Coel. 5933

RMNH No. 227, 228, 229,230

No. 7098

Indian Ocean (unspecified)

Nosy Bé (Madagascar)

Saleyer (Java Sea)

Java (Indonesia)

Bay of Batavia

(Indonesia)

BMNH. Collection Gardiner-Matthai $\}$ Diverse localities

USNM. One unregistered $\left.\begin{array}{l}\text { specimen, collected } \\ \text { by Gravier }\end{array}\right\}$ Djibouti Unregistered specimens collected $\}$ Southern Philippines by Steere

PAS. One unregistered specimen 
Characters. -

Corallum: The meandroid colony is spherical or flat. The meanders are of various length but are in general long and winding; their average width is $6 \mathrm{~mm}$. The walls are thin but can be thickened. The septa, hardly exsert and evenly arranged, are regularly dentated; their average number varies from about 12 to about 18 per cm; they fall steeply down into the bottom of the valley. The parts of the septa in the bottom of the calyx sometimes fuse with each other, paliform structures are often present. The columella is continuous, trabecular.

Polyp: The colour of the living animal is brown with a green stomodaeum.

Variability of the characters in the different biotopes. -

Since the four specimens of the New Caledonia series all come from shallow and sheltered inner reef sites, not much variation is present. The bay specimen Coel. 4974 has a lighter texture and the valleys are shallower, with an average depth of $4 \mathrm{~mm}$. The lagoon specimens have a more irregular habit with deeper valleys with an average depth of $6 \mathrm{~mm}$.

\section{Discussion. -}

The holotype of Ehrenberg (1834: 99) could not be traced, and his diagnosis is too short to obtain a good idea of the specific characters. This plastic species was substantiated by Matthai (1928: 37), who first discussed the status of the name and next gave an extensive description and a good illustration of it. All the names given by $\mathrm{H}$. Milne Edwards \& Haime, 1849, 1851, for different meandroid Red Sea colonies, were comprised by Klunzinger, 1879: 17 in the name Coeloria arabica, a collective name, which cannot be but a junior synonym. All are growth forms of $P$. lamellina, in which opinion I join Verrill (1901) and Matthai (1928). The holotype of Coeloria leptoticha Klunzinger, 1879: 20, differs from $P$. lamellina mainly in having shallower and shorter valleys. These features are due to environmental influences, viz. a deeper, more sheltered site.

In the literature there are scattered records of this species, as a rule of faunistic nature only and not adding new aspects to the discussion of Matthai.

RMNH No. 7098 from the Bay of Batavia, shows much resemblance to Coel. 4974; both are specimens from a sandy bottom. An unregistered specimen from Djibouti collected by Gravier (USNM), also, shows shallower valleys and broader collines. ZMA Coel. 5933 from Siboga station 213 (Saleyer, coral reef, mud, sand, depth up to $36 \mathrm{~m}$ ) is a heavy, spherical corallum of rather regular structure. Coel. 1695 from Madagascar (Pointe de la Fièvre, Nosy Bé, about $2 \mathrm{~m}$, leg. Stock) has the typical long winding meanders and a regular septal structure.

In general the large variation present in this species concerns mainly the length of the valleys and the height and widths of the collines. In more quiet water the valleys are shorter and the collines low and broad.

Other relations between the morphological variation and the environment could not be defined.

The range of the species extends from the East coast of Africa to Polynesia.

Platygyra daedalea (Ellis \& Solander, 1786). Pl. XI figs. 1, 2.

Madrepora daedalea Ellis \& Solander, 1786: 163, pl. 46 fig. 1, holotype $\mathrm{Gl}$.

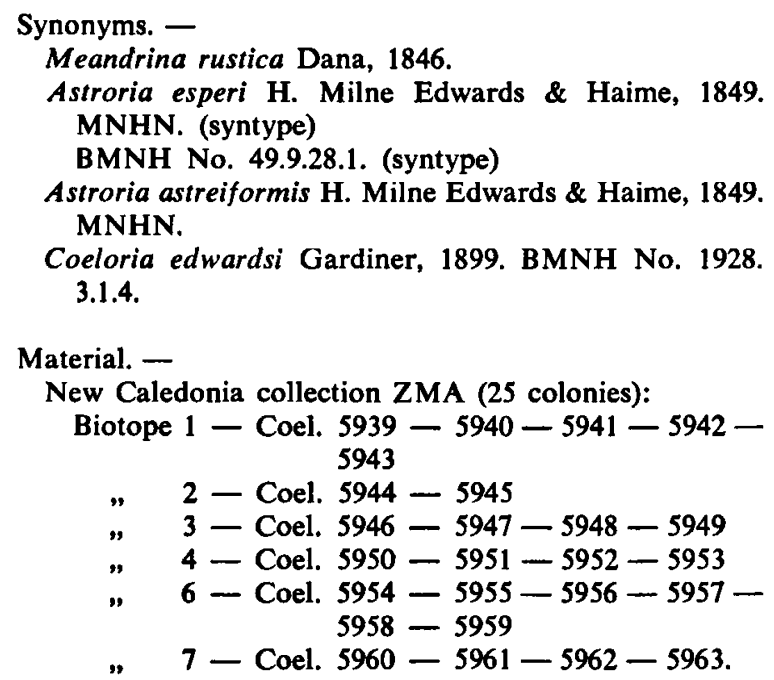

Other collections:

ZMA Coel. 192, 193, 201 Indian Sea

(unspecified)

Coel. 195, $198 \quad$ Singapore

Coel. 1703, 1709, 1710 Nosy Komba

(Madagascar)

Coel. 1721

Nosy Bé

Coel. 1871, 5603

Coel. 5964

(Madagascar)

Mauritius

Dangar Besar

(Sumbawa)

Coel. 5965

Saleyer (Java Sea) 
RMNH No. 1107, 1108, 1109, $\left.\begin{array}{l}1110,1111,1112, \\ 1113,114\end{array}\right\}$ No. 7097

Togian Reef (Celebes)

Bay of Batavia

BMNH Collection Gardiner-Matthai

No. 1868.4.2.1

No. 1928.3.1.2

Gulf of Persia

Salomon Island

(Chagos)

Characters. -

Corallum: The meandroid colony can be either spherical or flat. The valleys are sometimes monocentric, but in general are several $\mathrm{cm}$ long and their average diameter is $6 \mathrm{~mm}$. The walls are thin, often perforated and variable in height. The irregular, exsert septa with well developed teeth vary in number from about 10 to about 15 per $\mathrm{cm}$. They fall abruptly down into the calyx, and paliform lobes are hardly present. The columella is continuous and of a loosely trabecular texture. Polyp: the colour of the living animal is brown with a green stomodaeum.

Variability of the characters in the different biotopes.

This common Pacific species is well represented in the collection from New Caledonia. The general relation between skeleton deposit and depth as given in fig. 16, is the same as seen in other Faviinae. The flat, almost two-dimensional growth in deeper water (biotopes 1, 4, and 7) and the spherical three-dimensional growth forms under more favourable circumstances for living also correspond to what is usually found in other Faviinae. As to the length of the valleys, fig. 17 shows that deep water forms have shorter valleys than those of shallower water (compare fig. 13 of Goniastrea pectinata and fig. 15 of Goniastrea australensis).

A notable feature is that in the large and spherical colonies rather long meanders occur on the more exposed side of the colony, while shorter or even monocentric ones are present on the sheltered sides of the corallum. The species is extremely variable in diameter of the collines and dentation of the septa.

Discussion. -

The holotype of this species from "Oceano Indiae orientalis" is a rounded, rather smooth colony with few septa (about 11 per $\mathrm{cm}$ ) and thin, often perforated walls. The holotype of Meandrina rustica Dana, 1846: 258, from Wake Island is a rather worn specimen with long meanders.
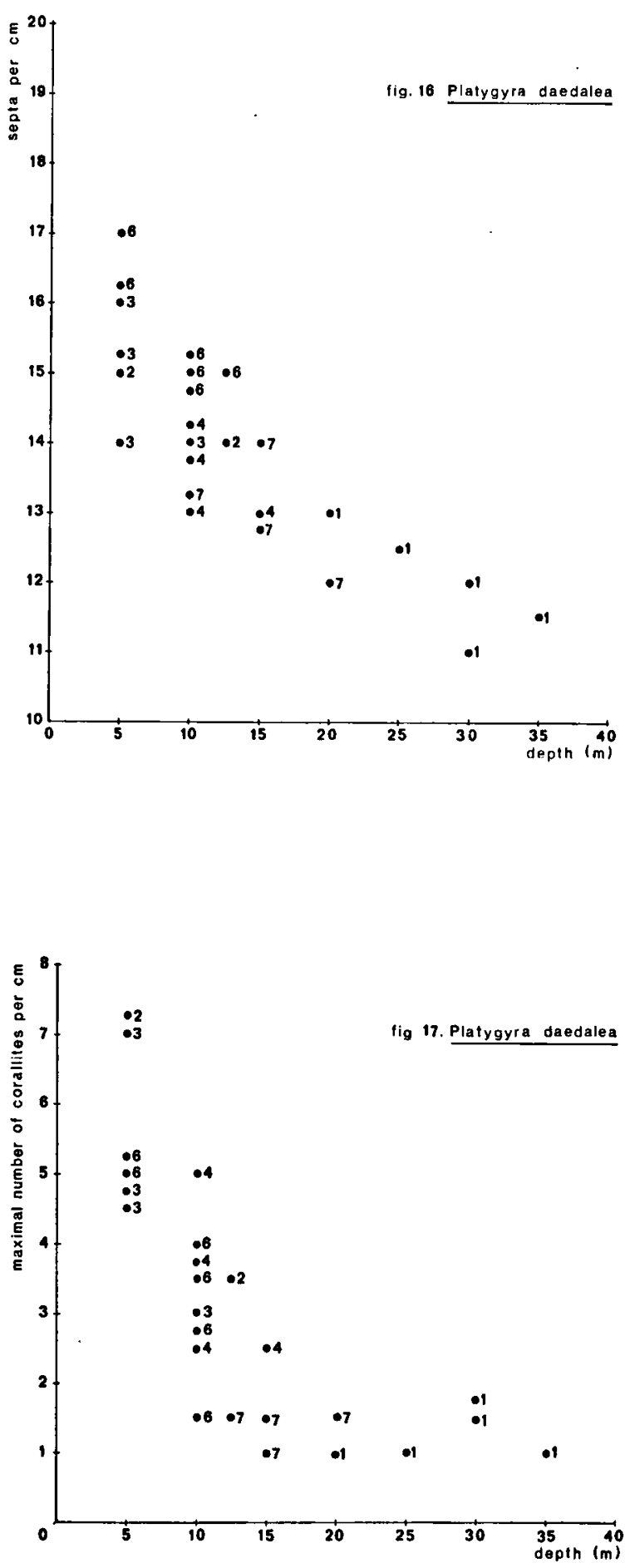

Figs. 16 \& 17. Platygyra daedalea. Relations between number of septa per $\mathrm{cm}$ and depth of collecting, and between maximal number of corallites per meander and depth of collecting.

Numbers indicate the biotopes. 
Vaughan, 1918: 119, regards it as synonymous with $P$. lamellina, which might well be the case. Since the specimen is not good enough for specific identification further discussion will not be very fertile. One of the types (MNHN) of Astroria esperi H. Milne Edwards \& Haime, 1849: 298, from the Red Sea is a flattened colony with short meanders and rather broad collines: a growth form of Platygyra duedalea of a more sheltered site. All authors but Klunzinger, 1879: 19, and Hoffmeister, 1925: 29, regarded the species already as such. The holotype of Astroria astreiformis $\mathbf{H}$. Milne Edwards \& Haime, 1849: 299, also from the Red Sea, is generally regarded as a separate species. The colony is of a light texture, practically permanently monocentric and with very thin septa. This species can be considered to be an extreme growth form from deep, quiet waters. The holotype of Coeloria edwardsi Gardiner, 1899: 744 , from Rotuma also falls within the range of Platygyra daedalea as well. Matthai, 1928: 24, gave an extensive discussion of this species. Most of the later records of Platygyra daedalea are limited to a short note.

In other collections I have come across many representatives of this species. When detailed environmental data were known, they usually corresponded with my results. Some reef specimens from Singapore, e.g. Coel. 195, have higher (up to 12 $\mathrm{mm}$ ) and thinner thecae, also seen in Coel. 1721 from Madagascar (Pointe de la Fièvre, Nosy Bé, 1 to $2 \mathrm{~m}$ in depth, leg. J. H. Stock).

Just as I noticed in my own collection, the large and spherical colonies have longer meanders on top and astreiformis-like shorter ones on the sides. In some specimens of Umbgrove's collection of the Togian Reef the same feature is found (e.g. RMNH No. $1107,1108,1109,1111,1112,1114)$. It is interesting to quote Umbgrove, 1940: 283, remarking: "I pointed out the occurrence of calices of the astreiformis-type in C. daedalea auctorum. I presume that the two 'species' intergrade".

The species is common in the Indian and Pacific Oceans, extending from the East coast of Africa to the Tuamotu Archipelago.

A closely allied species, Platygyra klunzingeri Matthai, 1928: 47, is not present in the New Caledonia collection, but may be commented upon here since some fine specimens are available: ZMA Coel. 5970 from Siboga station 296 (Noimini, Timor, reef, depth 8 to $36 \mathrm{~m}$ ) and Coel. 5971 (Thousand Islands, Java Sea). They agree in every detail (high and thin thecae, thin and narrow septa, secondary septa undeveloped, and bottom of valley vesicular) with the holotype BMNH No. 28.3.1.14. Another specimen is BMNH No. 1883.3.24.3 (Galle, Ceylon, leg. Ondaatje). As far as I can judge from description and figures of Platygyra ryukyuensis Yabe \& Sugiyama, 1936: 38, pl. XXVIII figs. 3, 4 and 5 , this species is synonymous with Platygyra klunzingeri. Despite their close resemblance, Platygyra klunzingeri and Platygyra daedalea can be separated on the basis of the former's fewer and thinner septa and vesicular columella structure.

Platygyra sinensis (H. Milne Edwards \& Haime, 1849). Pl. XI fig. 3.

Astroria sinensis H. Milne Edwards \& Haime, 1849: 298; holotype MNHN.

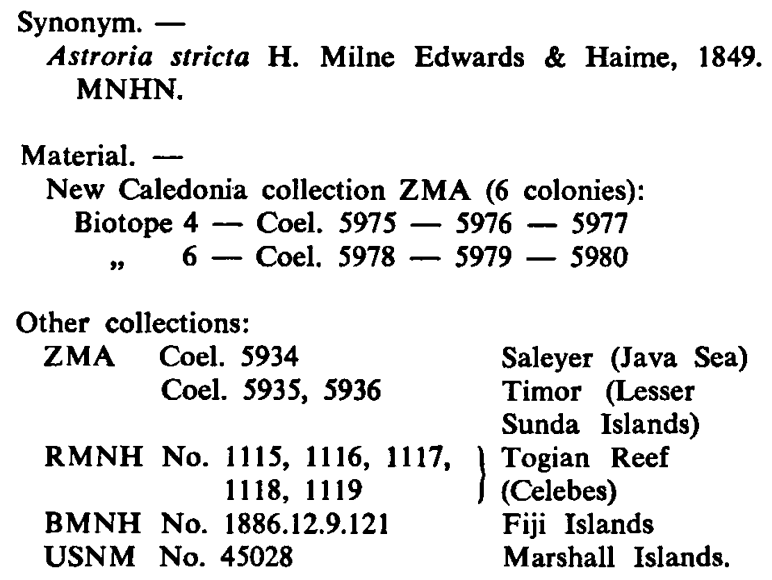

Characters. -

Corallum: The colony is spherical or flat, usually smaller than Platygyra lamellina or Platygyra daedalea. The growth form is usually meandroid with short valleys, but sometimes several $\mathrm{cm}$ long. The average diameter of the valleys is 3 to $4 \mathrm{~mm}$. The septa are not exsert, regular in structure and finely dentated, varying in number from about 8 to about 12 per $\mathrm{cm}$. They fall abruptly down into the calyx; paliform lobes are not present. The columella consists of twisted trabeculae, sometimes arranged in small packs.

Polyp: The colour of the living animal is yellowishbrown.

Variability of the characters in the different biotopes. -

Because all specimens of the New Caledonia series come from a shallow fringing reef facies, 
not much variability was seen in this series. Variations as a result of environmental influences in different microhabitats were as follows. Coel. 5979 is a spherical colony from a depth of about $10 \mathrm{~m}$, the corallites are practically all monocentric, some are distomodaeal. Coel. 5980 has much longer meanders, up to $3 \mathrm{~cm}$, but at the sides they become shorter. This decrease in meandering under the influence of a decrease of light is likewise seen in other meandroid species, in particular Platygyra daedalea.

\section{Discussion. -}

The holotype of this species from "les Mers de la Chine" is a small colony with short valleys, thin thecae and a regular habit, corresponding to the reef specimens of my series. The holotype of Coeloria stricta H. Milne Edwards \& Haime, 1849: 299, from Malacca, resembles closely Coeloria sinensis. The only differences are that most of the corallites are monocentric and that the number of septa per $\mathrm{cm}$ is slightly higher. These characters, however, are not of specific value; therefore, the latter species can be regarded a mere growth form.

In the literature there exists some controversy about the status of Platygyra sinensis. Vaughan, 1918: 120, records the species from Murray Island under the name $P$. stricta. The illustration (pl. 45 figs. 3 and $3 a$ ) is good enough for identification. Matthai, 1928, regards $P$. sinensis synonymous with $P$. daedalea; he is followed by Umbgrove, 1940: 283, who describes the species as "the sinensis-stricta-type of C. rustica". For Wells, 1954: 462, it is again a separate species, with which I agree, having studied his specimens, e.g. USNM No. 45028. Coel. 5935 and 5936 from Siboga station 282 (Nusa Besi, Timor, sand, coral, depth 27 to $54 \mathrm{~m}$ ) are spherical coralla, slightly differing from the New Caledonia specimens by having narrower valleys ( $3 \mathrm{~mm}$ and less). Coel. 5934 from Siboga station 213 (Saleyer, coral reef, depth up to $36 \mathrm{~m}$ ) is very typical for the present, species, but has meanders on top of the colony with a length of 6 to $7 \mathrm{~cm}$; however, at the sides the valleys are shorter. Other typical specimens are mentioned above.

Localities of the present species are: Malacca, China Sea, southern Philippines (Faustino, 1927, pl. 34 figs. 2 and 3, pl. 35 figs. 2 and 3), Indonesian Archipelago, Murray Islands, New Caledonia, Marshall Islands and the Fiji Islands.
Oulophyllia H. Milne Edwards \& Haime, 1848.

Type species by monotypy. - Meandrina crispa Lamarck, 1816.

Diagnosis of the genus (after Wells, 1954). Like Favites, but meandroid; colony formation by intramural polystomodaeal budding. Series short, discontinuous, separated by simple, acute, parathecal collines. Centers linked by trabeculae.

The following species is here discussed:

Oulophyllia crispa (Lamarck, 1816). Pl. XI fig. 4.

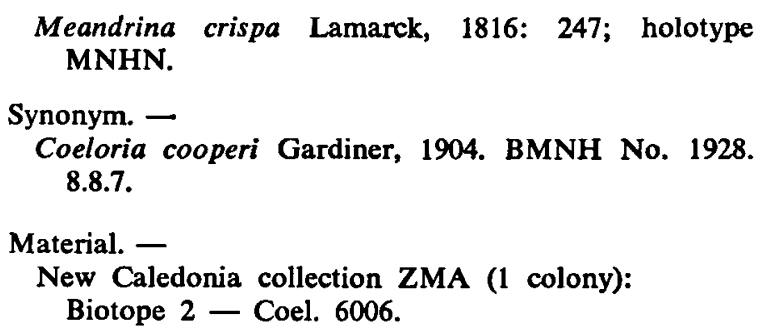

Characters. -

Corallum: The colony is massive and meandroid; the texture is light. The valleys are long, the walls are thin and up to $10 \mathrm{~mm}$ high; the width of the valley is $10 \mathrm{~mm}$ or more. The septa are thin and well dentated, the lower teeth can be rather long. Sometimes the septa are very exsert, giving the colony an aspect like that of Pectinia. The columella consists of loosely twisted septal trabeculae. Polyp: The colour of the living animal is brown.

\section{Discussion. -}

Because only one colony of this genus is present, the data about synonymy and variability cannot be complete. The genus is rather atypical for the Faviinae and therefore no special attention was given to it during the field work. It is discussed here next to Platygyra, since it is most closely allied to that genus.

There are only a few records in literature of the genus Oulophyllia. Quelch, 1886: 88, described two new species, Oulophyllia aspera (holotype BMNH No. 1886.12.9.101) and $O$. cellulosa (holotype BMNH No. 1886.12.9.102) from Banda, both looking different from the New Caledonia specimen. Gardiner, 1904: 762, includes two new species of Oulophyllia in the genus Coeloria (= Platygyra):

- C. cooperi from Hululu (Maldives), according to Matthai, 1928, synonymous with Outophyllia crispa; 
- C. magna (type not traced) from Addu (Maldives), which according to Matthai, 1928, is probably synonymous with Oulophyllia aspera Quelch.

Matthai, 1928: 256, recognizes only two species: Oulophyllia crispa (Lamarck) and $O$. aspera (Quelch). He criticizes Gardiner for lumping Oulophyllia and Coeloria. Matthai's main arguments are that in the first the valleys are wider and deeper, and that the septa are comparatively narrower and thinner. Yabe \& Sugiyama, 1936: 42, mention $O$. crispa from Palau. Their figures (pl. XXV fig. 6 and pl. XXXIV fig. 4) do show a good representation of the present species. Crossland, 1952: 146, differs in his opinion about the generic status from Matthai, 1928. He sympathizes with Gardiner, "the present tendency to make numbers of genera with one to three species each being very inconvenient". Crossland gives one more record of $O$. crispa of the Great Barrier Reef. Wells, 1956: 461, mentions the species from the Marshall Islands.

Only a more detailed study based on a larger series can elucidate the status of Oulophyllia in the Faviinae, the number of species and their synonymy.

\section{Leptoria H. Milne Edwards \& Haime, 1848.}

Type species by monotypy. - Madrepora phrygia Ellis \& Solander, 1786.

Diagnosis of the genus (after Wells, 1954). Meandroid; colony formation by intramural polystomodaeal budding. Collines simple, thin, septathecal. Columella thin, lamellar, continuous or not.

The following species is here discussed:

Leptoria phrygia (Ellis \& Solander, 1786). PI. XII figs. $1,2$.

Madrepora phrygia Ellis \& Solander, 1786: 162, pl. 48 fig. 2; holotype Gl.

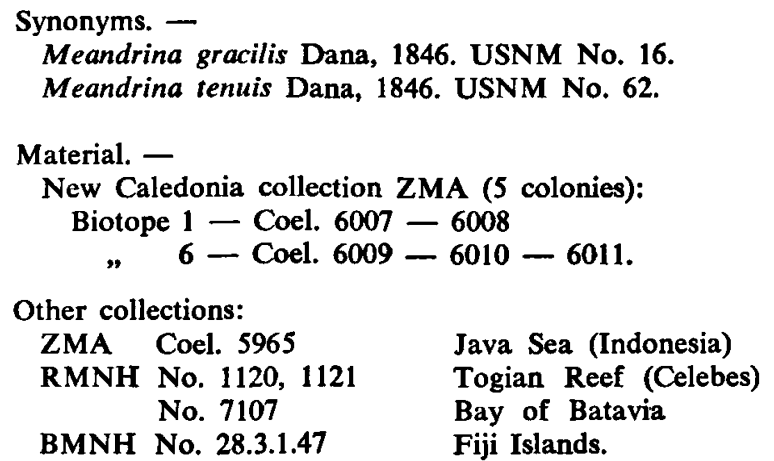

Characters. -

Corallum: The meandroid colony is spherical or flat. The valleys are long with an average diameter of $4 \mathrm{~mm}$. The walls are usually thin but sometimes thickened; the septa are regular, evenly and finely dentated. Their number per $\mathrm{cm}$ varies from about 14 to about 20. At the upper part of the calyx the septa are horizontal, before falling abruptly down to the columella. Paliform lobes are absent. The columella is interrupted and lamellar, a typical character of Leptoria.

Polyp: The colour of the living animal is brown, the stomodaeum sometimes being green.

Variability of the characters in the different biotopes. -

The five specimens present in the New Caledonia series do not show much variation. They all have the characteristic regular habit of the species and differ only from each other in the thickness of the walls and in the number of septa per $\mathrm{cm}$. The two outer reef specimens (gracilis form) from a depth of about $25 \mathrm{~m}$ have broader collines and fewer septa (about 16 per $\mathrm{cm}$ ) than the fringing reef specimens from a shallow habitat (about 20 per $\mathrm{cm}$ ).

\section{Discussion. -}

The holotype of $M$. phrygia (Ellis \& Solander, 1786) from the Pacific (no exact locality known) is an ellipsoid corallum; a good illustration is given (pl. 48 fig. 2). The holotype of Meandrina gracilis Dana, 1846: 261, from the Fiji Islands, is an encrusting corallum with walls up to $3 \mathrm{~mm}$ in width and with 15 to 20 septa per $\mathrm{cm}$. The holotype of Meandrina tenuis Dana, 1846: 262, also from the Fiji Islands, is a spherical colony, resembling closely the specimen of Ellis \& Solander.

In literature there exist many controversial opinions about the three named taxa in this well characterized genus, although tenuis seems to be generally accepted as a synonym.

In 1918 Vaughan distinguished the three species as distinct ones, although he was aware of the close resemblance between them. He described Leptoria phrygia from Cocos Keeling and Leptoria gracilis from Murray Island. Hoffmeister, 1925: 27, considered phrygia and gracilis growth forms of one species, basing his opinion on specimens from Samoa. The extensive discussion of Matthai, 1928, about phrygia = tenuis (: 12) and gracilis (: 22) is based on many museum specimens. The concept of Leptoria phrygia of Yabe \& Sugiyama, 1936, 
is a wrong one: their figure (pl. XXVIII fig. 2) shows Platygyra daedalea.

Umbgrove's material from the Indonesian Archipelago contains the two growth forms phrygia and gracilis. Umbgrove, 1940: 284, concluded that "the presumed differences of $P$. phrygia (and tenuis) and $P$. gracilis are worth of an intensive study of large suite of coral in loco" and uses only the name $P$. phrygia.

Crossland, 1952: 150, too, is of the opinion that the distinction between the species is rather vague. Although my series is not large enough either, I consider it justified to regard gracilis a growth form from deeper or more quiet water, since thicker thecae, shallower valleys and fewer septa are modifications of variable characters, adapted in the same way as in other Faviinae (decrease of skeleton deposit in relation to greater depth).

Localities of the present species are: Red Sea (vide Crossland, 1952: 150), Indonesian Archipelago, southern Philippines (Faustino, 1927, pl. 33 fig. 3), Japan (Yabe \& Sugiyama, 1936, pl. XXVIII fig. 2), New Caledonia, Great Barrier Reef (Crossland, 1952: 150), Cocos Keeling, Murray Island, and the Fiji Islands.

Hydnophora Fischer de Waldheim, 1807.

Type species by monotypy. - Hydnophora demidovii Fischer de Waldheim, 1807 (= Madrepora exesa Pallas, 1766).

Diagnosis of the genus (after Wells, 1956). -

Hydnophoroid; colony formation by circum mural polystomodaeal budding. Collines discontinuous, short, conical. Columella trabecular to lamellar, discontinuous.

The following species are here discussed:

- Hydnophora exesa (Pallas, 1766).

Rare. Corallum encrusting, spherical to dendroid; valleys continuous, width about $4 \mathrm{~mm}$; monticules usually elongated, about $5 \mathrm{~mm}$ high; about 10 septa per conical monticule, septa broadening near columella, edges finely dentated; columella, continuously surrounding the monticules but often not well developed.

Polyp: brown, with bluish-green stomodaeum.

- Hydnophora microconos (Lamarck, 1816).

Rare. Corallum spherical; valleys narrow (about $3 \mathrm{~mm}$ ), continuous; monticules about $2 \mathrm{~mm}$ thick and short, about 10 septa per monticule; edges of the septa hardly dentated; columella lamellar.

Polyp: yellowish-brown.
- Hydnophora rigida (Dana, 1846).

Rare. Corallum branching; valleys narrow (width about $4 \mathrm{~mm}$ ), monticules conical (up to $4 \mathrm{~mm}$ height), often forming ridges; about 12 septa per monticule, edges of the septa dentated; columella forming centers.

Polyp: light brown.

Hydnophora exesa (Pallas, 1766). Pl. XIII figs. $1,2,3,4$.

*Madrepora exesa Pallas, 1766: 290; holotype ?

Synonyms. -

*Madrepora contignatio Forskål, 1775. UZMC Lost.

Hydnophora demidovii Fischer de Waldheim, 1807. MNHN.

Monticularia folium Lamarck, 1816. MNHN.

Monticularia lobata Lamarck, 1816. MNHN.

Monticularia polygonata Lamarck, 1816. MNHN.

*Monticularia meandrina Lamarck, 1816. MNHN.

Hydnophora gyrosa H. Milne Edwards \& Haime, 1849. MNHN.

Hydnophora ehrenbergi H. Milne Edwards \& Haime, 1849. MNHN.

*Hydnophora tenella Quelch, 1886. BMNH ?

Hydnophora grandis Gardiner, 1904. BMNH No. 28.4. 18.227.

Hydnophora maldivensis Gardiner, 1904. BMNH No. 28.10.10.56.

Hydnophora tenella var. applanata Umbgrove, 1940. RMNH No. 1130.

Material. -

New Caledonia collection ZMA (6 colonies):

Biotope 1 - Coel. 5993

" 2 - Coel. 5994

" 4 - Coel. 5995

, 5 - Coel. 5996

" 6 - Coel. 5997

" 7 - Coel. 5998.

Other collections:

ZMA Coel. 549, 550

Coel. 551

Coel. 1726

Coel. 5999, 6000

Coel. 6001

Coel. 6002

RMNH No. 390, 392, 393

No. 7100,7105

BMNH No. 78.6.6.25

No. 86.12.9.124

No. 1846.8 .21 .8

No. 1892.12.1.228

Singapore

Red Sea (unspecified)

Nosy Bé (Madagascar)

Riau (Singapore)

Gébé Island (Moluccas)

Binongka (Celebes)

Japan (unspecified)

Bay of Batavia

Singapore

Banda (Moluccas)

Great Barrier Reef

Great Barrier Reef

Characters. -

Corallum: The hydnophoroid colony is massive or encrusting, sometimes forming branches. The meanders are continuous, the width varying between 3 and $6 \mathrm{~mm}$. The monticules are very varia- 
ble in height and structure, usually strongly built and rather high, up to $5 \mathrm{~mm}$; often some monticules fuse together forming ridges. There are about 10 septa per conical monticule, thin and hardly dentated; they broaden near the columella. The latter structure consists of loosely twisted septal teeth, surrounding the monticules.

Polyp: The colour of the living animal is brown with a large bluish-green stomodaeum.

Variability of the characters in the different biotopes. -

Although the New Caledonia series of the present species is not large enough for graphical treatment, the six specimens present show the interpopulational variability clearly. Coel. 5996 and 5997 from shallow inner ref sites are massive coralla with a tendency to form branches and high conical monticules (gyrosa-type). The heavier and flatter built corallum Coel. 5994 of the exposed outer reef, has more closely set and smaller, but pointed monticules. Coel. 5993 from a sheltered cave outside the barrier reef at a depth of $30 \mathrm{~m}$, has flatter monticules and wider valleys (tenellatype). The lagoon ecotype Coel. 5995 living on a sandy bottom has a light textured corallum with large flat hydnae, resembling in all details $H y d n o-$ phora grandis of Gardiner, 1904. The bay form Coel. 5998 is a thin foliaceous colony with extremely flat and broad monticules, often forming ridges, resembling Hydnophora maldivensis Gardiner, 1904. This series shows very well the extreme growth forms to which an adaptive species can extend. Lighter coralla with flatter monticules, wider apart, are expected in a biotope where conditions are lesse favourable. The observations corroborate the general relation between skeleton deposit and habitat as found in other Faviinae.

\section{Discussion. -}

The holotype of Hydnophora exesa is probably lost. Matthai, 1928: 141, remarks that quite recognizable figures of the species were given for the first time by Esper (pl. XXXI figs. 1-3). The holotype of Hydnophora contignatio Forskăl. 1775: 134, is lost (Crossland, 1941: 39), but contignatio is generally accepted as a synonym of exesa. The type of Hydnophora gyrosa $\mathbf{H}$. Milne Edwards \& Haime, 1849: 303, from the Red Sea has elongated and pointed monticules, resembling my specimens from inner reef sites. The four species of Làmarck: Monticularia folium, M. lobata, $M$. polygonata, and $M$. meandrina, all from
"l'Océan des Grandes Indes", were regarded already synonymous with Hydnophora exesa by Matthai, 1928: 140. As far as I have seen the holotypes I agree with Matthai. The holotype of Hydnophora ehrenbergi $\mathrm{H}$. Milne Edwards \& Haine, 1849: 304, from the Red Sea, comes very close to the gyrosa type. The holotype of Hydnophora tenella Quelch, 1886: 96, from Zamboanga (Mindanao) could not be traced, but the author's drawing (pl. $\mathrm{V}$ fig. 8) and the description given by Matthai, 1928: 153, convince me that a deeper water ecotype of the present species is concerned, corresponding to the specimens of New Caledonia biotope 1. The holotype of Umbgrove's Hydnophora tenella var. applanata, 1940: 284 , from the Togian Reef shows the same structure, it is a light encrusting corallum with flat and broad monticules, but in a more extreme way Umbgrove (: 285$)$ even remarks " ..... the structure of typical Hydnophora tenella occurs in the marginal parts of the Togian specimens". The holotype of Hydnophora maldivensis Gardiner, 1904: 765, from the Maldives is a growth form of the tenella type. The holotype of Hydnophora grandis Gardiner, 1904: 764, from the Maldives corresponds to Coel. 5995. Later authors e.g. Matthai, 1928, Yabe \& Sugiyama, 1936, and Umbgrove, 1939, regard grandis as a separate species. Although at first it differs markedly from a typical $H$. exesa in having a much lighter corallum, broader monticules and wider valleys, I consider it an ecotype of the present species, because this lagoon form shows the structure that is expected in view of the variation seen in other species of the Faviinae. RMNH No. 392 labelled Hydnophora grandis is a large colony showing the grandis type at the basis and the tenella type on the more hillocky part of the corallum.

Because specimens belonging to the genus $\mathrm{Hyd}$ nophora are relatively rare, the variation in $\mathrm{Hyd}$ nophora exesa is not well known. Therefore so many names based on one or just a few coralla are known in literature. The most important records have already been mentioned above. Faustino, 1927: 149, based his conclusion that tenella is a growth form of exesa on the series from the southern Philippines collected by Steere. The specimens from other collections fit the pattern of variation described above. Most of them show the common reef form (gyrosa type), but at the basis of large colonies we often find the tenella type. Coel. 6001 from Siboga station 149 (Gébé Island, reef, depth about $30 \mathrm{~m}$ ) is a large branching 
colony with the tenella type on top and the maldivensis type of monticules at the basis.

Localities of the species are: Madagascar, Maldives, Red Sea, Singapore, Indonesian Archipelago, southern Philippines, Murray Island, Great Barrier Reef, New Caledonia, and the Ellice Islands.

Hydnophora microconos (Lamarck, 1816). Pl. XII fig. 3.

*Monticularia microconos Lamarck, 1816: 251; holotype MNHN, lost.

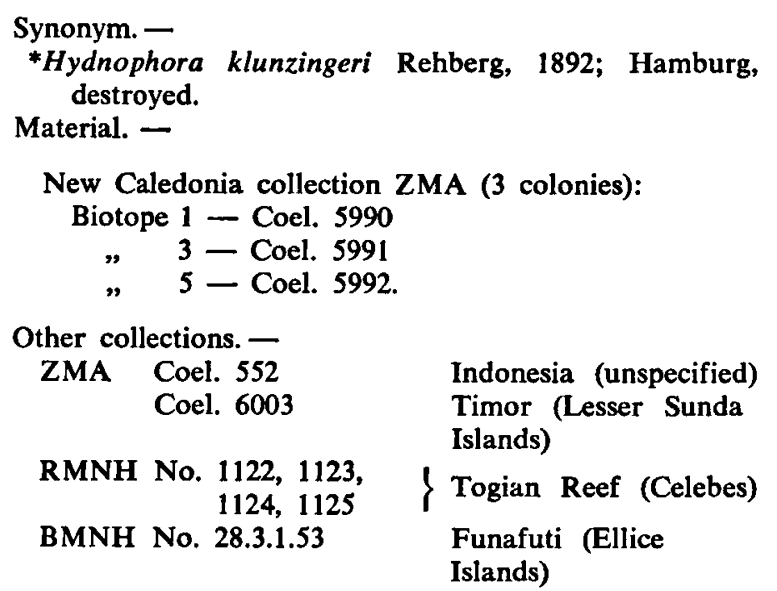

Characters. -

Corallum: The hydnophoroid colony is usually spherical. The valleys are continuous and narrow, average width $3 \mathrm{~mm}$. The monticules are smaller than those of Hydnophora exesa, and about 2 $\mathrm{mm}$ thick. The septa, in average 10 per monticule, are usually horizontal at the top of the monticule (giving it a star-shaped aspect), then fall abruptly down towards the columella. The edges of the septa are hardly dentated. The columella is lamellar, encircling the monticule.

Polyp: The colour of the living animal is light yellowish-brown.

Variability of the characters in the different biotopes. -

Although the three colonies present in the New Caledonia series come from different biotopes, they are very much alike. The diameter of the small monticules sometimes can be somewhat variable.

Discussion. -

The holotype of Lamarck could not be traced in Paris but this species is so easy to recognize that there hardly exist any controversies about the species in literature. Matthai, 1928, pl. XVII fig. 2 , illustrates the holotype. Besides, the holotype of Hydnophora klunzingeri Rehberg, 1892, is lost (all Rehberg's types were destroyed in the last world war, Dr. S. Gerlach, in litt.). Rehberg remarks (: 22) that his specimens from Samoa differ from Hydnophora microconos in having more dentations on the septa and a smaller columella. I agree with Matthai, 1928: 150, that $\boldsymbol{H}$. klunzingeri is synonymous with $H$. microconos. In literature most records are brief and of zoogeographical importance only. Hoffmeister, 1925: 30, describes one colony from Samoa as an intermediate form between $\boldsymbol{H}$. microconos and $\boldsymbol{H}$. rigida. The specimen has to be examined before conclusions can be drawn.

The species is distributed in the Indian Ocean (Maldives) and throughout the western Pacific.

Hydnophora rigida (Dana, 1846). Pl. XII fig. 4.

Merulina rigida Dana, 1846: 276, pl. 17 fig. 1; holotype USNM No. 148.

Synonyms. -

Hydnophora mayori Hoffmeister, 1925. USNM No. 52723.

?*Hydnophora ramosa Nemenzo, 1959, UP C-392.

Material. -

New Caledonia collection ZMA (2 colonies):

Biotope 3 - Coel. 6004

" 6 - Coel. 6005 .

Other collections:

\begin{tabular}{|c|c|c|}
\hline ZMA & $\begin{array}{l}\text { Coel. } 553 \\
\text { Coel. } 622\end{array}$ & $\begin{array}{l}\text { Makassar (Celebes) } \\
\text { Moluccas }\end{array}$ \\
\hline RMNH & $\begin{array}{l}\text { No. } 1126,1127, \\
1128,1129\end{array}$ & Togian Reef (Celebes) \\
\hline & $\begin{array}{l}\text { No. } 7106 \\
\text { No. } 1889.9 .24 .151\end{array}$ & $\begin{array}{l}\text { Bay of Batavia } \\
\text { Chinese Sea } \\
\text { (unspecified) }\end{array}$ \\
\hline
\end{tabular}

Characters. -

Corallum: Never massive, always branching; the valleys are continuous with an average width of $4 \mathrm{~mm}$. The monticules resemble those of $\mathrm{Hyd}$ nophora microconos, but they are larger (up to $4 \mathrm{~mm}$ in height) and usually conical, but sometimes, especially along the thinner branches, they form ridges. About 12 septa per monticule. Subsidiary septa are present between the principal ones; they slope gently down to the columella. The columella is well developed, forming centres and encircling the monticules.

Polyp: The colour of the living tissue is light brown. 
Variability of the characters in the different biotopes. -

With only two colonies available not much can be said about the interpopulational variation. Coel. 6004 from an inner barrier reef site resembles the holotype of Dana in all details. The other specimen Coel. 6005 from a shallow lagoon site has a lighter structure and narrower branches. The monticules are more irregularly dentated and often form ridges, especially at the outer ends of the branches. This specimen corresponds more closely with Hydnophora mayori Hoffmeister.

\section{Discussion. -}

The holotype of Hydnophora rigida Dana from the Fiji Islands is a small colony with cylindrical branches and conical monticules. The holotype of Hydnophora mayori Hoffmeister, 1925: 30, comes from the Fiji Islands (tidal pool, barrier reef). Hoffmeister mentions the resemblance to Hydnophora rigida, but regards the differences, viz. more dentation on the septa and monticules inclining towards the end of the branches, as of specific importance. Another species closely allied to Hydnophora rigida was recorded by Nemenzo, 1959: 105, as the new species Hydnophora ramosa. Judging from his description and photograph this specimen may also fall within the range of variation of Hydnophora rigida. Some large colonies in other collections e.g. ZMA Coel. 553, RMNH No. 1127, show a great variation within one colony. ZMA Coel. 622 from a lagoon site and RMNH No. 7106 (from the Bay of Batavia), however, are of the pure mayori type. A larger series only can shed some more light on the variation possible within this (these) species and so on the synonymy.

Localities of the species are: Indonesian Archipelago, southern Philippines, Japan (Yabe \& Sugiyama, 1936), New Caledonia, Samoa (Hoffmeister, 1925), Fiji Islands, Marshall Islands (Wells, 1954), Fanning Island (Vaughan, 1918).

\section{Caulastrea Dana, 1846.}

Type species. - Caulastrea furcata Dana, 1846; by subsequent designation Matthai, 1928.

Diagnosis of the genus (after Wells, 1956). Phaceloid colonies produced by mono- to tristomodaeal budding, permanent condition mono- to tricentric. Columella feeble.
The following species are here discussed:

- Caulastrea echinulata (H. Milne Edwards \& Haime, 1849).

Rare. Colony phaceloid, with parallel branches; corallites oval, edge zone about $2 \mathrm{~cm}$, number of the septa about 30, septa broad and well dentated; costae present; paliform structure present, columella twisted, trabecular; polyp brown with green stomodaeum.

- Caulastrea furcata Dana, 1846.

Rare. Colony phaceloid, with divergent branches, corallites rounded to oval, edge zone of a variable length, number of septa about 30 , edges with strong dentation, costae present, columella well developed; polyp brown with green stomodaeum.

- Caulastrea curvata nov. spec.

Rare. Colony phaceloid, with divergent branches, end of branches curving; corallites rounded to oval; edge zone of variable length, septa exsert, average number about 23; costae well developed, intercostal ridges present; columella small; polyp light green.

Caulastrea echinulata (H. Milne Edwards \& Haime, 1849). Pl. XIV fig. 1.

Dasyphyllia echinulata H. Milne Edwards \& Haime, 1849: 265; syntype MNHN.

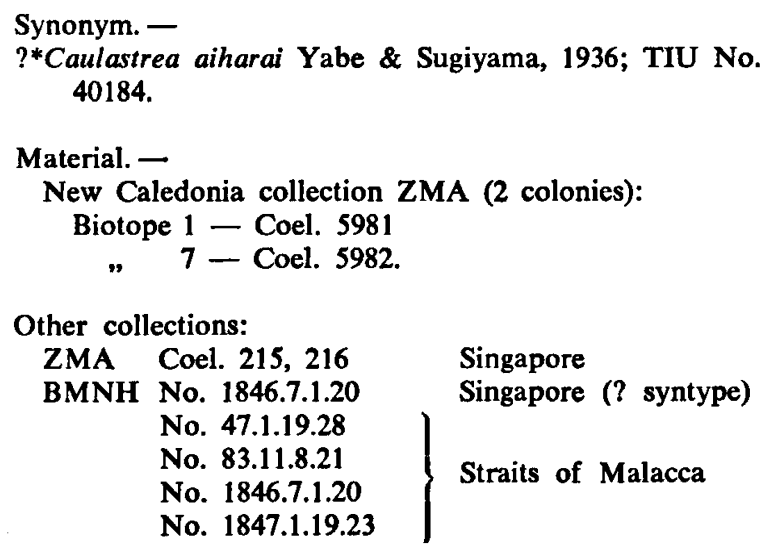

Characters. -

Corallum: The colony is phaceloid, with parallel branches, sometimes fusing. The corallites are usually oval, often distomodaeal or tristomodaeal, the greatest average diameter of a monostomodaeal corallite is $11 \mathrm{~mm}$; the wall is thin, the edge zone about $2 \mathrm{~cm}$ long. The exsert septa, on the average 30 per corallite, are broad and well dentated, the teeth around the columella have a pali- 
form habit; the columella consists of loosely twisted septal trabeculae. The costae are well developed along the whole length of the corallite and irregularly dentated.

Polyp: The colour of the living animal is brown with a green stomodaeum.

Variability of the characters in the different biotopes. -

Characteristic for Caulastrea echinulata is the close setting of the corallites in the phaceloid corallum, because the branches do not diverge. The laterally flattened or even triangular form of the corallites is caused by the lack of space in between each other. In Coel. 5981 the colony has shorter and less parallel branches; the more rounded and irregularly dentated corallites give the colony a more spiny appearance (echinulata type) than Coel. 5982, the latter being a large regular corallum with long parallel branches, that are more regularly built (aiharai type).

\section{Discussion. -}

The syntype of Caulastrea echinulata from Singapore in the MNHN is a rather large corallum with irregular and dentated septa and costae, probably from an exposed niche. The holotype of Caulastrea aiharai from "Enoura-wan" (probably Micronesia) (Yabe \& Sugiyama, 1936: 20) corresponds closely to the New Caledonian bay colony Coel. 5982. The holotype could not be studied but the present synonymy is primarily based on the good original photographs (e.g. pl. XV figs. 1-3).

Matthai, 1928: 275, mentions two specimens in the Paris Museum marked "Dasyphyllia echinulata". BMNH No. 1846.7.1.20 "purchased" probably is one of the two, resembling the other Singapore specimen of $\mathbf{H}$. Milne Edwards \& Haime. The only other record in literature about the present species is by Nemenzo, 1959: 84, of a colony from Cataban Island. His description and photograph are satisfactory.

The species has been recorded from Singapore, the southern Philippines, "Enoura-wan", New Caledonia.

A species closely allied to Caulastrea echinulata is Caulastrea tumida Matthai, 1928: 275. The holotype BMNH No. 28.6.2.1 from Kings Sound, Great Barrier Reef, has been re-examined for the present study. Matthai describes the species as being "heavier than Caulastrea furcata or Cau- lastrea echinulata, branches further apart distally, corallites larger, walls somewhat thicker; septa in single corallites 26-32, costae uniform and continuous". In the New Caledonia collection there are some worn pieces (Coel. 5985) from Baie Dumbéa, coming very close to Caulastrea tumida. Because the material collected is insufficient, I just mention it here without further description.

In my opinion Caulastrea tumida is a valid species, also in view of the many records by Yabe \& Sugiyama, 1936: 19, of this species.

Caulastrea furcata Dana, 1846. Pl. XIV fig. 2.

Caulastrea furcata Dana, 1846: 198, pl. 9 fig. 4; holotype USNM No. 80.

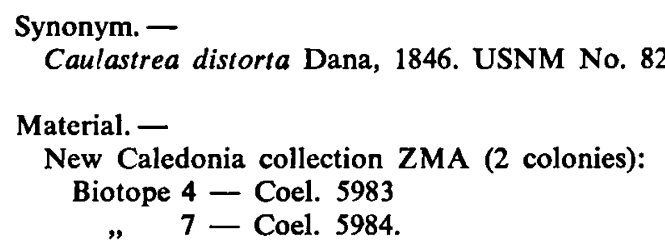

Other collections:

BMNH No. 92.12.4.77 Great Barrier Reef.

Characters. -

Corallum: The colony is phaceloid, with the branches diverging outwards; the corallites are often laterally compressed with an average greatest diameter of $10 \mathrm{~mm}$; the wall is rather thin, covered by an edge zone over a varying distance; the septa are exsert, about 30 in number in monocentric corallites, with irregularly dentated edges, gently sloping down to the bottom of the calyx to fuse with the well developed columella, that consists of loosely twisted trabeculae. The costae, especially at the upper part of the calyx, are strongly developed, becoming rather thin going downwards.

Polyp: The colour of the living animal is brown with a green stomodaeum.

Variability of the characters in the different biotopes. -

The two colonies present correspond in all details with the holotype. Intra-colonial differences are slight.

\section{Discussion. -}

The holotype of Caulastrea furcata from the Fiji Islands is a small colony with a smooth appearance; the septa are regularly exsert and finely dentated, and the costae are present as thin ridges on the edge zone. The holotype of Caulas- 
trea distorta Dana, 1846: 199, also from the Fiji Islands, was regarded synonymous with Caulastrea furcata by Matthai, 1928. I agree with him, the only difference being that the colony has more irregular septa with a stronger teeth formation; the costal ridges are more developed.

In the literature only a few further records exist of this species. Yabe \& Sugiyama mention it from Palau and the Ryukyu Islands, without further description. Their figures, however, are good. Crossland, 1952: 140, gave the second record of Caulastrea furcata from the Great Barrier Reef, and Nemenzo, 1959: 84, provided a good description of the present species, based on a specimen from Cataban Island, southern Philippines. Judging from the delicate phaceloid growth form the species may be supposed to be stenotopic, with a preference for quiet lagoon or bay niches. Therefore, it is not surprising that the records in literature and the specimens in coral collections are so few.

Localities of the species are: Japan, southern Philippines, Palau Islands, Great Barrier Reef, New Caledonia, and the Fiji Islands.

Crossland's (1954: 139) new species Caulastrea simplex is rather a doubious one. The single, solitary specimen has been dredged. I have no specimens corresponding to Crossland's species in my collection.

The only other nominal species in this genus, Caulastrea undulata Dana, 1846: 199, could not be traced in the USNM. Since this species stands for a specimen "probably from the West-Indies", it has been provisionally placed under Eusmilia fastigiata (Pallas) by Matthai, 1928: 272, the more so because Dana himself admitted a great resemblance between his new species and Eusmilia fastigiata.

Caulastrea curvata nov. spec. Pl. XIV figs. 3, 4.

Material and types. -

New Caledonia collection ZMA (4 colonies):

Biotope 5 (Récif Snark, depth $10 \mathrm{~m}$ ) - Coel. 5986 paratype

" 6 (Récif Ricaudy, depth $5 \mathrm{~m}$ ) - Coel. 5987 paratype

" 7 (Baie de Prony, depth $5 \mathrm{~m}$ ) - Coel. 5988 holotype, Coel. 5989 paratype
Characters. -

Corallum: The colony is phaceloid, with the branches diverging outwards, the last part of the branches often curving sidewards or upwards; corallites rounded to oval, with an average diameter of $7 \mathrm{~mm}$. The theca is thin, the edge zone is long, sometimes covering the whole length of the branch; the septa are extremely exsert, up to $4 \mathrm{~mm}$; they are rather thin and finely dentated, their average number is 23 (maximum about 25 , minimum about 20). The principal septa are the most exsert, rounded at the top, they fall steeply down into the calyx, but before fusing with the columella they sometimes form a paliform lobe. The small columella consists of some twisted septal teeth. The costae are well developed and form strong and dentated ridges, sometimes with intercostal ridges on the outside of the wall along the whole length of the branches.

Polyp: The colour of the living animal is light yellowish-brown, with a light green stomodaeum.

Variability of the characters in the different biotopes. -

Coel. 5986 from biotope 5 (wreck of the "Snark") is a small corallum with short branches, that do not curve upwards. The primary septa are irregularly exsert and there is a more distinct dentation than in the holotype (from biotope 7). Coel. 5987, found in biotope 6 at a depth of $10 \mathrm{~m}$ consists of small pieces, and corresponds closely to the colony from biotope 5 . The branches are somewhat stronger developed than in the bay forms. Coel. 5988 and 5989 from a bay site (Baie de Prony), found at a depth of $5 \mathrm{~m}$, are larger coralla with long and curving branches. The specific name was derived from the latter character.

\section{Discussion. -}

The species is related to Caulastrea furcata. Both have diverging branches and a large edge zone, therefore standing apart from $C$. echinulata and $C$. tumida. The main differences from its closest relative (in the same biotope) are: the curved outer ends of the branches, the smaller corallites, the fewer and more exsert septa; and the colour of the polyp. 


\section{CHAPTER IV. ECOLOGY}

\section{A. Discussion of the environmental influences.}

Several systematists have commented upon the occurrence of growth forms in corals, but a causal correlation with environmental factors was only rarely made. Even the conclusions of the present paper are hypothetical in some degree since the factors were not measured in the field. Some published work about the intraspecific variability in relation to the environmental factors will be discussed below.

Vaughan, 1918, in his study about some shoal water corals from Murray Island (Australia), Cocos Keeling Island and Fanning Island often refers to the ecological work done by Mayer (1918). Since Vaughan was at that time a very experienced coral taxonomist and since he used these ecological data, his work is very important. Of many species he mentioned the exact place where the specimens were collected. The variability of some species is described in full, e.g. of Goniopora tenuidens (Quelch). Favia pallida is divided into six "facies types", corresponding to the variation seen in the New Caledonia series from biotopes 2,3 , and 4. Vaughan does not discuss the correlation between the morphology and the habitat.

Boschma, 1924, remarked that "in many species of reef corals the form of different colonies is largely subject to external influences that affected it during its growth". Even intracolonially this variability can be found. In Boschma's (1948) revision of Millepora Linnaeus, 1758, he comments upon the occurrence of external modifications, as well as on the criterium that two forms must constitute full species when they can be found side by side in the same environment.

Hoffmeister, 1925, in his study of the corals from Samoa and the Fiji Islands came to the conclusion that because one is often in doubt about the identity of a specimen it would be easier to indicate both species of which it combines the characters, e.g. Leptoria phrygia $\rightarrow$ gracilis.

Umbgrove (1940) later on followed this example. In his paper on the Madreporaria from the Bay of Batavia, Umbgrove (1939) divides the reef in 6 facies-types. Generally speaking, these cover a gradient from the fringing reef towards the sea. Umbgrove had of most species only a few representatives generally coming from the same facies. Since with these small series he undertook a systematic study of all corals present, habitat induced variability could not show up clearly. The area of the Togian Reef, Gulf of Tomini, North Celebes (Umbgrove, 1940) comprises more different ecological possibilities: a barrier reef, a lagoon and fringing reefs being present. Because his series are somewhat larger and from more diverse habitat conditions, more transitional forms are present and therefore sometimes growth forms (ecotypes) could be recognized (e.g. halicora $\rightarrow$ hemprichi; rustica $\rightarrow$ astreiformis).

In his last paper, Crossland (1952) commented on a large collection from the Great Barrier Reef. Because of his lifelong experience with corals he took the environmental influences into account; there are cases of variation within one species, which seem hard to believe, but which are clearly proved by the series examined. His contribution to coral taxonomy is very sound. For instance, he normally based his species on series of coralla. But as he was dealing with 174 species, the series of many variable species are not large enough to distinguish the ecotypes.

Wells, 1954, in the introduction of his large work about the recent corals of the Marshall Islands, gave a zonal analysis of the coral fauna. Under Favia pallida (: 457) he recognized four different facies types differing in the size of the calyx, the separation of the corallites, and the relative thickness of the septa. The specimens have been studied by me in the USNM. Nineteen specimens of formae 1 and 2, both from the seaward reef, did not show much difference, just some intrapopulational variation corresponding to the New Caledonia series from biotope 2 (and facies 3 of Vaughan, 1918). Four specimens of forma 3 came from the lagoon or reef flat corresponding with the New Caledonia series from biotopes 3 and 4 (and facies 4 of Vaughan, 1918). No specimens of forma 4 were available, that according to Wells' description had still larger corallites that were more than $3 \mathrm{~mm}$ separated from each other. Wells remarked "confirmation of any correlative significance to these variations, however, is lacking". Probably since one needs series from a wide range of different biotopes (as long as the habitat factors are defined qualitatively only), before one is able to see any consistent correlation between variability and environment, Wells did not find this relation. The reefs of the Marshall Islands have fringing reefs and a large reef flat. Therefore, the variability within one species will be less pronounced. Wells commented on even more coral species than Crossland, and therefore, his series are as a rule not large enough. 
These are some of the systematic coral studies that take environmental factors, on which the growth forms are so dependent, into account. Gardiner (1902) admits that the distinction of species or varieties requires "the examination of thousands of specimens, and that it is a task of Herculean proportions". In the present paper, however, series of only a limited group of corals are studied.

Other authors have tackled the question of relation between skeleton deposit and light influence from the physiological side, mostly not knowing the extent of variability of the species they studied. Their data only seldom concern Faviinae, but they confirm strikingly that more light is positively correlated with an increase in the skeleton deposit.

Goreau, 1959, using radioactive calcium as a tracer, measured the deposition of calcium carbonate in the tissue in relation to light. Illumination increases the rate of calcification, especially when zooxanthellae are present. Goreau supposed that the key role of symbiotic algae, living in the outer layers of the tissue, is the removal of $\mathrm{CO}_{2}$ (which they use for their photosynthesis) from the deeper layers, where calcification takes place by a conversion of bicarbonate into carbonate. It is interesting that even in the dark, corals with zooxanthellae show more calcification than those that have lost them. This may point to a general role of the algae as consumers of coral metabolic waste products. Water action will bring about more oxygenation, but, especially, will help with the removal of waste products as well (Yonge, 1968).

An ingenious hypothesis is the one brought forward by Roos (1967) that, although the total light energy seems to be of primary importance, it is essentially the local light intensity on the coral that is growth limiting. In this way he shows that Porites astroides of greater depth has to be flat to receive a minimum quantity of light on every corallite sufficient to stimulate photosynthesis and consequently oxygen production to a point in which it compensates the oxygen consumption needed for growth.

Weber \& Woodhead (1970) underline the function ascribed to the zooxanthellae by Goreau: "intracellular lungs and kidneys". The importance of the removal of metabolic waste products other than $\mathrm{CO}_{2}$ is stressed; especially phosphates can prevent $\mathrm{CaCO}_{3}$ precipitation. Since corals in deeper water contain less zooxanthellae (Yonge,
1940; Best, 1969) in deeper or darker water less calcification may be expected.

\section{B. The plasticity of the skeleton.}

The hypothetical relation between a coral's morphology and the environment was tested by Best (1968). From sites intermediate between two typical habitats specimens were collected with a morphology intermediate between two presumed species. Therefore, it was concluded that a coral should be "reconstructed to its diagrammatical form", the latter concept showing the characters of the species.

For gauging the environmental factors influencing growth, a wealth of apparatus has been developed. There is a tremendous variation among the micro-habitats on the reef. A physiologist measuring a number of factors may find great differences on sites a few decimetres apart, which explains the remarkable intracolonial morphological variation. The general results of these experiments can be used for taxonomic work, because in the major habitats of the reef area the influence of the important environmental factors is, statistically spoken, fairly constant.

For instance, although an occasional corallum may struggle for life in the shadow of a large colony of Millepora, yet we may generalize that on the fringing reef there is plenty of light for coral growth. Each of the seven biotopes into which the New Caledonian reef area is divided for the purpose of this study can be more or less defined ecologically in a qualitative way. Faced with the richness of the Indo-Pacific reef, one has to be content for the moment with this kind of ecological description; physiological-ecological studies on the intrapopulation level to investigate the supposed conditions quantitatively, can follow only after the several growth forms have been grouped into biological species.

The larva of a species, having the so-called "specific diagram" genetically determined, will have a certain degree of phenotypical modification superimposed, depending on the site where it settles. It may safely be supposed that the larvae are randomly distributed throughout the reef area (Wells, 1957 b). Several species have been found in all seven biotopes. The environment-induced modifications per biotope tend to follow the same pattern in the whole of the subfamily.

The skeleton of the Faviinae has several functions. Members of this subfamily are stoutly built, with great resistance to wave action. On such ex- 
posed sides prevail conditions with much light, food and oxygen. An increase in skeleton deposit under these conditions brings about an increase in the number of corallites (three-dimensional growth; Goreau, 1963). This larger number of corallites can be arranged more profitably on the surface of a hemi-sphere, than on a flat, encrusting growth form (cf. Goreau, 1963, fig. 9). In a shallow exposed area small and deep corallites give the living tissue more grip and protection. Under more sheltered, less favourable conditions, the growth will be flat (so called two-dimensional). In the sandy lagoon and bays, where there is more sedimentation, the polyps have to be larger to be able to remove the sediment, so the calices are shallower and larger and if possible the growth form is "higher" (plocoid becomes phaceloid; cerioid becomes hillocky). The dentation may again be an adaption for giving more grip to the living tissue. Red Sea specimens, for instance, have a smoother habit than their ocean relatives generally living under more exposed conditions (Gardiner, 1904).

As to the different growth forms some general observations may be made. Plocoid Faviinae (genus Favia) are the commonest of the group and seem to be the best adapted even to adverse conditions. In bays plocoid colonies are able to grow upwards, assuming a phaceloid or even subdendroid form; under such conditions one finds them together with the dendroid Caulastrea. The corallites of the cerioid genus Favites, not able to grow upward individually, grow upward together, resulting in a typical hillocky habit.

The fastest growth can be expected in the meandroid corals, where each individual corallite has to build a minimum of skeleton wall. Hydnophora is a genus that can be considered a bizarre, but rather successful expression of the meandroid type.

\section{Environmental factors influencing coral growth.}

In the introduction to the systematic part of this paper, light, temperature, salinity, exposure, and sedimentation have been mentioned as the main factors conditioning coral growth. It has been explained what effects will accompany an increase of depth: the light diminishes, and temperature and wave action decrease. All these factors result in a decrease in skeleton deposit, partly by the deterioration of the conditions, partly because there is no advantage in having a strong structure.
Around the barrier reef the water is richly oxygenated. On the lee side there is less wave action, and more sedimentation. On the windward side the breakers force the coral to grow as stoutly built coral heads. In the lagoon Faviinae are scarce, and if present adapted to the removal of the sediment; the conditions of light and oxygenation are suboptimal. Near the coast normally fringing reefs are found, where corals live on sand or on dead coral substatum. In New Caledonia often large bays are present, usually with the mouth of a river, carrying much sediment. Even when the water is not so deep, light is scarce in the turbid water. The unusual character of such a habitat is described in Wijsman-Best, 1970. This situation: bays in a mountainous island is not common in the Pacific, but occurs e.g. in the Philippines (Nemenzo, 1955).

The fringing reef and the island reefs (biotope 5) seem the most normal habitats. However, they cannot straightly be compared with fringing reefs elsewhere, that will have a character intermediate between the biotopes 2 and 6 when protection against the ocean breakers is absent. In smaller seas, like the Red Sea, fringing reefs will have a biotope 6 character (Gardiner, 1904). Large reef flats, with a calcareous algal ridge (several examples in Wells, 1954), are not present in New Caledonia.

From the above it follows that certain predictions can be made about the type of modification of the morphology of the Faviinae in the different biotopes. It is expected that the amount of skeleton deposit will decrease in relation to greater depth. In the richly oxygenated water around the barrier reef (biotopes 1 and 2) there will relatively be more skeleton deposit. The latter can be expressed as number of septa per corallite or as number of corallites per square unit. Both numbers are variable in one corallum, but representative sides have been chosen and the number of septa is the mean out of 10 corallites counted. In meandroid corals it is of no use to speak of corallites; the number of septa per length of valley probably is not so clearly correlated with the skeleton deposit, since meandering can be regarded an adaptation to faster growth, since less skeleton has to be formed per unit of living tissue. Nevertheless, the septa in the valley are calcareous and can be expected to be more numerous under optimal light and oxygen conditions.

Of 6 species the number of coralla collected was sufficiently large to allow graphical treatment: 
Favia favus, Favia speciosa, Favites pentagona, Goniastrea pectinata, Goniastrea australensis, and Platygyra daedalea.

In the first three of these the number of septa and the number of corallites have been plotted against the water depth (figs. 6, 7, 8, 9, 10, 11, respectively). In the latter three the number of septa per $10 \mathrm{~mm}$ and the maximum number of corallites per meander have been plotted against the water depth (figs. 12, 13, 14, 15, 16, 17, respectively).

An inverse correlation between skeleton deposit and depth seems apparent, as well as a higher level of skeleton deposit in more oxygenated water and this relation holds true for all the different colony forms of the Faviinae. This pattern of morphological change is borne out in species with smaller series (10 to 20 specimens) as well: Favia pallida, Favia amicorum, Favia valenciennesi, $F$ a. vites melicerum, Favites chinensis, and Favites virens.

\section{Ecotypes in the Faviinae.}

The extrapolation seems justified that the relation between biotope and skeleton morphology established in six abundant species and six less numerous ones, holds true all over the subfamily. Therefore, even when very few specimens have been collected from different biotopes, they can be compared to see whether they conform to the predicted modifications of a given specific diagram. Morphological groups from the same biotope, separated by a gap, represent as many species, regardless of specimens from a different environment that bridge the gap. Next, the ecotypes from different biotopes must be interrelated; and because there are normally some atypical specimens from a micro-habitat with the characters of another biotope, it can be deduced which series of ecotypes constitutes a biological species.

In this way some interesting conclusions have been drawn: that Favia eridani is the fringing reef form of Favia valenciennesi; that Bikiniastrea laddi is the bay form of Favia amicorum; that Favites ellisiana and Favites halicora are the barrier reef forms of Favites virens and Favites abdita, respectively. Apart from disturbances of the general pattern by local influences of the microenvironment, these forms replace each other in different biotopes, while the relation between them is the one expected from the experience with, for instance, Favia speciosa. The latter species is so numerous in collections that there are enough specimens present bridging the gaps between the ecotypes, preventing their separation under specific names. In all species ecotypes can be distinguished, of which a summary follows here. For a better understanding the sites have been generalized.

- Favia favus from a fringing reef (biotope 6), has the ecotypes crassidens from a more exposed reef site (biotope 2) and cavernosa from a more quiet lagoon site (biotope 4) and an as yet undescribed very atypical bay-form (biotope 7).

- Favia speciosa from a lagoon site (biotope 4) has the ecotypes pandanus from a more exposed reef site (biotope 2) and puteolina from a more sheltered reef site (biotope 3 ).

- Favia pallida from a lagoon site (biotope 4) has an ecotype doreyensis from a sheltered reef site (biotope 3 ).

- Favia amicorum from a lagoon facies (biotope 4) has an ecotype laddi from a bay site (biotope 7).

- Favia valenciennesi from a lagoon facies (biotope 4) has the ecotypes irregularis from a shallower lagoon site (biotope 4 , at more than $10 \mathrm{~m}$ depth) and eridani from a fringing reef site (biotope 6).

- Favia stelligera from an exposed reef site (biotope 2) has the ecotype lobata from a more sheltered reef site (biotope 6) and fanningensis from a lagoon site (biotope 4).

- Favia laxa from a lagoon site (biotope 4) has an ecotype helianthoides from a reef site (biotope 2).

- Favites pentagona from a sheltered reef site (biotope 3) has the ecotypes deformis from a more exposed reef site (biotope 2) and gibbosissima from a fringing reef site (biotope 6).

- Favites melicerum from a lagoon site (biotope 4) has an ecotype laxa from an exposed reef site (biotope 2).

- Favites chinensis from a deep barrier reef site (biotope 1) has an ecotype (complanata Yabe \& Sugiyama non complanata Klunzinger) from a lagoon site (biotope 4).

- Favites acuticollis from an exposed reef site (biotope 2) has the ecotypes yamanarii from a more sheltered reef site (biotope 3 ) and profunda from a bay facies (biotope 7).

- Favites abdita from a fringing reef site (biotope 6) has the ecotypes halicora from a deep barrier reef site (biotope 1) and robusta from a more exposed barrier reef site (biotope 2) and 
fusco-viridis from a more sheltered reef site (biotope 3).

- Favites virens from a fringing reef site (biotope 6) has an ecotype ellisiana from an exposed reef site (biotope 2).

- Goniastrea retiformis from an exposed reef site (biotope 2) has an ecotype parvistella from a more sheltered reef site (biotope 3 ).

- Goniastrea spectabilis from an exposed reef site (biotope 2) has an ecotype mantonae from a more sheltered reef site (biotope 3).

- Goniastrea favulus from a sheltered reef site (biotope 3) has an ecotype aspera from a fringing reef site (biotope 6).

- Goniastrea pectinata from a sheltered reef site (biotope 3) has the ecotypes planulata from a deeper reef site (biotope 1) and multilobata from a fringing reef site (biotope 6).

- Goniastrea australensis from an exposed reef site (biotope 2) has the ecotypes benhami from a more sheltered reef or lagoon site (biotopes 3,4 ) and equisepta from a bay site (biotope 7).

- Platygyra lamellina from an exposed reef site (biotope 2) has an ecotype leptotichus from a lagoon site (biotope 4).

- Platygyra daedalea from an exposed reef site (biotope 2) has the ecotypes esperi from a shelterod reef site (biotope 3) and astraeiformis from a lagoon site (biotope 4).

- Leptoria phrygia from an exposed fringing reef site (biotope 6) has an ecotype gracilis from a deeper reef site (biotope 1).

- Hydnophora exesa from a shallow but sheltered reef site (biotope 3) has the ecotypes grandis from a lagoon site (biotope 4), maldivensis from a bay site (biotope 7) and tenella from a deeper reef site (biotope 1).

The modifications into different ecotypes are as expected from their habitat, on the basis of the relation between environment and calcium deposit as established. $\boldsymbol{F}$. amicorum and $\boldsymbol{F}$. valenciennesi can be considered stenotopic, as already indicated in the description of the species, but although they are mostly found in lagoon and bay facies they still occur occasionally in the reef facies.

The following species are not mentioned in the list because they are scarcelv represented: Favia matthai; Favia rotumana; Favites rufa; Favites palauensis; Oulophyllia crispa; Hydnophora microconos; Hydnophora rigida; and all species of Caulastrea.

E. The ecological distribution of the species.
The number of individuals per surface unit of habitat for each species could not be counted, since lack of field characters prevented identification on the reef. One may ask how far the number of specimens collected reflects the relative abundance within the entire community. This would be so if collecting had been done at random, but it was not. Originally, a specialized study of Favia (and Favites) was planned, so the other genera have not been collected with the same fer: vour. Secondly, some corals appear to have been more common in the field than in the collection, although this can be said only when the polyp had a special colour or form (in a certain biotope), and because easily recognized, was not collected again and again, e.g. Favia favus in biotope 7; Favites abdita in biotope 6; Leptoria phrygia in biotope 2; Hydnophora microconos in biotope 3 . A few species are stenotopic: Favia valenciennesi, preferring a lagoon or bay biotope, and, very seldom a reef habitat (eridani form); Favia amicorum, also preferring the lagoon and bay biotope; various species of Caulastrea, occurring in quiet reef niches but more common in the bay. The great majority of Faviinae seems to be adapted to every biotope available in the reef area. Several of the sympatric species have the nature of sibling species, e.g. Favia pallida - F. speciosa; Favia stelligera $-F$. laxa; Favites abdita $-F$. virens $-F$. flexuosa; Favites pentagona $-F$. melicerum $F$. rufa; Platygyra daedalea $-P$. lamellina. The influence of competition presents a very difficult problem in corals, as in sedentary animals in general. It is by no means easy to define in what way every species has its own ecological specialization, if it has any. There certainly is competition for space; whether there is competition for food cannot be said as yet, improbable as it seems to be in view of the abundance of zooplankton.

It follows that not much can be said in quantitative terms about the presence of the corals collected, in particular the Faviinae, in the different biotopes. This applies mainly to the reef biotopes. In the sequel, in the general biotope discussion, many names of the coral genera collected in New Caledonia will be used. First a list of these will be given, together 59 genera, in five suborders.

\section{Astrocoeniina:}

Stylocoeniella, Psammocora, Stylophora, Seriatopora, Pocillipora, Acropora, Astreopora, Montipora, Anacropora.

Fungiina:

Pavona (Polyastra, Pseudocolumnastrea), Leptoseris, 
Pachyseris, Coscinaraea, Cycloseris, Fungia, Herpolitha, Polyphyllia, Halomitra (Parahalomitra), Goniopora, Porites, Alveopora.

Faviinae:

Caulastrea, Plesiastrea, Favia (Bikiniastrea, Barabattoia), Favites, Oulophyllia, Goniastrea, Platygyra, Leptoria, Hydnophora, Diploastrea, Leptastrea, Cyphastrea, Echinopora, Trachyphyllia (Callogyra), Culicia, Galaxea, Acrhelia, Merulina, Homophyllia, Acantastrea, Acanthophyllia, Blastomussa, Lobophyllia, Symphyllia, Echinophyllia, Mycedium, Pectinia, Cynarina. Caryophylliina:

Polycyathus, Heterocyathus, Desmophyllum, Euphyllia, Plerogyra.

Dendrophylliina:

Balanophyllia, Dendrophyllia, Heteropsammia, Turbinaria, Tubastrea.

In biotope 1 , extending from the outer reef terrace (at a depth of about $20 \mathrm{~m}$ ) down to $50 \mathrm{~m}$, more fragile and branching genera or adapted growth forms of representatives of a more exposed reef facies, e.g., of the genera Favia, Favites, Acanthastrea have been found. Characteristic genera, in addition to the numerous fragile forms of Acropora and Porites, are Seriatopora, Leptoseris, Pachyseris, Merulina, Echinophyllia, Mycedium, Balanophyllia, Dendrophyllia, etc.

Below a depth of $50 \mathrm{~m}$ coral growth becomes scarcer: thin foliaceous Leptoseris colonies and branching Dendrophyllia colonies were observed, but not collected. Special attention was paid to some deep caves situated at a depth of about 30 to $40 \mathrm{~m}$ on the southern New Caledonian barrier reef. A special coral fauna, also including some ahermatypic deep-sea corals, was found there, about which a separate account will be published in the future.

Biotope 2 is the reef facies with the most luxurious coral growth. On the reef terrace an intermediate zone is found between biotope 1 as described above and the upper zone, exposed to the heavy ocean surf. Not fixed species of Fungia and Herpolitha are present along with the more branching or fragile representatives of Plesiastrea, Favia, Favites, Leptastrea, Echinopora, Galaxea, etc. In the upper $20 \mathrm{~m}$ of the reef slope the colonies are all strongly built, spherical or plate-like. Large heads of Coscinaraea, Porites, Favia, Platygyra, Diploastrea are present; on specific level, forma crassidens of Favia favus, forma pandanus of Favia speciosa, forma robusta of Favites abdita, and forma ellisiana of Favites virens. On the barrier flat reef itself, only occasional collecting was done as the waves were heavy. Here the well known "negro heads" and corals that can withstand a regular emersion are found.

At the inner side of the barrier reef, in biotope 3, a rich coral fauna was found, although in general still less dense and less diverse. Large banks of Acropora and Porites were seen. In addition to these common species others, adapted to quiet surroundings are present, such as Hydnophora rigida, Galaxea fascicularis, Acrhelia horrescens, Merulina laxa, Tubastrea heronensis, and the growth forms of quiet water, e.g. forma puteolina of Favia speciosa, forma esperi of Platygyra daedalea, forma gyrosa of Hydnophora exesa, as well as the genera Montipora, Leptastrea, Cyphastrea, Lobophyllia, Symphyllia, Desmophyllum, Dendrophyllia. Towards the sandy lagoon the coral growth becomes scarcer, the genera present in this area are, for example, Pavona, Pachyseris, Goniopora, Alveopora, Symphyllia, Pectinia, Plerogyra, as well as the following adapted growth forms: forma speciosa of Favites speciosa, forma benhami of Goniastrea australensis, forma grandis of Hydnophora exesa. A characteristic lagoon facies at depths between about 20 and $30 \mathrm{~m}$ consists of Cycloseris spec., Fungia distorta, "Fungia patella", Trachyphyllia geoffroyi, Heterocyathus spec., Heteropsammia spec. and Turbinaria crater, all well adapted to remove sand (cf. Goreau \& Yonge, 1968). Favia amicorum forma laddi and Favia valenciennesi (lagoon form) are sometimes present. Once, some colonies of Leptoseris papyracea were collected. A remarkable thing is the competition seen between Cycloseris and Heteropsammia, both present in large quantities, but always with either the one or the other in a dominant position. Heterocyathus was much rarer. Another observation was made on the common lagoon species Trachyphyllia geoffroyi, showing an extremely large variation in colour. In shallower and more quiet lagoon waters Trachy. phyllia forms larger and more meandroid colonies, coming close to "Callogyra".

The fringing reefs around the lagoon islands and along the New Caledonian coast do not differ much from the barrier reef facies. Coral growth is less abundant and the growth forms are less strongly built. More fragile species of Acropora are present, Astreopora, Halomitra, Echinophyllia, Pectinia, and Turbinaria do occur as well. A special coral community, capable of removing sediment, is found in the bays; reasons for this special adaptation will be discussed below. Most of the species generally present in quiet water are found, e.g. Hydnophora hystrix, Acrhelia horrescens, Eu- 
phyllia picteti, Turbinaria crater, and representatives of the genera Madracis, Leptoseris, Cycloseris, Caulastrea, Echinopora, Echinophyllia, Mycedium, Pectinia, Dendrophyllia. Characteristic are Alveopora catalai, Blastomussa merleti, and Cynarina cynarea. The coral growth in these bays is remarkably rich. The bottom consists of mud and sand, the light is scarcer than in the lagoon because of the turbidity of the water. In spite of these conditions the coral species flourish and small reefs are formed.

Some favourable factor must compensate for the lack of light. In Baie Dumbéa a number of salinity and water movement measurements were carried out by Mr. J. Launay (geologist of the ORSTOM Institute of Oceanography). The salini-

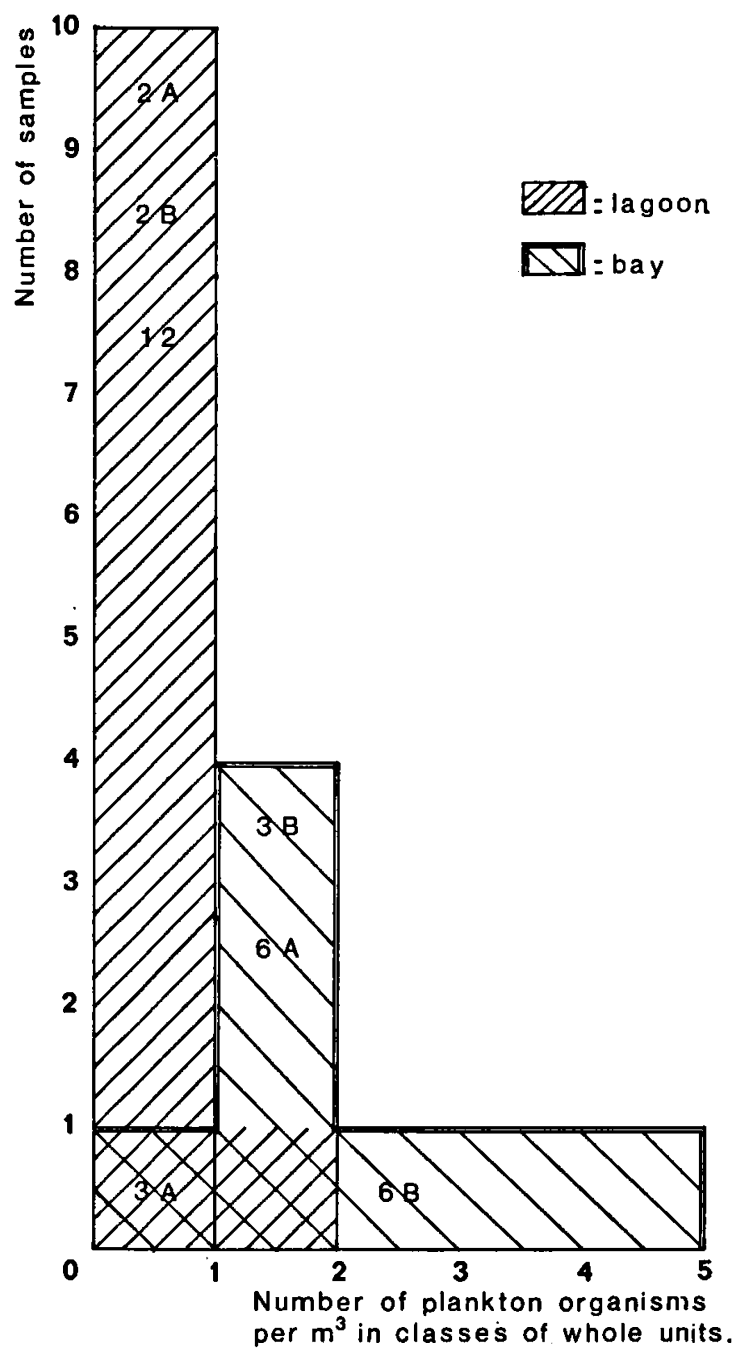

Fig. 18. Diagram of the number of plankton organisms/ $\mathrm{m}^{3}$, based on table $\mathrm{I}$.

Indicated are intermediate situations. ty was about $35.5 \%$ (the same as in the lagoon and near the barrier reef); the water movement was nil. It seems likely that the rivers bring about a local accumulation of nutrients and consequently a local abundance of plankton. Mr. A. Michel was so kind to place some results of the ORSTOM Oceanographic Program at my disposal and to send plankton samples. These were kindly examined by Dr. S. van der Spoel, of the Institute of Taxonomic Zoology, University of Amsterdam. From table 1 it appears that the bays are richer in plankton than the lagoons (see fig. 18), at least in phytoplankton. Though this may be a temporary outburst, to be followed by zooplankton development, it fits the idea that a favourable factor allowing such an abundant coral growth in the bays is the presence of enough food.

In the quiet water of these bays corals capable of removing sediment thrive, so branching corals and dendroid corals are dominant. Only those plocoid corals that are adapted, having large superficial polyps can survive (e.g. bay forms of Favia favus). The bays are protected against the strong tidal current of the lagoon, thus providing another opportunity to many fragile species. A special case is formed by "Banc Gail" (depth 30 to $35 \mathrm{~m}$ ). Here again, a local abundance of corals is found, mainly of the bay forms; yet we cannot properly speak of a bay. But three rivers discharge into the sea at points nearby, and apparently local currents are such that nutrients are concentrated near the shore. Luxurious coral growth in muddy, turbid water has been reported before. Umbgrove (1928) and Verwey (1932) discussed the coral growth in the Bay of Batavia, Nemenzo (1955) gave an account of the scleractinian corals of certain bays in Quezon (southern Philippines) and recently Roy \& Smith, 1971, have published a paper on the sedimentation and coral reef development in turbid water in Fanning Island, the water being extremely rich in plankton.

Most of the conclusions of the present chapter are provisional. Even the relation between skeleton and habitat has been extrapolated from a small number of species. It has been a clear advantage that a whole subfamily has been treated, allowing generalizations even when based on a small series of the species in question. Physiological research based on a study of a well-defined species can strengthen and extend the theory defended on the one hand. On the other hand synecological work is needed to define the relations between the intricate species associations found. 


\begin{tabular}{|c|c|c|c|c|c|}
\hline Site & $\begin{array}{c}\text { P } \\
(\mu \text { gr. }\end{array}$ & $\begin{array}{c}\mathbf{N} \\
\text { (nitrite }+ \text { nitrate) } \\
(\mu \text { gr. atome } / 1)\end{array}$ & plankton $/ \mathrm{m}^{\mathrm{s}}$ & $\begin{array}{l}\mathbf{L}=\text { lagoon } \\
\mathbf{B}=\text { bay }\end{array}$ & $\begin{array}{l}\text { date } \\
\text { (day, month, } \\
\text { year) }\end{array}$ \\
\hline $\begin{array}{r}\mathbf{A} \\
\mathbf{B}\end{array}$ & $\begin{array}{l}0.15 \\
0.00\end{array}$ & $\begin{array}{l}0.06 \\
0.06\end{array}$ & $\begin{array}{l}0.83 \\
1.06\end{array}$ & $\mathbf{L}$ & 14.I.1971 \\
\hline $\begin{array}{r}2 \mathrm{~A} \\
\mathrm{~B}\end{array}$ & $\begin{array}{l}0.00 \\
0.00\end{array}$ & $\begin{array}{l}0.02 \\
0.12\end{array}$ & $\begin{array}{l}0.25 \\
0.71\end{array}$ & L/B & 14.I.1971 \\
\hline $\begin{array}{r}3 \mathbf{A} \\
\mathbf{B}\end{array}$ & $\begin{array}{l}0.00 \\
0.06\end{array}$ & $\begin{array}{l}0.25 \\
0.25\end{array}$ & $\begin{array}{l}0.19 \\
1.08\end{array}$ & $\mathrm{~B} / \mathrm{L}$ & 14.I.1971 \\
\hline $\begin{array}{r}4 \mathrm{~A} \\
\mathrm{~B}\end{array}$ & $\begin{array}{l}0.05 \\
0.11\end{array}$ & $\begin{array}{l}0.26 \\
1.16\end{array}$ & $\begin{array}{l}1.50 \\
3.00\end{array}$ & B & 14.I.1971 \\
\hline $\begin{array}{r}5 \mathrm{~A} \\
\mathbf{B}\end{array}$ & $\begin{array}{l}0.00 \\
0.06\end{array}$ & $\begin{array}{l}0.20 \\
0.11\end{array}$ & $\begin{array}{l}4.55 \\
1.32\end{array}$ & B & 14.I.1971 \\
\hline $\begin{array}{r}6 \mathbf{A} \\
\mathbf{B}\end{array}$ & $\begin{array}{l}0.09 \\
0.09\end{array}$ & $\begin{array}{l}0.06 \\
0.10\end{array}$ & $\begin{array}{l}1.41 \\
2.66\end{array}$ & $\mathbf{B} / \mathbf{L}$ & 14.I.1971 \\
\hline $\begin{array}{l}12 \mathrm{~A}+\mathrm{B} \\
13 \mathrm{~A}+\mathrm{B} \\
14 \mathrm{~A}+\mathrm{B} \\
15 \mathrm{~A}+\mathrm{B} \\
16 \mathrm{~A}+\mathrm{B} \\
17 \mathrm{~A}+\mathrm{B} \\
18 \mathrm{~A}+\mathrm{B}\end{array}$ & & & $\begin{array}{l}0.30 \\
0.77 \\
0.46 \\
0.45 \\
0.71 \\
1.00 \\
0.17\end{array}$ & $\begin{array}{l}\mathbf{L} / \mathbf{B} \\
\mathbf{L} \\
\mathbf{L} \\
\mathbf{L} \\
\mathbf{L} \\
\mathbf{L} \\
\mathbf{L}\end{array}$ & $\begin{array}{l}\text { 7.XI.1966 } \\
\text { 7.XI.1966 } \\
\text { 7.XI.1966 } \\
\text { 7.XI.1966 } \\
\text { 7.XI.1966 } \\
\text { 7.XI.1966 } \\
\text { 7.XI.1966 }\end{array}$ \\
\hline
\end{tabular}

Table I. Abundance of plankton in New Caledonia coastal waters.

(Data of Mr. A. Michel, plankton was examined by Dr. S. van der Spoel.)

$A=$ surface

$1-3=$ Baie Dumbéa

$\mathbf{B}=$ bottom

4-6 = Baie Bulari

$12-18=$ Between Nouméa and

Baie de St. Vincent

Plankton is expressed as number of organisms per $\mathbf{m}^{3}$. On January 14, 1971 a net was used with an aperture of $57 \mathrm{~cm}($ mesh $200 \mu$ ), on November 7, 1966 a net was used with an aperture of $50 \mathrm{~cm}$ (mesh $330 \mu$ ). In all sites except 5 , the bottom is richest in plankton. Site 5 is the only one in which the surface is richer in nitrite/nitrate and plankton.

\section{CHAPTER V. DISCUSSION}

\section{A. Criteria for the delimitation of the taxa.}

The idea has been brought forward that it is possible to identify a specimen by allowing for the general way in which a "typical" form is modified by its environment. But once set apart as a biological unit, such a species normally can be defined by classical, morphological characters. For example, Favites abdita, in the wide sense used here, has always smaller corallites than Favites virens, although it only makes sense to record the diameter in connection with the habitat. But characters of a conservative type also emerge: the paliform structure in Favia pallida, for instance distinguishes the species from its closest relative Favia speciosa. In this way it is possible as a rule to identify old museum specimens without ecological data, allowing us to make use of all the old specific names, based as they normally are on a single old type. Attention has been paid to the warning of Crossland (1952) not to regard two species as growth forms until is has been proved that they constitute one species. Most of the synonyms proposed in this paper are linked by transitional forms or are extremes of one series, e.g. Platygyra astreiformis $-P$. daedalea and Favia valenciennesi $-F$. eridani, respectively. In some cases the synonymy is based on extrapolation of the general aspect seen in larger series of other species, 
but a logical conclusion in view of the preceding literature, e.g. Favites ellisiana $-F$. virens or $H y d n o p h o r a$ tenella $-H$. maldivensis $-H$. grandis - H. gyrosa. There are three synonyms based mainly on extrapolation: Favia laxa $-F$. helianthoides; Favites abdita - F. halicora, and Goniastrea favulus - G. aspera. The possibility cannot be excluded that, on the basis of larger series or a physiological study some of the latter synonyms will prove to be separate species, with a different environmental optimum.

The ecological criterion used in the present paper should of course never be taken too absolutely. Not only is the environment different within the wide area where Faviinae are found, but also the genotypes could show geographical variation. When grown under exactly the same conditions, subspecific differences between populations might be revealed.

Matthai's attempt to find conservative characters in the anatomy of the polyp is worth mentioning; but the results must be considered poor, since the only real separation Matthai could make concerns groups of genera, subfamilies in the present system, and is of a statistical nature too. In the description of the individual species attention to their internal anatomy is paid, but here again a great variation is found, the specific characters show a great deal of overlap, and are based on small numbers of polyps. Nevertheless, in view of the difference in the number of subsidiary couples of mesenteria between Favites abdita and Goniastrea retiformis, an anatomical study of the species that seem intermediate between the two genera would be interesting.

It is a great support for the present system that in some cases there is a close correlation between skeleton characters, considered to be of specific importance, and the colour of the living polyp. It is true that many corals are polymorphic as to colour; some striking examples are given by Crossland, 1952, and Best, 1969. It is difficult to see how colour polymorphism in corals is maintained in nature. But pigments of a different colour may differ only slightly in their chemistry and can have a simple genetic basis. That simply a colour morph would also show a complex of special skeleton features is highly improbable. It is more likely that colour differences may be used as specific field characters, for instance in Favia rotumana, Favia matthai, Favia valenciennesi, Favites melicerum, Favites rufa, Favites palauensis, Caulastrea curvata.
The fluorescence of the living tissue under ultraviolet light can in some cases add a special character too; for instance the red pigment in Favia matthai and Favites rufa and the green pigment in Favia speciosa and Platygyra daedalea. However, colour would be a difficult criterion to be used throughout the range of the species, if in corals the same situation would be present as Czygan \& Seefried (1970) claim to have found in Actiniaria; in Mediterranean populations of the common Actinia equina another pigment is presumed to be present than in Atlantic ones. Crossland (1952) comments upon the possible occurrence of geographical variation of the colour in corals.

Chromosome studies could help, but since no one has been working in this field, we are in complete ignorance about the subject. In Japan, in the Laboratory of Chromosome Research (Hokkaido University, Sapporo) some work on coelenterates was carried out by $\mathrm{H}$. Niiyama (1943). He found two species of Hydra differing in the number of chromosomes, so in the group of the Hydrozoa chromosome counts apparently suffice in certain cases for the separation of species. Personal observations on Mediterranean corals made clear, however, that the technical problems for chromosome studies are considerable.

A study of the nematocysts does not seem to be a great help to coral taxonomy. Carlgren (1949) carried out a very thorough study on the nematocysts in the different anthozoan groups, mainly of Actiniaria. My own experience with ahermatypic as well as hermatypic corals showed a diversity of different nematocyst types within one polyp. Perhaps a statistical, comparative study can reveal some points of interest, even on specific level.

\section{B. Species.}

In general the system based on ecological criteria is not so different from that of the more recent authors.

Some important new points are:

- Favia amicorum includes Bikiniastrea laddi Wells, 1954, and Barabattoia mirabilis Yabe \& Sugiyama, 1941.

- Favia valenciennesi includes Favia eridani Umbgrove, 1940.

- Favia laxa includes Plesiastrea helianthoides Wells, 1940.

- Favites pentagona includes Aphrastrea deformis Lamarck, 1816.

- Favites pentagona, F. melicerum, and F.rufa nov. spec. are three sibling species. 
- Favites chinensis Verrill, 1866, is revived.

- Favites acuticollis includes Favites yamanarii Yabe \& Sugiyama, 1936.

- Favites abdita includes Astraea halicora Ehrenberg, 1834.

- Favites virens includes Favites ellisiana Verrill, 1901 (= Madrepora favosa auct.)

- Favites abdita, F. virens, and F. flexuosa are three sibling species.

- Goniastrea spectabilis includes Goniastrea mantonae Crossland, 1952.

- Goniastrea favulus Dana, 1846, is revived, and expanded to include Goniastrea aspera Verrill, 1865.

- Goniastrea australensis H. Milne Edwards \& Haime, 1857, is revived; it includes Goniastrea benhami Vaughan, 1917.

- Platygyra daedalea includes Astroria astreiformis H. Milne Edwards \& Haime, 1849.

- Leptoria phrygia includes Leptoria gracilis Dana, 1846.

- Hydnophora exesa includes Hydnophora grandis Gardiner, 1904.

- Hydnophora rigida probably includes Hydnophora mayori Hoffmeister, 1925.

- Caulastrea curvata is a new species.

For the 34 species, 147 identifiable names were available, of 108 of which the type specimens have been examined. Of the 39 remaining ones photographs or a very complete description enabled their identification. Of the latter group 13 ought have been in the MNHN; 7 (Ehrenberg, Klunzinger, and Brüggemann) in the ZMB. Two types were missing in Gl, of which one was already absent in 1914. The types in TIU can normally be consulted, but were not available temporarily. UP did not send types. Some of the types of Ortmann, Gardiner, Quelch, and Duncan could not be traced. There remains a list of 36 names, that because of various reasons cannot be placed precisely. Among them there are some good species of Faviinae, not present in the New Caledonia collection. A full revision of the Faviinae was not the author's aim, since it can only be based on fully labelled material. Some good Pacific Faviinae species are:

- Madrepora rotulosa Ellis \& Solander, 1786; holotype Gl; in my opinion a species of Favia, and a senior synonym of Favia hululensis Gardiner, 1904; holotype BMNH No. 1927.5.12.1 (see under $F$. pallida).
- Favia complanata Ehrenberg, 1834: 93; holotype ZMB No. 695; in my opinion belonging to Favites, synonymous with Astraea tessifera Ehrenberg, 1834: 97; holotype ? MNHN (see under $F$. virens).

- Coeloria crosslandi Matthai, 1928; holotype BMNH No. 28.3.1.7; in my opinion a Platygyra species.

- Coeloria klunzingeri Matthai, 1928; holotype BMNH No. 28.3.1.14; in my opinion a Platygyra species (see under $\boldsymbol{P}$. daedalea).

- Caulastrea tumida Matthai, 1928; holotype BMNH No. 28.6.2.1; in my upinion a valid species of Caulastrea (see under C. echinulata).

Coeloria gigantea Yabe \& Sugiyama, 1936, Coelogyra levis Nemenzo, 1959, and Caulastrea simplex Crossland, 1952, have already been mentioned, the first two as doubtful synonyms, the last one as a doubtful species. Most of the remaining species proved to belong to other coral groups, especially Montastreinae, or are West Indian species. Of many species the types were lost, destroyed or unidentifiable, and mostly they have never been cited in literature afterwards.

In many instances, the faunistics of New Caledonia correspond with those of the Great Barrier Reef (cf. Crossland, 1952); for example Favia favus and Favia speciosa are common, Favia pallid $a$ and Favia stelligera are rare. It may be assumed, in accordance with Wells, 1954, that the Indonesian Archipelago is the area richest in coral species; the data on the number of genera presently known suggest that New Caledonia with its great variation in habitats is part of this optimum area. Many species range widely over the IndoPacific region: Favia favus, Favia speciosa, Favia pallida, Favia stelligera, Favites pentagona, Favites abdita, Favites virens, Goniastrea retiformis, Goniastrea pectinata, Platygyra lamellina, Platygyra daedalea, Platygyra sinensis, Hydnophora exesa, Hydnophora microconos. Others are known from a small area only, in most cases due to insufficient collecting, but in other cases reflecting localized occurrence. For instance, Goniastrea australensis only from areas around the tropic of Capricorn and the tropic of Cancer, which may at least indicate that it is more abundant in cooler waters. Now that new light has been thrown on the number of species, physiological and ecological studies, e.g. on differences in the preferred food, could possibly be conceived in an aquarium. 


\section{Genera.}

Several species within the Faviinae are apparently related, and some of these groups can be considered to form a genus. Among the plocoid species, Favia speciosa, $F$. pallida and $F$. matthai form a typical group, closely allied to Favia favus, that has slightly larger corallites. Very eccentric is the species valenciennesi that may constitute a subgenus of its own, for which the name Phymastrea H. Milne Edwards \& Haime is available. Related seems $F$.amicorum, showing a more phaceloid form tending into the direction of the subdendroid genus Caulastrea. Another peripheral group is formed by $F$. stelligera and $F$.laxa, which often show extratentacular budding; especially in the latter character this group resembles the genus Plesiastrea (subfamily Montastreinae). The West Indian $F$. fragum (Esper, 1795), type of the genus Favia, stands rather peripheral in Favia and fits best near $F$. rotumana, both species coming close to the cerioid genus Favites.

Rather peripheral in Favites is $F$. palauensis which often shows a plocoid growth form. The same habit is found in $F$.chinensis, although this species is not allied to the former.

Among the cerioid species, Favites abdita, type of the genus, forms a complex of sibling species with $F$. virens and $F$. flexuosa. A related group of sibling species in Favites is $F$. pentagona, $F$. melicerum, and $F$. rufa.

$F$. acuticollis often has short meanders and thinner thecae, therefore resembling the genus Goniastrea.

In the submeandroid genus Goniastrea, G. retiformis (the type of the genus) and G. spectabilis are usually monocentric, resembling a cerioid growth form, although the thecae are thin and the paliform structure is clear. G. favulus tends to form short meanders, while the two closely related species G. pectinata and G. australensis, in particular the latter, can form rather long valleys. In this respect these two meandroid species of Goniastrea come close to the genus Platygyra, but in the latter genus pali are absent. $P$. lamellina (the type of the genus) and $P$.daedalea are closely allied species. $P$. sinensis has narrower valleys. Another meandroid genus is Oulophyllia, having very wide valleys; the only species discussed is O.crispa. On the other hand, the meandroid genus Leptoria has very narrow meanders; the only species discussed above is $L$. phrygia.

The hydnophoroid genus Hydnophora can be regarded as an extreme of the meandroid growth form.

It is clear that in corals, as in most other groups of animals, the limits between the genera are mainly artificial. The limit between Favia and Favites is obscure since some species of Favites may sometimes assume a plocoid growth form $(F$. chinensis; $F$. palauensis) and some species of Favia assume occasionally a cerioid growth form (F. rotumana). The same holds true for the separation between Favites and Goniastrea: $F$.acuticollis assuming a submeandroid growth form and G. spectabilis assuming a cerioid growth form. The boundary between Goniastrea and Platygyra is not sharp either, G. australensis having a meandroid growth form. The rest of the genera, in which no subgroups can be distinguished, have only a few species.

Although Hydnophora and Caulastrea are the only genera that can be sharply defined, the present delimitation of the genera is adhered to because all the species can be allocated with some confidence to a genus and because the system is a practical one. The use of still more generic names or the creation of new subgenera to contain groups of sibling species cannot be but confusing.

The distinction between the group of genera, forming the Faviinae, and the other subfamily, the Montastreinae, is very probably an artificial one, since it is based on a single character, the presence of intratentacular or extratentacular budding; the same opinion is expressed by Wells (1956). It could very well be that some of the Faviinae are closely related to some of the species in the Montastreinae. Some species of Favia show indeed sometimes extratentacular budding, e.g. $F$. matthai and $F$. laxa. For the purpose of the present study the current concept of the Faviinae was maintained and even narrowed by the elimination of Plesiastrea. Of the recent genera occurring in the IndoPacific as mentioned by Wells, the genera Bikiniastrea and Barabattoia have been eliminated through inclusion of their (synonymous) type species in Favia. The monotypical genus Montigyra Matthai, 1928, was not collected in New Caledonia, but from the description and photograph (Matthai, 1928, pl. 41 fig. 4) the impression is formed that it comes closest to Oulophyllia, but it can also be an extreme growth form of some other species. Because only one colony is known, it is best to leave this species out of discussion till more specimens are collected.

The rules for the variability in the species of the Faviinae, for the greater part explained as a rela- 
tion between skeleton deposit and environmental conditions, should be tested on other scleractinian taxa, at least on the Montastreinae. In other families of corals where the corallites are much smaller and the characters therefore less easy to

\section{SUMMARY}

A large collection of New Caledonian corals belonging to the subfamily Faviinae (Scleractinia) has been studied. The collection was made in different habitats, for which purpose the richly differentiated New Caledonian reef area was divided into seven main biotopes. The environmental factors influencing growth in each of these are described; for some abundant species regularities could be found correlating the morphological modifications and the different types of habitat. Through application of these "rules" to the whole subfamily, it was possible to lump populations that up to now were considered separate species, as ecotypes of one species.

Although the artificial nature of the delimitation of the subfamily Faviinae against the Montastreinae sensu Wells (1956) is stressed, the genus Plesiastrea H. Milne Edwards \& Haime, 1848, is referred to the latter subfamily and excluded from the Faviinae. The genera Bikiniastrea Wells, 1954, and Barabattoia Yabe \& Sugiyama, 1941, are incorporated into Favia Oken, 1815.

Thirty-four species were collected, two of them new to science; some other species are briefly discussed. To find the legitimate names it was necessary to inspect the types of the available taxa in the Faviinae; about $75 \%$ of these have been traced. Within some genera, groups of more closely related species are distinguished, but a division into subgenera is not advocated, since the taxonomy of this group of animals is still on a basic level. It was not the author's aim to monograph the Faviinae, since the old regional collections have to be supplemented with new material provided with ecological data as well, before the specific criteria developed in this paper can be applied. However, it is likely that most of the recent Indo-Pacific Faviinae are mentioned. find, it will be still more difficult to perceive a coral's specific diagram in spite of the chaotic variability, but still the new systematic principles brought forward in the present study may lead to a more natural classification of the corals.

\section{SAMENVATTING}

In dit proefschrift worden de resultaten besproken van de systematische bewerking van een grote collectie Pacifische koralen, behorende tot de subfamilie Faviinae (Scleractinia). Deze collectie werd in 1968 gedurende een verblijf van zes maanden op het Pacifische eiland Nieuw Caledonië door de auteur verzameld. Nauwkeurige aandacht kon geschonken worden aan de standplaats-factoren van de individuele kolonies. Het rif van Nieuw Caledonië werd voor dit doel in zeven arbitraire biotopen ingedeeld. De verschillende oecologische factoren, die de groei van de koraalkolonie beïnvloeden zijn beschreven; voor enkele algemene soorten die goed vertegenwoordigd zijn konden algemene regels opgesteld worden, die de verschillen in groei op de standplaatsen verklaarden.

Koralen van diepere groeiplaatsen hebben in het algemeen minder skeletafzetting. Relatief is de skeletproductie groter op het barrière rif dan op het kustrif. Door deze regels op de gehele subfamilie toe te passen, was het mogelijk verbanden te leggen tussen populaties, die als aparte soorten waren beschreven. Verscheidene van hen bleken ecotypen te zijn van éen soort.

De genera Bikiniastrea Wells, 1954, en Barabattoia Yabe \& Sugiyama, 1941, worden als synoniemen van het genus Favia Oken, 1815, beschouwd. Hoewel de kunstmatigheid van de grens tussen de subfamilies Faviinae en Montastreinae wordt erkend, is deze om practische redenen aangehouden. Daarbij is het genus Plesiastrea H. Milne Edwards \& Haime, 1848, niet meer tot de Faviinae gerekend.

Vierendertig soorten werden verzameld en beschreven, waaronder twee welke nog niet eerder bekend waren. Nog enkele andere Pacifische Faviinae taxa worden als soort opgevat en zijn besproken bij de discussie. Om de wettige namen te vinden was het noodzakelijk de typen behorende bij alle bestaande soortsnamen van de Faviinae te bestuderen; van ongeveer $75 \%$ is dit gelukt.

Binnen enkele genera kunnen groepen van nauwverwante soorten onderscheiden worden; soms is zelfs de term "sibling species" gebruikt. Omdat de taxonomie van deze diergroep nog in een pril stadium verkeert, is het prematuur geacht om subgenera te beschrijven.

Het lag niet in de bedoeling van de auteur om een monografie van de Faviinae te geven, daar er eerst meer materiaal ter beschikking moet komen waarvan de volledige standplaats-gegevens het toelaten om de in dit artikel ontwikkelde soortscriteria toe te passen. Het wordt echter waarschijnlijk geacht, dat de meeste soorten van de recente Indo-Pacifische Faviinae behandeld zijn. 


\section{LITERATURE}

Alloiteau, J., 1952. Madréporaires post-paléozoïques. In: J. Piveteau, Traité de paléontologie, 1. Protistes, Spongiaires, Coelentérés, Bryozoaires (II. Madréporaires): 539-570 (Masson, Paris).

BEDOT, M., 1907. Madréporaires d'Amboine. Rev. suisse Zool., 15 : 143-292, pls. 1-50.

Bernard, H. M., 1903. The genus Goniopora. Cat. madrep. corals Brit. Mus., 4: $1-206$, pls. 1-14 (Trustees Brit. Mus., London).

Best, MaYA B., 1968. Notes on three common species of madreporarian corals known as: Caryophyllia smithi, Caryophyllia clavus, Coenocyathus dohrni. Bijdr. Dierkunde, 38 : 17-22, pls. 1-7.

-, 1969. Etude systématique et écologique des Madréporaires de la région de Banyuls-sur-Mer (PyrénéesOrientales). Vie Milieu, (Biol.mar.) 20 (2) A : 293326, figs. $1-18$.

Blainville, H. M. D. De, 1830. Les Madrépores. Dictionnaire des Sciences naturelles, $60: 297-364$. (Levrault, Strasbourg).

Boschma, H., 1924. On two different growth-forms of Merulina laxa Dana. Zool. Meded. Rijksmus. nat. Hist., Leiden, 8 : 36-38, pl. 1.

- , 1948. The species problem in Millepora. Zool. Vesh., 1 : 115 , pls. $1-15$.

BrüggemanN, F., 1878. Neue Korallen-Arten aus dem Rothen Meer und von Mauritius. Abh. naturwiss. Ver. Bremen, $5: 395-400$, pls. 7-8.

-, 1879. Corals. In: Zoology of Rodriguez. Phil. Trans. R. Soc. London, 168 : 569-579.

Carlgren, C., 1949. A survey of the Ptychodactiaria, Corallimorpharia and Actiniaria. K. Svensk. Vetensk. Akad. Handl., (4) 1 : 1-121, pls. 1-4.

Crossland, C., 1931. The reduced building power and other variation in the astrean corals of Tahiti, with a note on Herpetolitha limax and Fungia spp. Proc. zool. Soc. London, 1931 : $351-392,13$ text-figs., pls. $1-22$.

- , 1941. On Forskal's collection of corals in the Zoological Museum of Copenhagen. Skr. Univ. Zool. Mus. Kjøbenhavn, 1 : $1-63$, pls. 1-12.

-, 1952. Madreporaria, Hydrocorallineae, Heliopora : Sci. Repts. Great Barrier Reef Exped., 1928-29, 6 : $85-257$, pls. $1-56$.

Czygan, F. C. \&. H. Seefried, 1970. Unterschiede in der Zusammensetzung der Carotinoide von Actinia equina (L.) aus der Nordsee und aus der Adria. Z. Naturforsch., 25b : 761-762.

DANA, J. D., 1846. Zoophytes. United States Exploring Expedition during the years $1838,1839,1840,1841$, 1842 under the command of Charles Wilkes, U.S.N., 7 : $1-740$, folio atlas of 61 pls. (Lea \& Blanchard, Philadelphia).

-, 1872. Corals and coral islands, 1st ed.: 1-378. (Sampson Low, London).

Di SAlvo, L. H., 1969. Isolation of bacteria from the corallum of Porites lobata (Vaughan) and its possible significance. Am. Zoolog., 9: 735-740.

Duncan, P. M., 1883. On the madreporarian genus Phymastrea of Milne Edwards and Jules Haime, with a description of a new species. Proc. zool. Soc. London, 1883 : 406-412, text-figs. $1-2$.
-, 1884. A revision of the families and genera of the sclerodermic Zoantharia, Ed. and H., or Madreporaria (M. rugosa excepted). J. Linn. Soc. London, (Zool.) 18 : $1-204$.

-, 1889. On the Madreporaria of the Mergui Archipelago. J. Linn. Soc. London, (Zool.) $21: 1-25$, pl. 1 .

Edwards, H. Milne ${ }^{5}$ ) \& J. Haime, 1848. Note sur la classification de la deuxième tribue de la famille des Astréidés. C.R. Acad. Sci. Paris, 27 : 490-497.

- \& - , 1849. Recherches sur les polypiers. Monographie des Astréidés (1). Astréens. Ann. Sci. nat., (Zool.) (3) $11: 233-312$.

- \& -, 1850. Recherches sur les polypiers. Monographie des Astréidés (1) suite. Astréens agglomérés. Ann. Sci. nat., (Zool.) (3) $12: 95-197$.

- \& -, 1857. Histoire naturelle des coralliaires, 2 : 1-663. (Roret, Paris).

- \& -, 1860. Histoire naturelle des coralliaires, 3 : 1-560. (Roret, Paris).

EhrenberG, C. G., 1834. Die Corallenthiere des Rothen Meeres physiologisch untersucht und systematisch verzeichnet. Abh. K. Ak. Wiss., Berlin, 1834 : 1-156.

Ellis, J. \& D. Solander, 1786. The natural history of many curious and uncommon zoophytes, collected from various parts of the globe : $1-208$, pls. 1-62. (White \& Son, London).

EsPER, E. J. C., 1794-1797. Fortsetzungen der Pflanzenthiere in Abbildungen nach der Natur mit Farben erleuchtet nebst Beschreibungen, 1: 1-164 (1794), 65-116 (1795), 117-168 (1796), 169-230 (1797). (Raspeschen Buchh., Nürnberg).

Faustino, L. A., 1927. Recent Madreporaria of the Philippine Islands. Monogr. Bur. Sci. Manila, 22 : $1-310$, pls. $1-100$.

FoIdART, J., 1970. Rapport scientifique de l'expédition belge à la grande barrière d'Australie en 1967. Madrépores: I. Etude morphologique et systématique comparée de Goniastrea retiformis (Lam.) et Goniastrea parvistella (Dana). Ann. Soc. R. zool. Belg., 100 $(1-2)$ : 85-114, pls. $1-6$.

ForSKÅL, P.6), 1775. Descriptiones animalium, avium, amphibiorum, piscium, insectorum, vermium; quae in itinere orientale observavit : $1-164$, pls. 1-43. (Mölleriaulae Typographi, Hauniae).

GARDINER, J. S., 1899. On the astraeid corals collected by the author in the South Pacific. Proc. zool. Soc. London, 1899 : 734-764, pls. 46-49.

- , 1904. Madreporaria. I. Introduction with notes on variation. II. Astraeidae. Fauna Geogr. Maldive Laccadive Archipelagoes, 2 : 755-790, pls. 59-64. (Univ. press, Cambridge).

5) According to the Index biographique des membres et correspondants de l'Académie des Sciences depuis 1795 (see annuaire de l'Académie des Sciences) this name should be classified under the letter $E$.

•) According to Dr. T. Wolf, 1968: 585 (Bull. Inst. océanogr. Monaco, No. spécial 2), the correct spelling is Forsskål. The arguments are convincing, but Forskål is the spelling used throughout the literature. 
GoreaU, T. F., 1959. The physiology of skeleton formation in corals under different conditions. Biol. Bull., 116 : $59-75$.

-, 1963. Calcium carbonate deposition by coralline algae and corals in relation to their role as reefbuilders. Ann. New York Ac. Sc., 109 : 127-167.

Gorenu, T. F. \& N. I. Goreau, 1959. The physiology of skeleton formation in corals. II. Calcium deposition by hermatypic corals under various conditions in the reef. Biol. Bull., 117 : 239-250.

Hoffmeister, J. E., 1925. Some corals from American Samoa and the Fiji Islands. Paper Dept. mar. Biol. Carnegie Inst. Washington, 22 : 1-90, pls. 1-23.

Klunzinger, C. B., 1879. Die Korallenthiere des Rothen Meeres, 3. Die Steinkorallen, Zweiter Abschnitt (Schluss). Die Astraeaceen und Fungiaceen : 1-100, pls. 1-10 (Gutmann, Berlin).

Lamarck, J. B. P. DE, 1801. Polypes à rayons. Système des animaux sans vertèbres : 360-386 (Lanou, Paris).

-, 1816. Polypiers lamellifères. Histoire naturelle des animaux sans vertèbres, 2 : 209-287 (Lanou, Paris).

LINK, H. T., 1807. Beschreibung der Naturalien-Sammlung der Universität zu Rostock, 3 : 161-165 (in part).

Matthai, G., 1914. A revision of the recent colonial Astraeidae possessing distinct corallites. Trans. Linn. Soc. London, (Zool.) (2) $17: 1-140$, pls. $1-38$.

-, 1923. Madréporaires de Nouvelle Calédonie. Bull. biol. France Belg., 57 : 70-88, pls. 1-2.

-, 1924. Report on the madreporarian corals in the collection of the Indian Museum, Calcutta. Mem. Indian Mus., $8: 1-59$, pls. $1-11$.

- , 1928. A monograph of the recent meandroid Astreidae. Cat. madreporarian corals, $7: 1-288$, pls. $1-72$ (Trustees Brit. Mus., London).

MAYER, A. G., 1918. Ecology of the Murray Island Coral Reef. Pap. Dept. mar. Biol. Carnegie Inst. Washington, 9 : 1-48, pls. 1-19.

Milne Edwards, H., see Edwards, H. Milne.

Nemenzo, F., 1955. On the scleractinian fauna of Puerto Galera Bay, Oriental Mindoro, and Laguimanoe Bay, Quezon. Bull. nat. appl. Sci., 15 : 131-138, pls. 1-2.

,- 1959 . Systematic studies on Philippine shallow water scleractinians, 2. Suborder Faviida. Bull. nat. appl. Sci., 16 : 73-135, pls. 1-24.

NiIYAMA, H., 1943. A study of chromosomes in Hydra. Cytologia, 13 : $204-209$.

OKen, L., 1815. 1. Zunft. Erdkorallen, Steinkorallen. Lehrbuch der Naturgeschichte, Dritter Theil, Zoologie, Erste Abteilung, Fleischlose Thiere: 59-74 (Schmid, Leipzig, Jena).

OrTmanN, A., 1889. Beobachtungen an Steinkorallen von der Südküste Ceylons. Zool. Jahrb., (Syst.) 4 : 493590, pls. $11-18$.

Pallas, P. S., 1766. Elenchus zoophytorum : 1-451 (P. van Cleef, Hagae comitum).

QUELCH, J. J., 1886. Report on the reef-corals. Sci. Rep. Challenger Exped., (Zool.) $16: 1-203$, pls. 1-12.

QuoY, J. R. C. \& J. P. Gaimard, 1833. Zoophytes. Voyage Astrolabe, (Zool.) 4: 1-39 + Atlas (26 pls) (Tastu, Paris).

Rehberg, H., 1892. Neue und wenig bekannte Korallen. Abh. naturwiss. Ver. Hamburg, $12: 1-50$, pls. $1-4$.

Roos, P. J., 1967. Growth and occurrence of the reef coral Porites astreoides Lamarck in relation to sub- marine radiance distribution : 1-72. (Thesis, Univ. Amsterdam) (Elinkwijk, Utrecht).

Rosen, B. R., 1968. An account of a pathologic structure in the Faviidae (Anthozoa): a revision of Favia valenciennesi (Edwards \& Haime) and its allies. Bull. Brit. Mus. (nat. Hist.), (Zool.) 16 (8) : $325-352$, pls. $1-8$

RousseaU, L., 1854. Zoophytes. In: Voyage au pôle Sud de Dumont d'Urville, (Zool.) 5 : 119-124, pls. 27-29 in Atlas (Gide, Paris).

STODDART, D. R., 1969. Ecology and morphology of recent coral reefs. Biol. Rev., $44: 433-498$.

ThIEL, M. E., 1932. Madreporaria zugleich ein Versuch einer Vergleichenden Oekologie der gefundenen Formen. Mem. Mus. Hist. nat. Belg., (hors. Sér.) 2 (12) : $1-177$, pls. $1-21$.

Umbgrove, J. H. F., 1928. De Koraalriffen in de Baai van Batavia. Wetensch. Meded. Dienst Mijnbouw Bandoeng Java, 7 : $1-68$, pls. 1-33.

-, 1939. Madreporaria from the Bay of Batavia. Zool. Meded. Leiden, $22: 1-64,4$ text-figs. pls. $1-18$.

-, 1940. Madreporaria from the Togian reefs (Gulf of Tomini, North-Celebes). Zool. Meded. Leiden, 22 : 265-310, 3 text-figs., pls. 21-35.

Vaughan, T. W., 1901. Some fossil corals from the elevated reefs of Curaçoo, Aruba and Bonaire. Samml. geolog. Reichs Mus. Leiden, (2) 2 (1) : $1-91$.

- , 1907. Recent Madreporaria of the Hawaiian Islands and Laysan. Bull. U.S. nation. Mus., 59 : $1-427$, fig. 1, pls. $1-96$.

-, 1917. Some corals from Kermadec Islands. Trans. New Zealand Inst., $49: 275-279$, pls. 17-20.

-, 1918. Some shoal-water corals from Murray Island, Cocos-Keeling Islands, and Fanning Island. Pap. Dept. mar. Biol. Carnegie Inst. Washington, 9 : 49-234, 2 text-figs., pls. 20-93.

Vaughan, T. W. \& J. W. Wells, 1943. Revision of the suborders, families, and genera of the Scleractinia. Geol. Soc. America spec. Pap., 44: 1-363, figs. $1-39$, tables $1-3$, pls. $1-51$.

Verrill, A. E., 1866. Corals and polyps of the North Pacific Exploring Expedition, with descriptions of other Pacific Ocean species. Proc. Essex Inst., 5 : 17-32, pls. $1-2$.

,- 1867 . Corals and polyps of the North Pacific Exploring Expedition, with descriptions of other Pacific Ocean species. Proc. Essex Inst, 5 : 33-50.

- 1872. Names of species of corals. In: J. D. DANA, Corals and coral islands, 1st ed.: 379-388. (Sampson Low, London).

,- 1901 . Variations and nomenclature of Bermudian, West Indian, and Brazilian reef corals, with notes on various Indo-Pacific corals. Trans. Conn. Acad. Arts Sci., 11 : $63-168$, pls. $1-26$.

VERWEY, J., 1931. Coral reef studies, 2. The depth of coral reefs in relation to their oxygen consumption and the penetration of light in the water. Treubia, 13 (2) : $169-198,2$ text-figs.

Weber, J. N. \& P. M. J. WoOdhead, 1969. Factors affecting the carbon and ogygen isotopic composition of marine carbonate sediments, 2. Heron Island, Great Barrier Reef, Australia. Geoch. Cosmoch. Acta, 33 : 19-38.

$-\&-, 1970$. Carbon and oxygen isotope fractionation 
in the skeleton carbonate of reef-building corals. Chem. Geol., $6: 93-117$.

Wells, J. W., 1936. The nomenclature and type species of some genera of recent and fossil corals. Amer. J. Sci., (5) 31 : 97-134.

-, 1954. Recent corals of the Marshall Islands. U.S. geol. Survey, prof. Pap., 260-1 : 385-486, pls. 94185.

- , 1955. A survey of the distribution of reef coral genera in the Great Barrier Reef region. Rep. Gt. Barrier Reef Comm., 6 (2) : 1-9.

- , 1956. Scleractinia. In: R. C. Moore (ed.), Treatise on Invertebrate Paleontology : (F) Coelenterata : 328444, text-figs. 222-339. (Lawrence, Kansas).

-, 1957 a. Coral Reefs. Mem. geol. Soc. America, 67 (1) : 609-631, figs. $1-2$, pls. $1-9$.

-, 1957 b. Corals. Mem. geol. Soc. America, 67 (1) : 1087-1104, fig. 1 .
Wussman-Best, Maya, 1970. A new species of Polycyathus Duncan, 1876 from New Caledonia and a new record of Polycyathus senegalensis Chevalier, 1966 (Madreporaria). Beaufortia, 17 (227) : 79-84, figs. $1-4$.

Yabe, H. \& T. SugiYama, 1941. Recent reef buildings corals from Japan and the South Sea islands under the Japanese mandate. II. Sci. Repts. Tohoku Imp. Univ., (2) spec. $2: 67-91$, pls. $60-104$.

Yabe, H., T. SugiYama \& M. Eguchi, 1936. Recent reef building corals from Japan and the South Sea islands under the Japanese mandate. I. Sci. Repts. Tohoku Imp. Univ., (2) spec. 1 : $1-66$, pls. 1-59.

YongE, C. M., 1940. The biology of reef-building corals. Sci. Repts. Gt. Barrier Reef Exped., 1928-1929, 1 : 353-361.

-, 1968. Review lecture, living corals. Proc. roy. Soc., (B) $169: 329-344$.

Received: 18 July 1971. 


\section{INDEX}

The page of main treatment of a taxon is printed in bold.

abdita, Favites

abdita, Madrepora

acropora, Favia

acuticollis, Favites

acuticollis, Prionastrea

adduensis, Favia

affinis, Parastrea

aiharai, Caulastrea

amicorum, Favia

amicorum, Parastrea

amplior, Parastrea

ananas, Astrea

applanata, Hydnophora tenella var.

arabica, Coeloria

armata, Plesiastrea

aspera, ecotype

aspera, Favites

aspera, Goniastrea

aspera, Oulophyllia

aspera, Parastrea

aspera, Phymastrea

astreiformis, Astroria

astreiformis, ecotype

astreiformis, Platygyra

astrinus, Favites

astroides, Porites

australensis, Goniastrea

australensis, Prionastrea

benhami, ecotype

benhami, Goniastrea

bertholleti, Favia

bertholleti, Parastrea

borradailei, Orbicella

bottai, Coeloria

bournoni, Goniastrea

catalai, Alveopora

cavernosa, ecotype

cavernosa, Madrepora

cellulosa, Astraea

cellulosa, Oulophyllia

cerium, Astraea

chinensis, Favites

chinensis, Prionastrea

clouei, Favia

complanata, Favia

complanata, Favites

contignatio, Hydnophora

contignatio, Madrepora

cooperi, Coeloria

coronalis, Goniastrea

crassidens, ecotype

crassidens, Favia favus var.

crassior, Prionastrea

crater, Turbinaria

crispa, Meandrina

crispa, Oulophyllia

crosslandi, Coeloria

curvata, Caulastrea

cynarea, Cynarina $\begin{array}{lllllllll}12 & 26 & 31 & 33 & 34 & 35 & 36 & 37 & 60\end{array}$

$\begin{array}{llllll}61 & 62 & 64 & 65 & 66 & 67\end{array}$

2633

2425

$\begin{array}{lllllll}12 & 26 & 32 & 33 & 60 & 66 & 67\end{array}$

3032

2728

1315

5455

$\begin{array}{llllllllll}12 & 13 & 21 & 22 & 23 & 60 & 61 & 62 & 65 & 67\end{array}$

2122

1819

2122

5152

46

2425

4161

41

293340416566

4950

1315

222324

464866

485761

64

26

58

$\begin{array}{llllllllllll}12 & 38 & 42 & 43 & 44 & 45 & 47 & 60 & 61 & 62 & 66 & 67\end{array}$

43

61

43444566

23

22

1315

45

38

63

60

1314

1819

49

4143

$\begin{array}{llllll}11 & 26 & 31 & 60 & 66 & 67\end{array}$

31

$\begin{array}{lll}16 & 1731\end{array}$

3666

31

52

51

49

4142

6062

1215

3334

6263

49

1249506167

66

1254566566

63 
daedalea, Coeloria

daedalea, Madrepora

daedalea, Platygyra

danae, Favia

deformis, Aphrastrea

deformis, Astraea

deformis, ecotype

demidovii, Hydnophora

denticulata, Astraea

denticulata, Favia

denticulata, Madrepora

distorta, Caulastrea

distorta, Fungia

doreyensis, ecotype

doreyensis, Favia

echinulata, Caulastrea

echinulata, Dasyphyllia

edwardsi, Coeloria

ehrenbergi, Favia

ehrenbergi, Hydnophora

ellisiana, ecotype

ellisiana, Favites

equina, Actinia

equisepta, ecotype

equisepta, Goniastrea

eridani, ecotype

eridani, Favia

esperi, Astroria

esperi, ecotype

exesa, Hydnophora

exesa, Madrepora

exigua, Platygyra

eximia, Astraea

fanningensis, ecotype

fanningensis, Favia stelligera var.

fascicularis, Galaxea

fastigiata, Eusmilia

favistella, Astraea

favosa, Favites

favosa, Madrepora

favulus, Astraea

favulus, Goniastrea

favus, Favia

favus, Madrepora

filicosa, Astraea

flexuosa, Astraea

flexuosa, Favites

folium, Monticularia

forskalana, Coeloria

fragilis, Astraea

fragum, Favia

fragum, Madrepora

furcata, Caulastraea

fusco-viridis, Astraea

fusco-viridis, ecotype

geoffroyi, Parastrea

geoffroyi, Trachyphyllia

gibbosa, Prionastrea

gibbosissima, ecotype

gibbosissima, Prionastrea

gigantea, Coeloria
48

46

$\begin{array}{llllllll}12 & 42 & 45 & 46 & 48 & 49 & 51 & 60\end{array}$

$\begin{array}{llllll}61 & 62 & 64 & 65 & 66 & 67\end{array}$

1315

2865

2728

2860

51

1819

15

1315

5556

62

60

1819

$12545556 \quad 66$

5455

4648

$\begin{array}{llll}12 & 15 & 28 & 29\end{array}$

5152

$36 \quad 6061$

$\begin{array}{lllll}35 & 36 & 60 & 65 & 66\end{array}$

65

61

4344

60

222360616465

4648

6162

$\begin{array}{lllllll}12 & 51 & 52 & 53 & 61 & 62 & 66\end{array}$

51

4041

38

60

2425

62

56

$41 \quad 43$

36

3566

40

$\begin{array}{lllllllll}12 & 33 & 37 & 40 & 41 & 61 & 65 & 66 & 67\end{array}$

$\begin{array}{llllllllllllllll}12 & 15 & 16 & 17 & 18 & 24 & 28 & 29 & 37 & 42 & 60 & 61 & 62 & 63 & 66 & 67\end{array}$ 13

3536

36

$\begin{array}{lllllll}12 & 27 & 36 & 37 & 61 & 66 & 67\end{array}$

5152

45

1617

67

12

12545556

3334

61

$13 \quad 15$

62

$33 \quad 34$

60

2728

4466 
goroensis, Barabattoia gracilis, ecotype gracilis, Leptoria gracilis, Meandrina gracilis, Platygyra grandis, ecotype grandis, Hydnophora grayi, Goniastrea gyrosa, ecotype gyrosa, Hydnophora

haeckeli, Plesiastrea halicora, Astraea halicora, ecotype halicora, Favites helianthoides, ecotype helianthoides, Favia helianthoides, Plesiastrea hemprichii, Acanthastrea hemprichii, Astraea heronensis, Tubastrea hombroni, Favia hombroni, Parastrea horrescens, Acrhelia hululensis, Favia hystrix, Hydnophora

incrustans, Goniastrea intersepta, Astraea irregularis, Favia, ecotype irregularis, Phymastrea

jacquinoti, Parastrea

klunzingeri, Coeloria

klunzingeri, Hydnophora

klunzingeri, Platygyra

laccadivica, Favia laddi, Bikiniastrea laddi, ecotype lamellina, Maeandra lamellina, Platygyra laticollis, Coeloria laticollis, Favia ehrenbergi var.

laxa, ecotype

Iaxa, Favia

laxa, Goniastrea

laxa, Orbicella

laxa, Merulina

leptoticha, Coeloria

leptoticha, ecotype

levis, Coelogyra

lobata, ecotype

lobata, Favia

lobata, Monticularia

lobata, Parastrea

magna, Coeloria

magnifica, Astraea

maginifica, Favastrea

magnistellata, Prionastrea

maldivensis, ecotype

maldivensis, Hydnophora

maldivensis, Stephanocoenia
2122

5061

505766

50

51

6162

50526566

4143

515262

515265

2728

333466

$\begin{array}{lllll}33 & 34 & 57 & 60\end{array}$

$\begin{array}{lllll}34 & 36 & 37 & 60 & 64\end{array}$

60

2665

2565

3457

33

62

25

24

6263

1966

63

3940

2425

60

2223

13

66

53

48

1819

21226065

216062

45

$124546486166 \quad 67$

45

33

60

$\begin{array}{lllllllll}12 & 13 & 25 & 26 & 60 & 61 & 65 & 67 & 68\end{array}$

29

25

62

4546

60

4566

60

25

5152

24

50

39

3334

3436

5361

515265

2728 
mantonae, ecotype

mantonae, Goniastrea

matthai, Favia

mayori, Hydnophora

meandrina, Monticularia

melicerum, Astraea

melicerum, Favites

melicerum, Prionastrea

merleti, Blastomussa

microconos, Hydnophora

microconos, Monticularia

microstoma, Favia ehrenbergi, var.

mirabilis, Barabattoia

multilobata, ecotype

multilobata, Goniastrea

obtusata, Prionastrea

okeni, Astraea

okeni, Favia

ordinata, Astraea

palauensis, Favia

palauensis, Favites

pallida, Astraea

pallida, Favia

pandanus, Astraea

pandanus, ecotype

papyracea, Leptoseris

parvicella, Favites

parvimurata, Favia

parvistella, Astraea

parvistella, ecotype

parvistella, Goniastrea

patella, Fungia

pectinata, Astraea

pectinata, Goniastrea

pentagona, Favia

pentagona, Favites

pentagona, Madrepora

phrygia, Leptoria

phrygia, Madrepora

phrygia, Platygyra

picteti, Euphyllia

planulata, ecotype

planulata, Goniastrea

polygonata, Monticularia

porcata, Astraea

profunda, ecotype

profunda, Favites yamanarii var.

profundicella, Prionastrea

profundior, Phymastrea

profundior, Prionastrea

puteolina, Astraea

puteolina, ecotype

quoyi, Goniastrea

quoyi, Prionastrea

ramosa, Hydnophora

retiformis, Astraea

retiformis, Goniastrea

rigida, Hydnophora

rigida, Merulina
61

394066

$\begin{array}{lllllll}12 & 13 & 19 & 20 & 61 & 65 & 67\end{array}$

535465

5152

29

$122628293041 \quad 60 \quad 6165 \quad 67$

28

63

1251536166

53

13

212265

61

4143

3334

17

1617

1819

31

$\begin{array}{llllll}12 & 2631 & 61 & 65 & 67\end{array}$

18

$\begin{array}{llllllll}12 & 18 & 19 & 20 & 26 & 57 & 60 & 61\end{array}$

$6466 \quad 67$

$16 \quad 17$

186062

62

2728

4041

38

3960

38

62

41

$\begin{array}{lllllllllll}12 & 38 & 41 & 42 & 43 & 44 & 47 & 60 & 61 & 66 & 67\end{array}$

29

$\begin{array}{llllllll}12 & 26 & 27 & 28 & 29 & 30 & 60 & 62\end{array}$

656667

2728

$\begin{array}{lllllll}12 & 50 & 51 & 57 & 61 & 66 & 67\end{array}$

50

51

63

4261

414243

5152

15

60

3233

33

2223

34

$16 \quad 17$

6062

404143

3334

5354

3738

$\begin{array}{llllllll}12 & 37 & 38 & 39 & 61 & 65 & 66 & 67\end{array}$

$\begin{array}{lllllll}12 & 51 & 53 & 54 & 61 & 62 & 66\end{array}$

53 
robusta, Astraea

robusta, ecotype

rotulosa, Favia

rotulosa, Madrepora

rotumana, Astraea

rotumana, Favia

rousseaui, Favia

rousseaui, Parastrea

rudis, Astraea

rudis, Goniastrea

rufa, Favites

rustica, Coeloria

rustica, Meandrina

ryukyensis, Platygyra

savignyi, Parastrea

serrata, Goniastrea

seychellensis, Prionastrea

simplex, Caulastrea

sinensis, Astroria

sinensis, Coeloria

sinensis, Platygyra

sinuosa, Astraea

solida, Goniastrea

speciosa, Astraea

speciosa, Favia

spectabilis, Goniastrea

spectabilis, Prionastrea

spinosa, Prionastrea

spongia, Astraea

stelligera, Astraea

stelligera, Favia

stricta, Astroria

stricta, Coeloria

stricta, Platygyra

subdentata, Coeloria

sulfurea, Prionastrea

superficialis, Prionastrea vasta var.

tenella, ecotype

tenella, Hydnophora

tenuidens, Goniopora

tenuis, Meandrina

tenuis, Platygyra

tessifera, Astraea

tessifera, Favia

tubulifera, Favia

tumida, Caulastrea

typica, Favites yamanarii var.

undulata, Caulastrea

urvilleana, Favia

urvilleana, Parastrea

valenciennesi, Favia

valenciennesi, Phymastrea

vasta, ecotype

vasta, Prionastrea

versipora, Plesiastrea

virens, Astraea

virens, Favites

yamanarii, ecotype

yamanarii, Favites
3334

$\begin{array}{llll}33 & 34 & 60 & 62\end{array}$

19

66

20

$\begin{array}{llllllll}12 & 13 & 20 & 21 & 61 & 64 & 66 & 67\end{array}$

15

13

$15 \quad 17$

2728

$\begin{array}{lllllll}12 & 26 & 30 & 31 & 61 & 65 & 67\end{array}$

4957

4648

48

1315

1819

333435

5666

48

49

$\begin{array}{llllll}12 & 45 & 48 & 49 & 66 & 67\end{array}$

4143

38

151617

$\begin{array}{lllllllll}12 & 16 & 17 & 60 & 61 & 62 & 64 & 66 & 67\end{array}$

$\begin{array}{lllllll}12 & 36 & 39 & 40 & 61 & 66 & 67\end{array}$

39

33

38

24

$\begin{array}{llllllll}12 & 13 & 24 & 25 & 60 & 61 & 66 & 67\end{array}$

48

49

49

45

3334

3536

5261

515265

57

50

51

66

36

13

$5556 \quad 66$

33

56

19

18

1213222324606162646567

22

36

3536

26

3536

$\begin{array}{llllllllllll}12 & 27 & 35 & 36 & 37 & 60 & 61 & 62 & 64 & 65 & 66 & 67\end{array}$

60

313366 

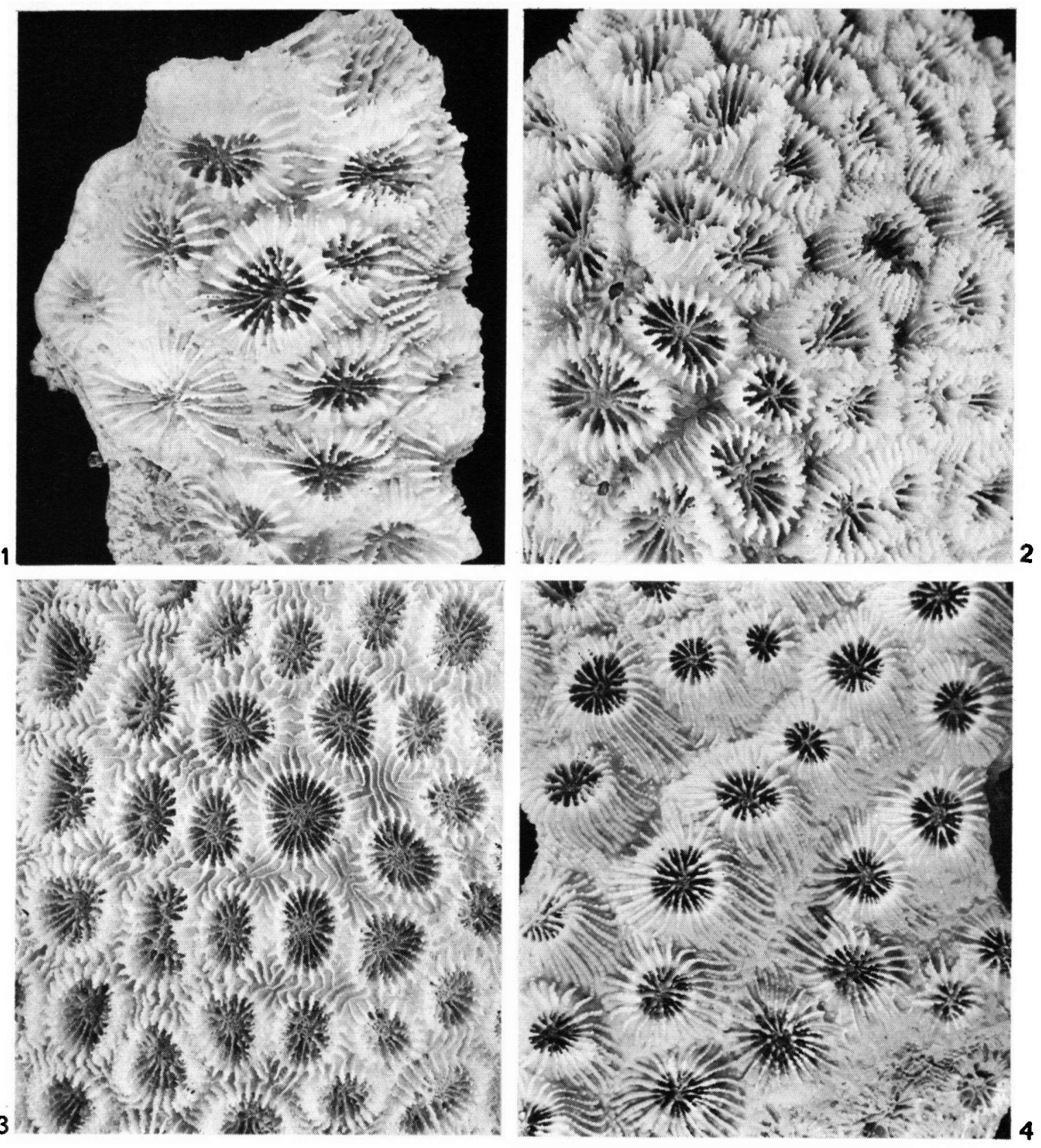

PI. I.

Fig. 1. Favia speciosa. Ecotype from biotope 1 (depth $30 \mathrm{~m}$ ); ZMA Coel. 5626, $1.7 \times$.

Fig. 3. Favia speciosa. Ecotype from biotope 6 (depth $10 \mathrm{~m}$ ); ZMA Coel. 5646, $1.7 \times$.

Fig. 2. Favia speciosa. Ecotype puteolina from biotope 3 (depth $5 \mathrm{~m}$ ); ZMA Coel. $5627,2.0 \times$.

Fig. 4. Favia speciosa. Ecotype from biotope 7 (depth $30 \mathrm{~m}$ ); ZMA Coel. 5662, $1.7 \times$. 

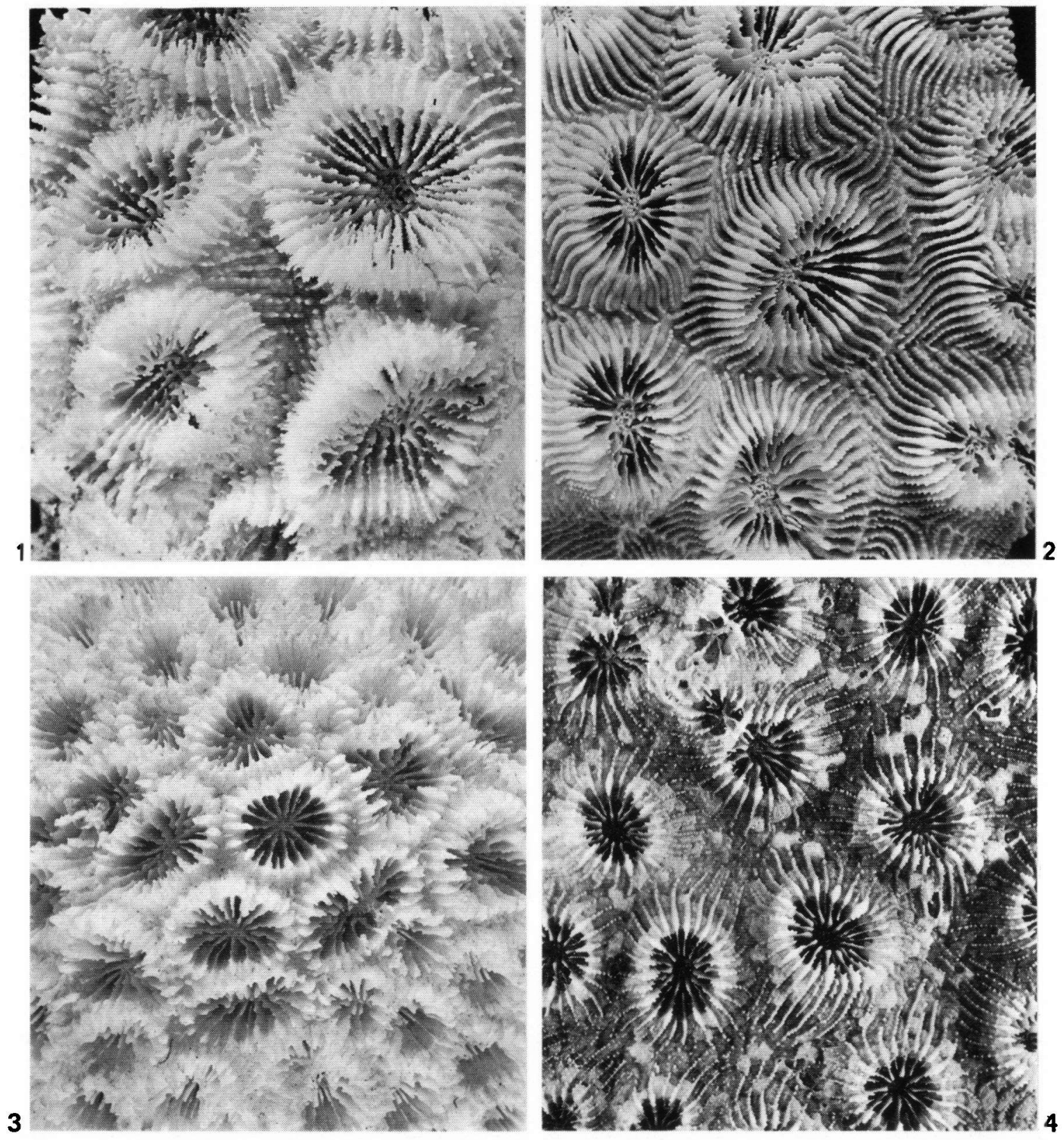

PI. II.

Fig. 1. Favia favus. Ecotype from biotope 1 (depth $30 \mathrm{~m}$ ); ZMA Coel. 5692, $2.0 \times$.

Fig. 3. Favia pallida. Ecotype from biotope 2 (depth $10 \mathrm{~m}) ;$ ZMA Coel. 5668, 1.7.
Fig. 2. Favia favus. Ecotype from biotope 7 (depth $35 \mathrm{~m}$ ); ZMA Coel. 5711, $1.7 \times$.

Fig. 4. Favia pallida. Ecotype from biotope 7 (depth $35 \mathrm{~m})$; ZMA Coel. 5672, $1.7 \times$. 

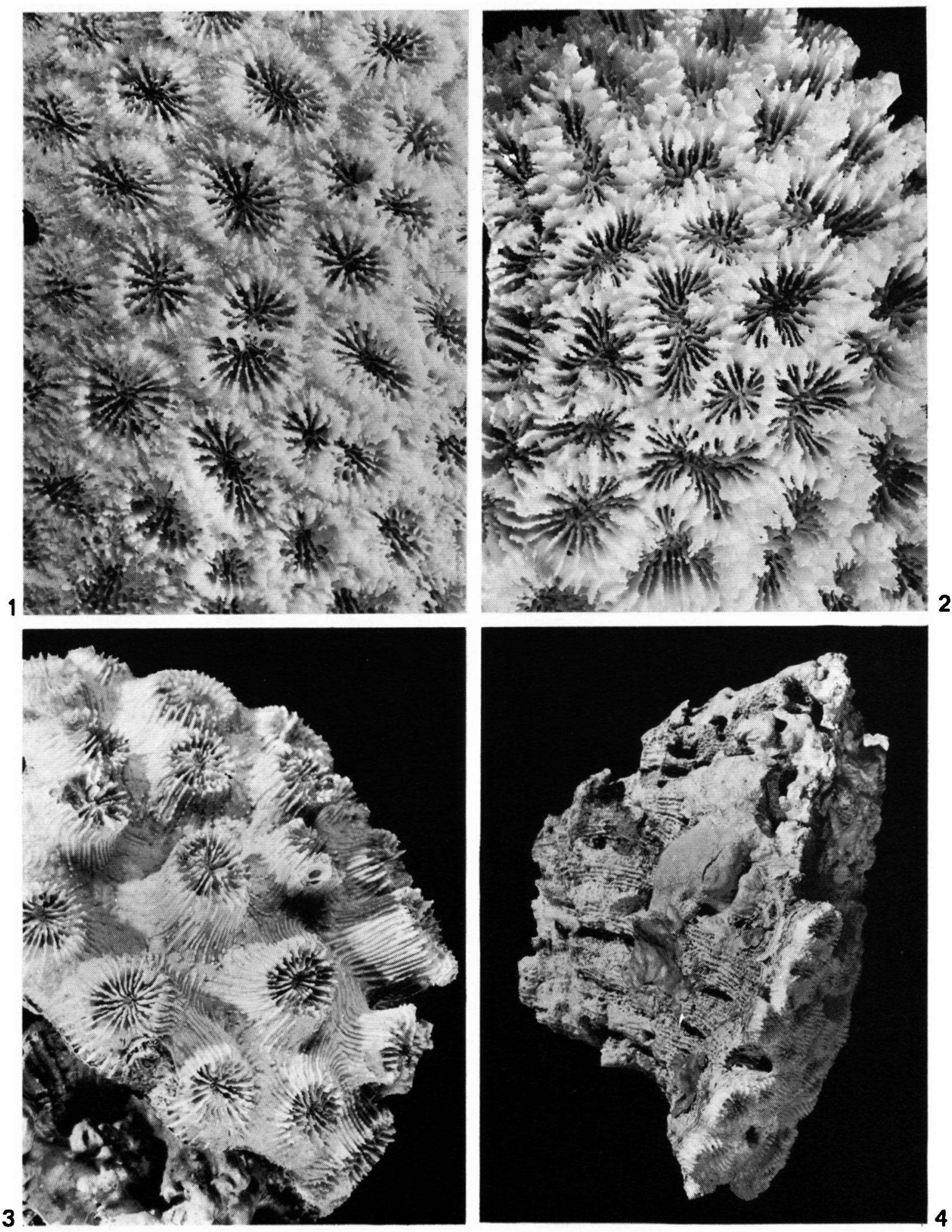

P1. III.

Fig. 1. Favia matthai. Ecotype from biotope 2 (depth $15 \mathrm{~m}$ ); ZMA Coel. 5682, $2.1 \times$.

Fig. 2. Favia rotumana. Ecotype from biotope 1 (depth $30 \mathrm{~m}$ ); ZMA Coel. 5686, $1.7 \times$.

Fig. 3. Favia amicorum. Ecotype laddi from biotope 7 (depth $30 \mathrm{~m}$ ); ZMA Coel. 5726, $1.5 \times$.

Fig. 4. Favia amicorum. Ecotype laddi from biotope 7 (depth $32 \mathrm{~m}$ ); ZMA Coel. 5728, $0.8 \times$. 

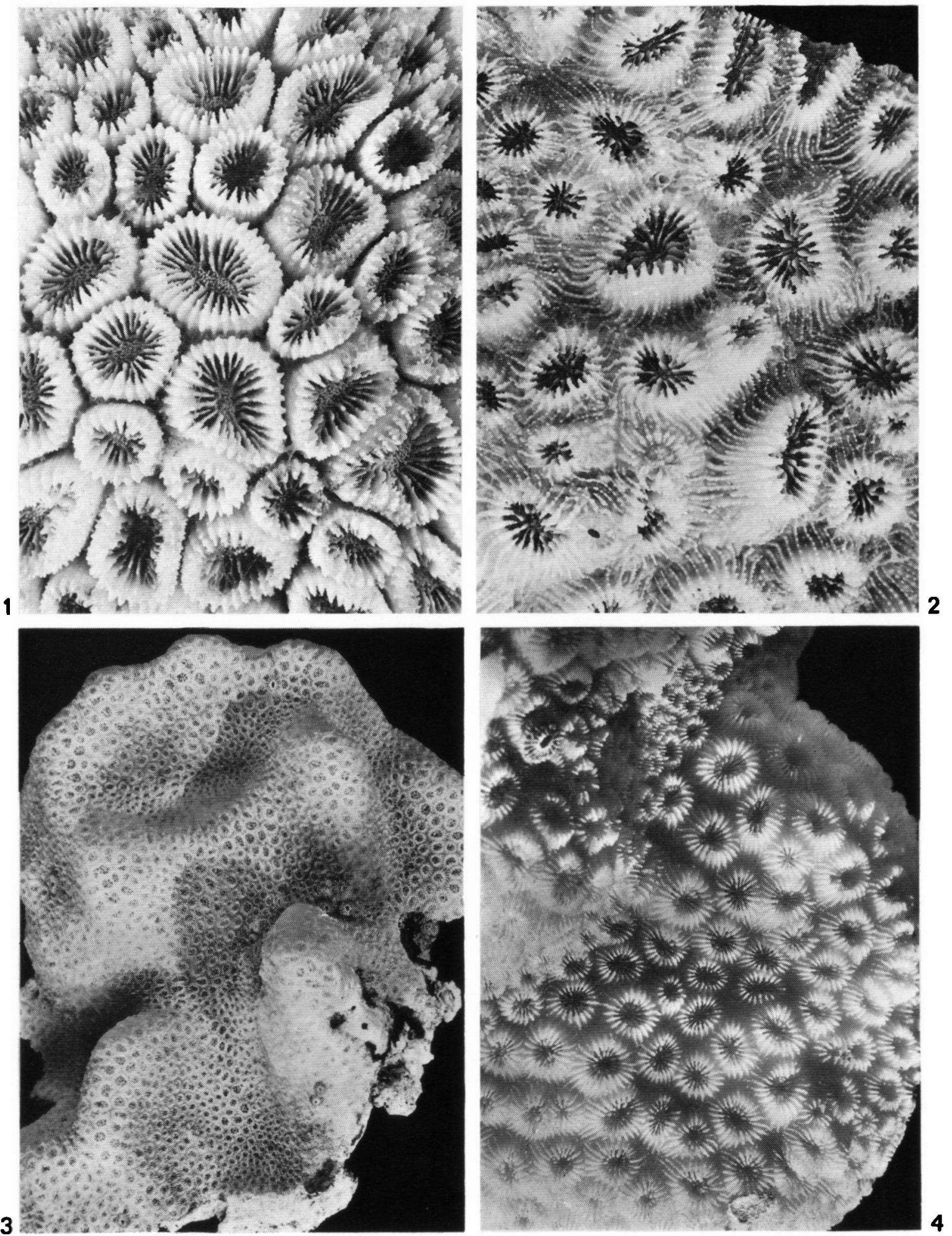

Pl. IV.

Fig. 1. Favia valenciennesi. Ecotype from biotope 4 (depth $8 \mathrm{~m}$ ); ZMA Coel. 5739, $1.7 \times$.

Fig. 3. Favia stelligera. Ecotype from biotope 2 (depth $15 \mathrm{~m})$; ZMA Coel. 5752, $0.6 \times$.

Fig. 2. Favia valenciennesi. Ecotype eridani from biotope 7 (depth $20 \mathrm{~m}$ ); ZMA Coel. 5751, $1.7 \times$.

Fig. 4. Favia laxa. Ecotype helianthoides from biotope 2 (depth $20 \mathrm{~m}$ ); ZMA Coel. 5797, $2.1 \times$. 

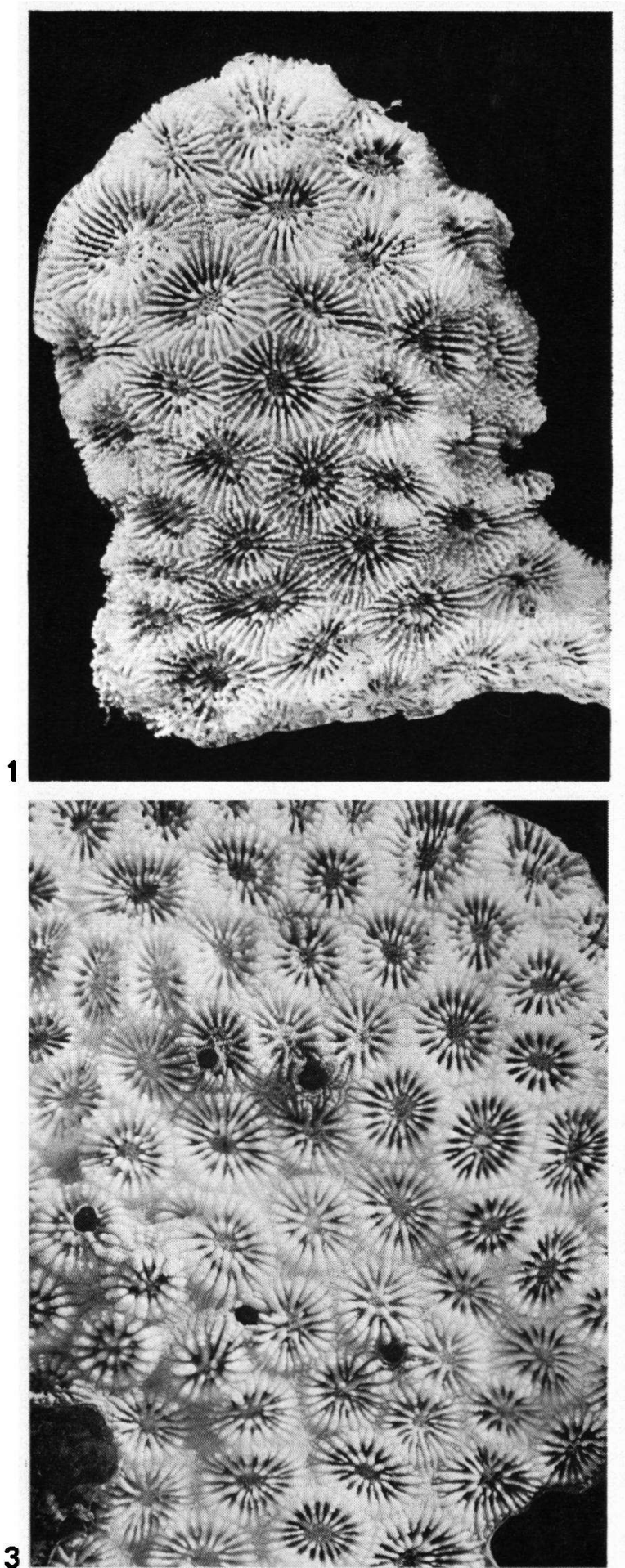

Pl. V.

Fig. 1. Favites pentagona. Ecotype from biotope 6 (depth $10 \mathrm{~m}$ ); ZMA Coel. 5831, $2.0 \times$.

Fig. 3. Favites melicerum. Ecotype from biotope 7 (depth $5 \mathrm{~m}$ ); ZMA Coel. 5820, $1.9 \times$.
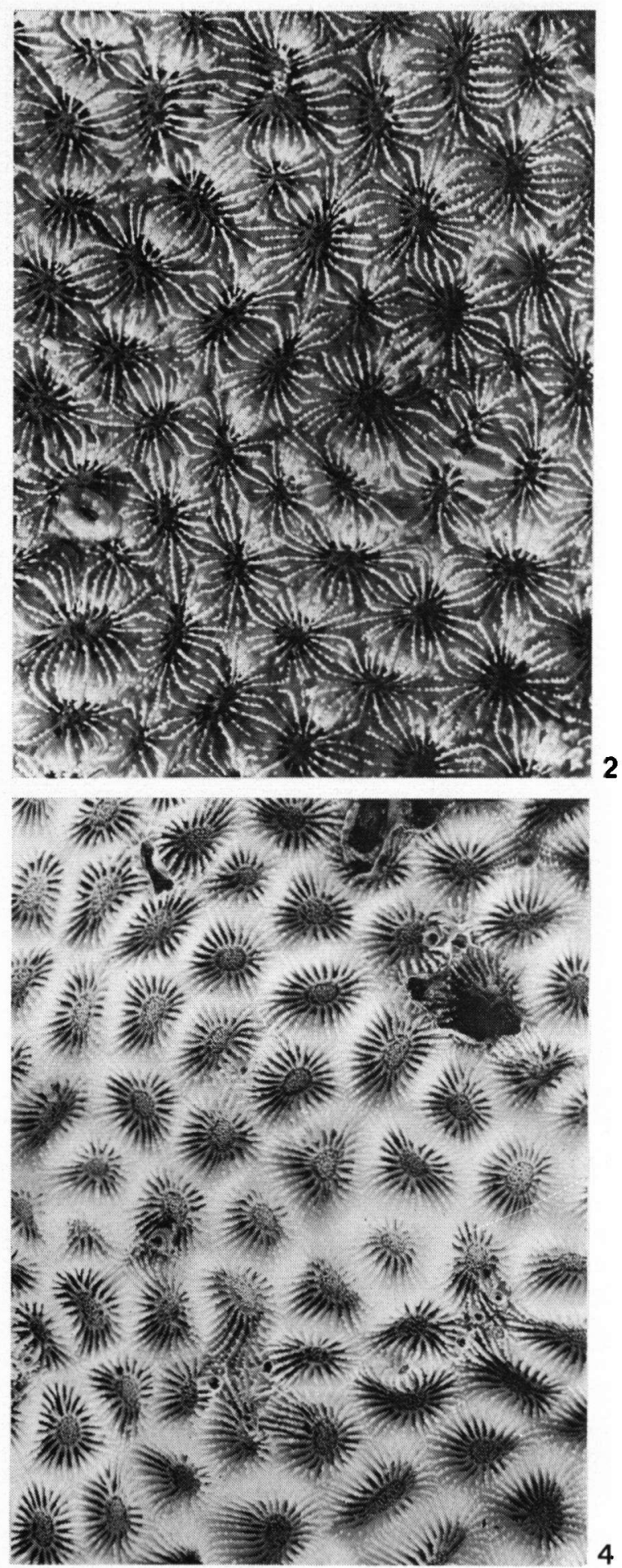

Fig. 2. Favites pentagona. Ecotype deformis from biotope 7 (depth $30 \mathrm{~m}$ ); ZMA Coel. 5840, $1.7 \times$.

Fig. 4. Favites chinensis. Ecotype complanata from biotope 4 (depth $10 \mathrm{~m}$ ); ZMA Coel. 5860, $1.7 \times$. 

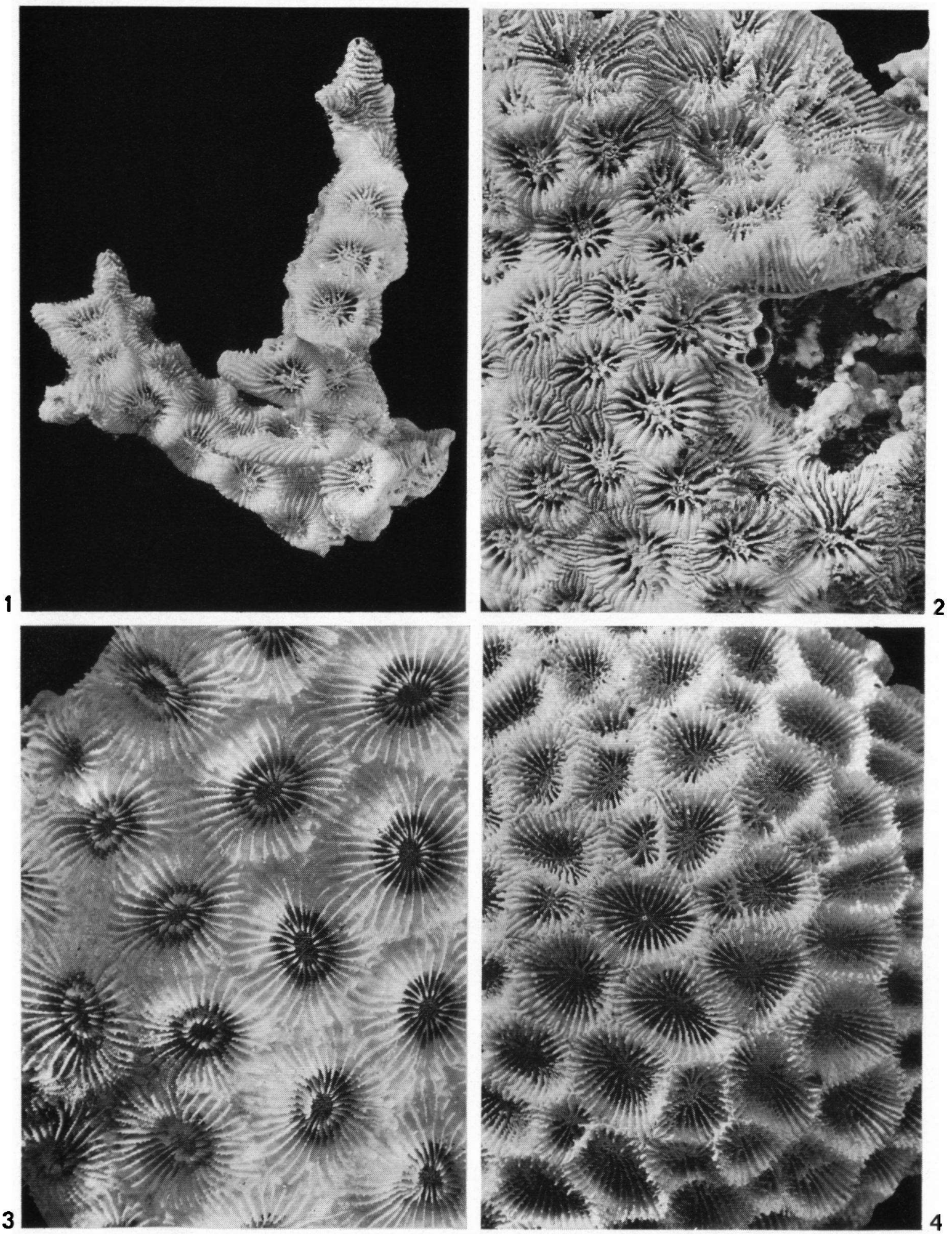

P1. VI.

Fig. 1. Favites rufa (holotype). Ecotype from biotope 6 (depth $5 \mathrm{~m}$ ); ZMA Coel. 5843, $1.3 \times$.

Fig. 3. Favites palauensis. Ecotype from biotope 7 (depth $30 \mathrm{~m}$ ); ZMA Coel. 5775, $1.7 \times$.

Fig. 2. Favites rufa (holotype). Ecotype from biotope 6 (depth $5 \mathrm{~m}$ ); ZMA Coel. 5843, $1.7 \times$.

Fig. 4. Favites acuticollis. Ecotype yamanarii from biotope 3 (depth $5 \mathrm{~m}$ ); ZMA Coel. 5779, $1.7 \times$. 

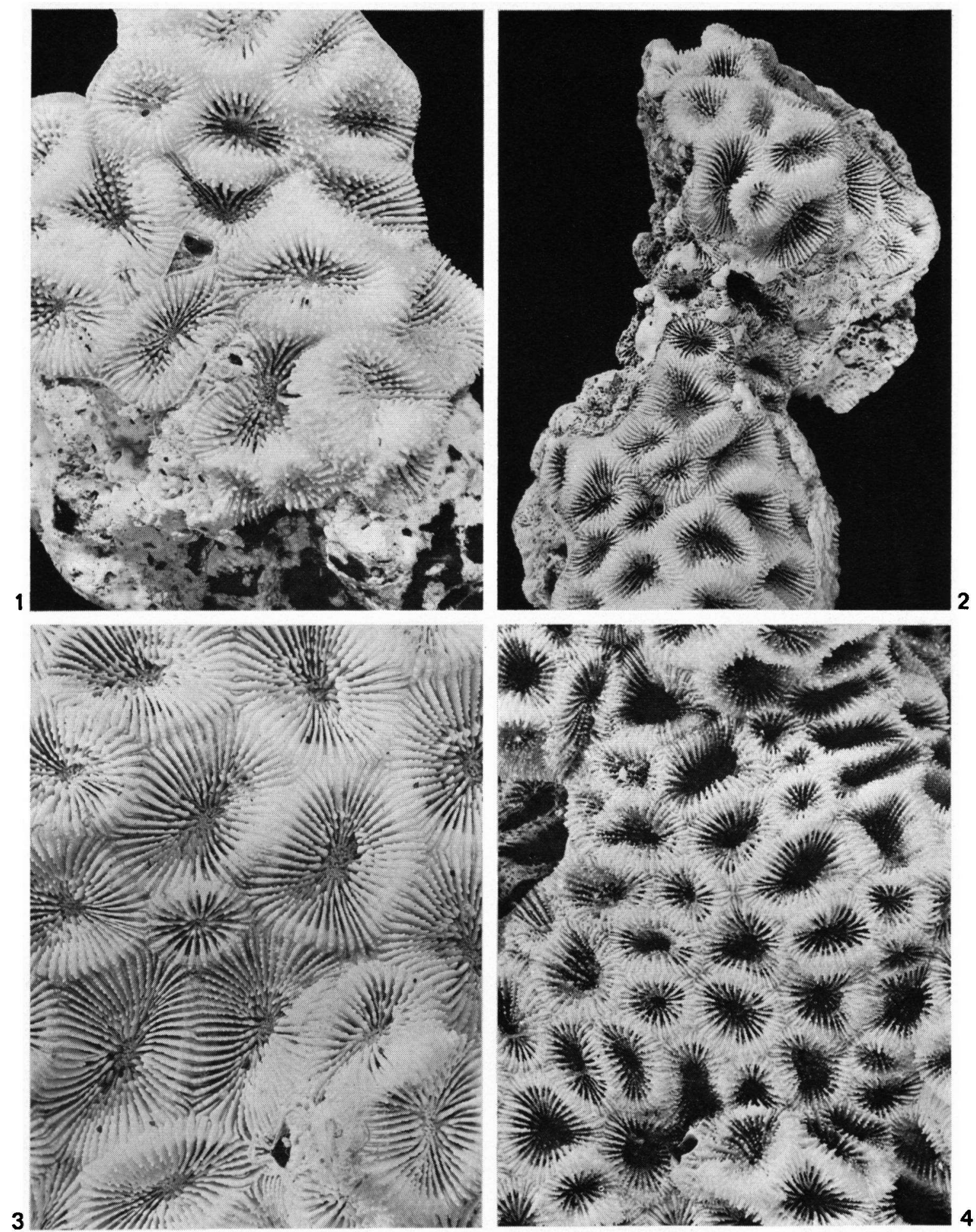

Pl. VII.

Fig. 1. Favites abdita. Ecotype halicora from biotope 2 (depth $15 \mathrm{~m}$ ); ZMA Coel. 5799, $1.7 \times$.

Fig. 3. Favites virens. Ecotype vasta from biotope 1 (depth $30 \mathrm{~m}$ ); ZMA Coel. 5788, $1.3 \times$.

Fig. 2. Favites abdita. Ecotype from biotope 3 (depth $10 \mathrm{~m}$ ); ZMA Coel. 5801, $1.7 \times$.

Fig. 4. Favites virens. Ecotype from biotope 6 (depth $10 \mathrm{~m}$ ); ZMA Coel. 5796, $1.3 \times$. 

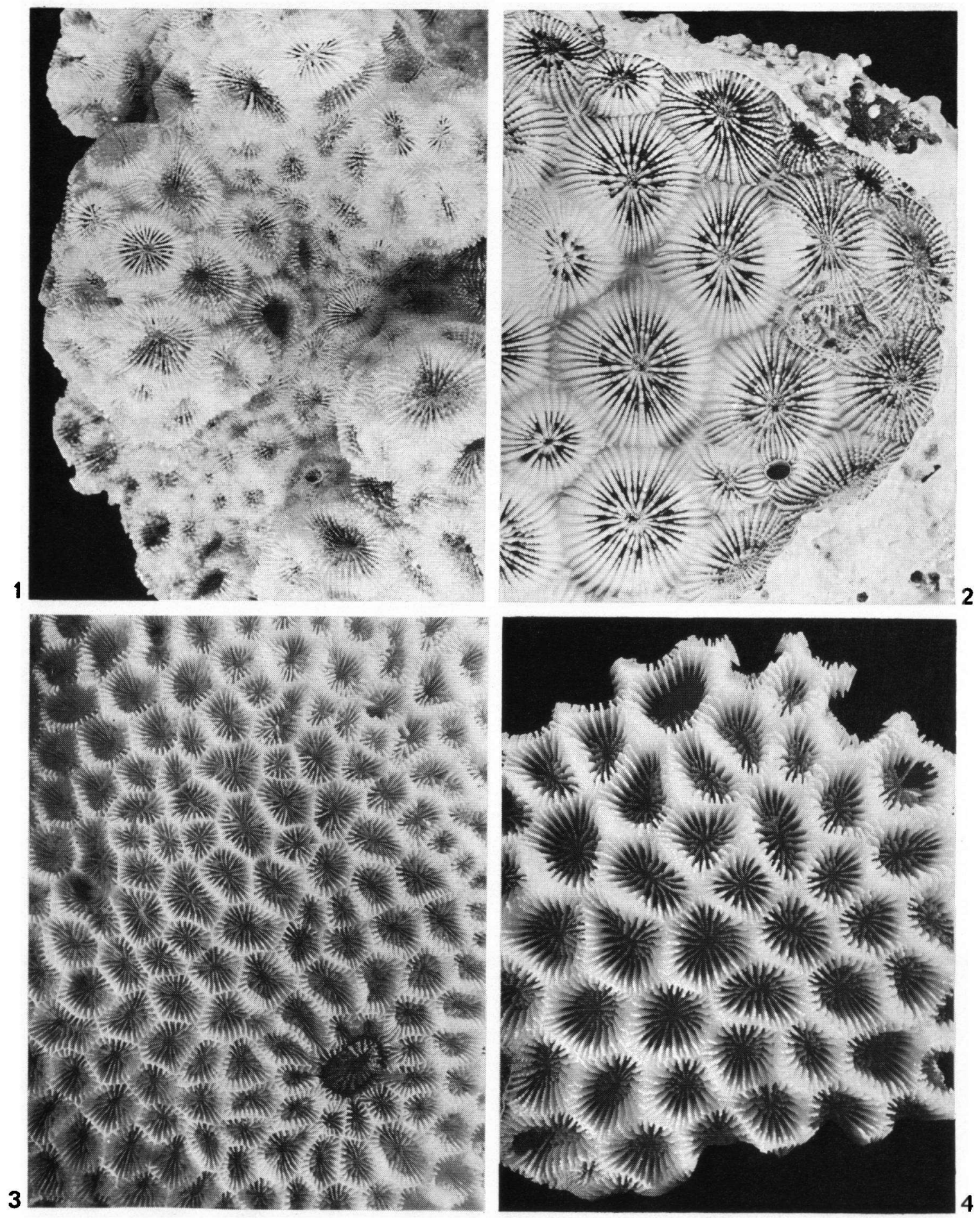

PI. VIII.

Fig. 1. Favites flexuosa. Ecotype from biotope 6 (depth $3 \mathrm{~m}$ ); ZMA Coel. 5787, $1.7 \times$.

Fig. 3. Goniastrea retiformis. Ecotype from biotope 1 (depth $10 \mathrm{~m}$ ); ZMA Coel. 5783, $1.9 \times$.
Fig. 2. Favites flexuosa. Ecotype from biotope 1 (depth $40 \mathrm{~m}$ ); ZMA Coel. 5782, $1.0 \times$.

Fig. 4. Goniastrea spectabilis. Ecotype from biotope 4 (depth $5 \mathrm{~m}$ ); ZMA Coel. 5877, $1.7 \times$. 

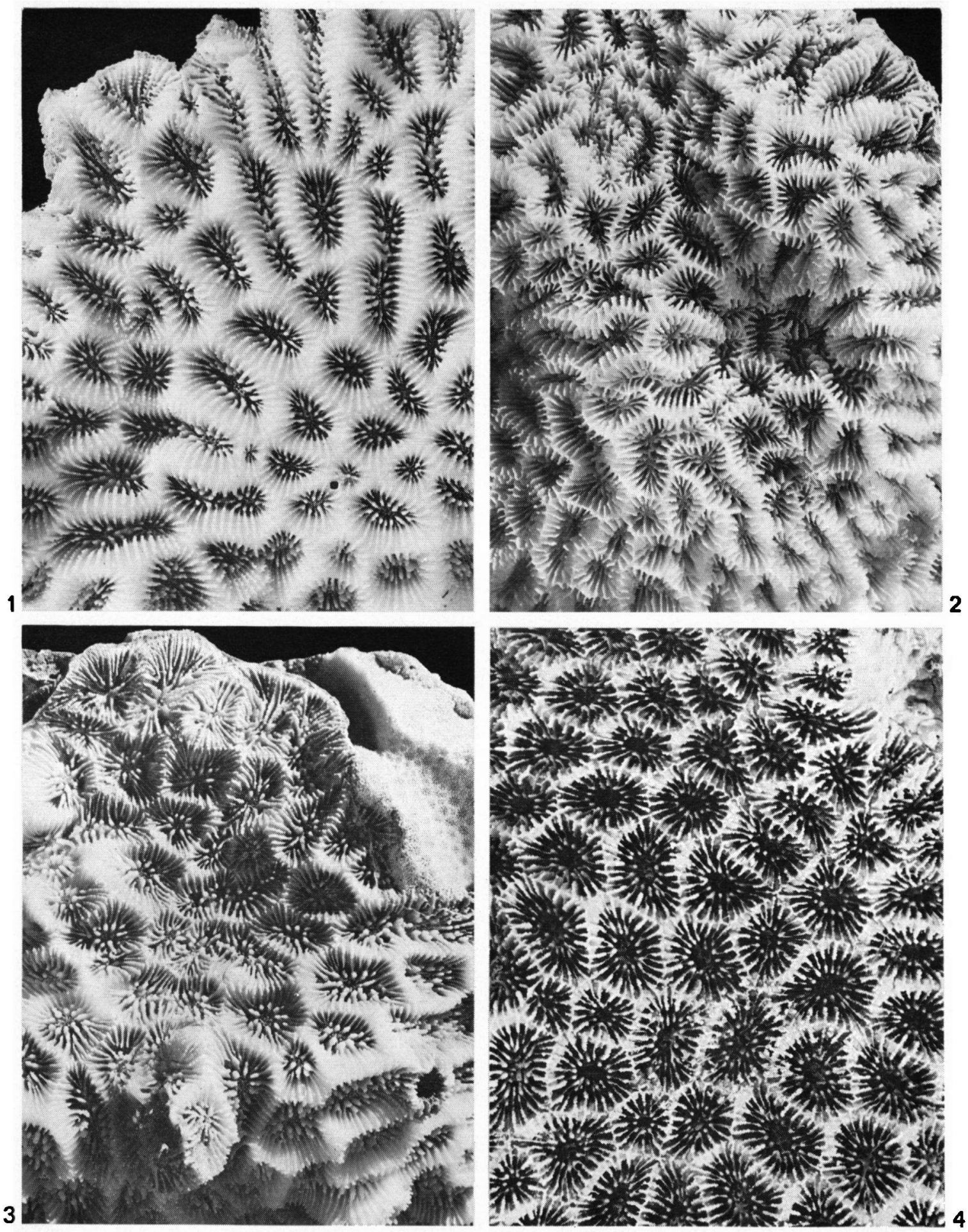

PI. IX.

Fig. 1. Goniastrea pectinata. Ecotype planulata from biotope 1 (depth $40 \mathrm{~m}$ ); ZMA Coel. 5885, $1.7 \times$.

Fig. 2. Goniastrea pectinata. Ecotype from biotope 6 (depth $10 \mathrm{~m}$ ); ZMA Coel. 5897, $1.7 \times$.

Fig. 3. Goniastrea pectinata. Ecotype from biotope 7 (depth $20 \mathrm{~m}$ ); ZMA Coel. 5900, $1.7 \times$.

Fig. 4. Goniastrea favulus. Ecotype from biotope 6 (depth $10 \mathrm{~m}$ ); ZMA Coel. 5906, $1.7 \times$. 

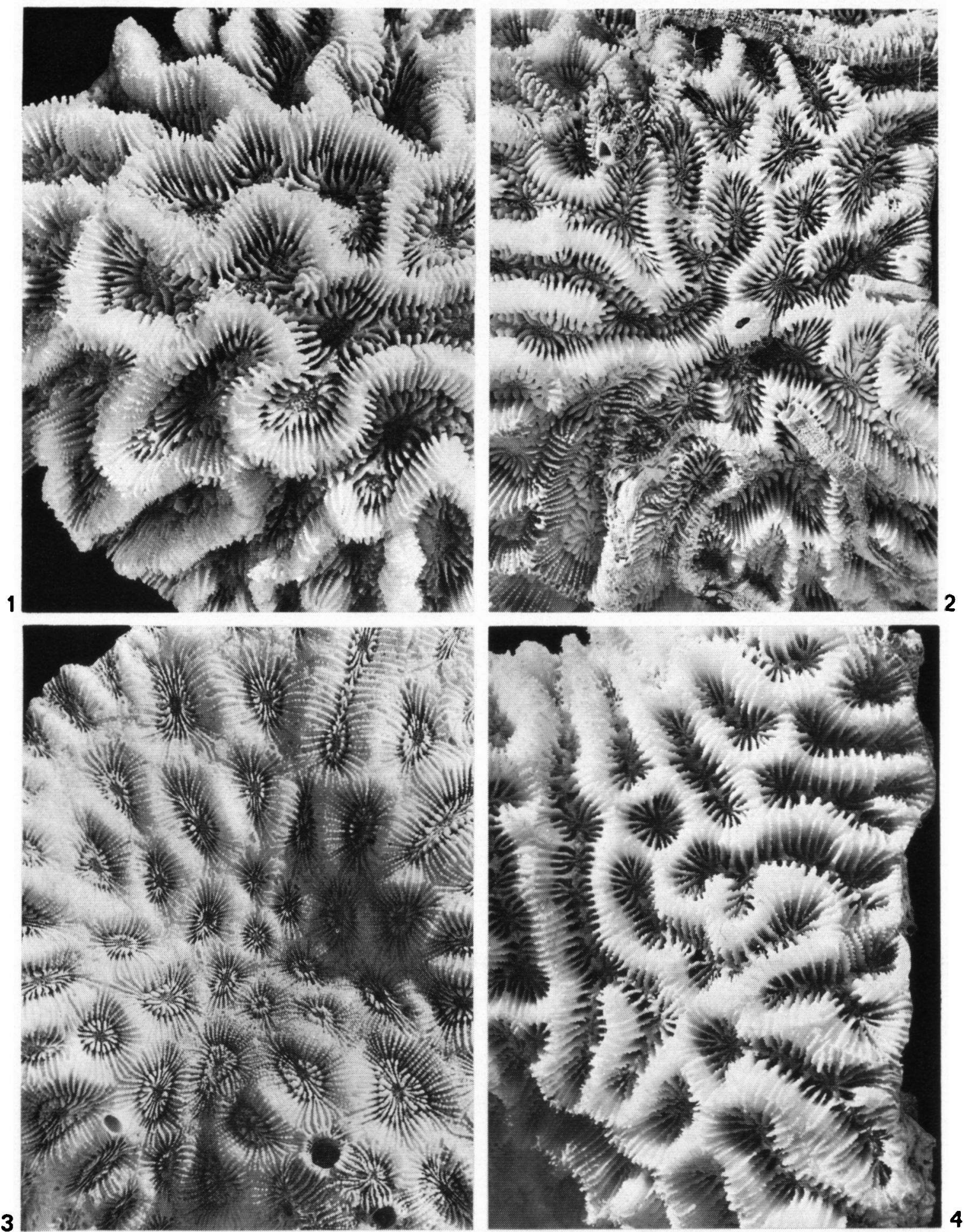

Pl. X.

Fig. 1. Goniastrea australensis. Ecotype benhami from biotope 4 (depth $8 \mathrm{~m}$ ); ZMA Coel. 5913, $1.7 \times$. Fig. 3. Goniastrea australensis. Ecotype equisepta from biotope 7 (depth $30 \mathrm{~m}$ ); ZMA Coel. 5928, $1.4 \times$.

Fig. 2. Goniastrea australensis. Ecotype from biotope 6 (depth $10 \mathrm{~m}$ ); ZMA Coel. 5922, $1.7 \times$.

Fig. 4. Platygyra lamellina. Ecotype from biotope 4 (depth $8 \mathrm{~m}$ ); ZMA Coel. 5972, $1.7 \times$. 

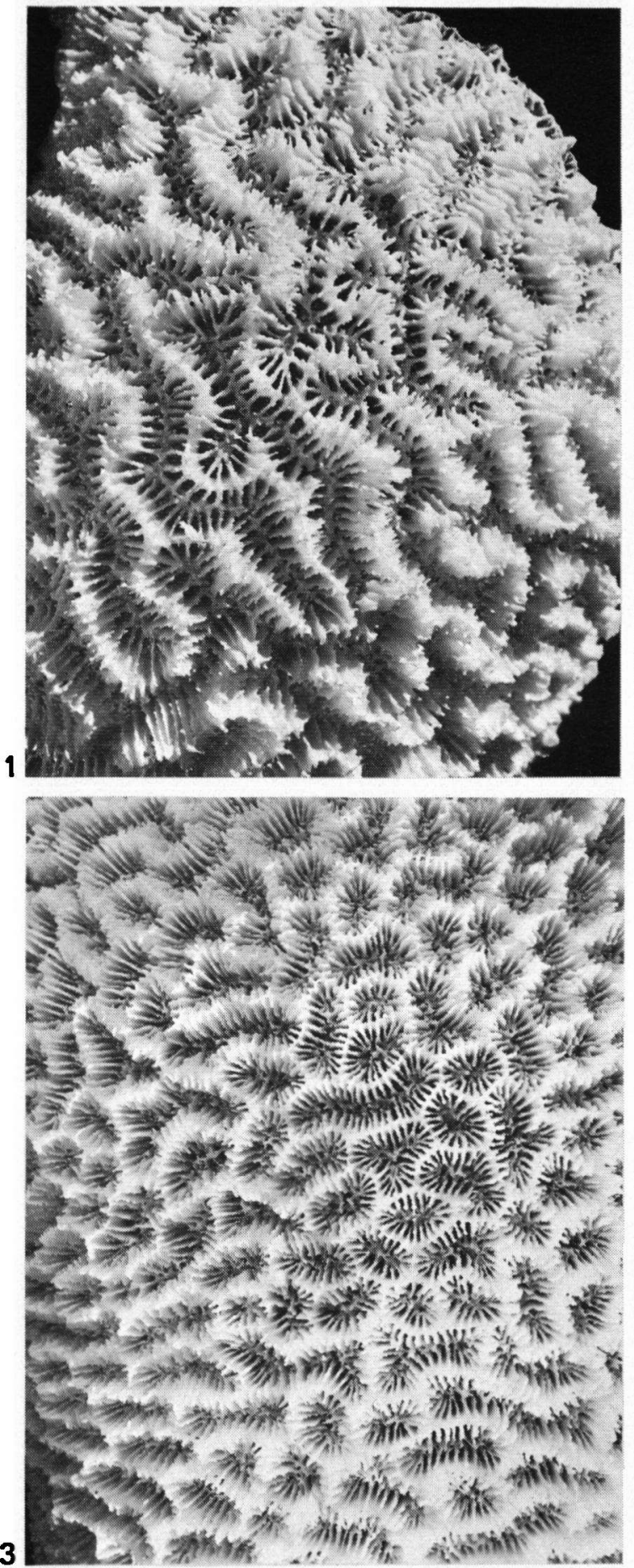

PI. XI.

Fig. 1. Platygyra daedalea. Ecotype from biotope 3 (depth $5 \mathrm{~m}$ ); ZMA Coel. 5947, $1.7 \times$.

Fig. 3. Platygyra sinensis. Ecotype from biotope 4 (depth $10 \mathrm{~m}$ ); ZMA Coel. 5980, $2.1 \times$.
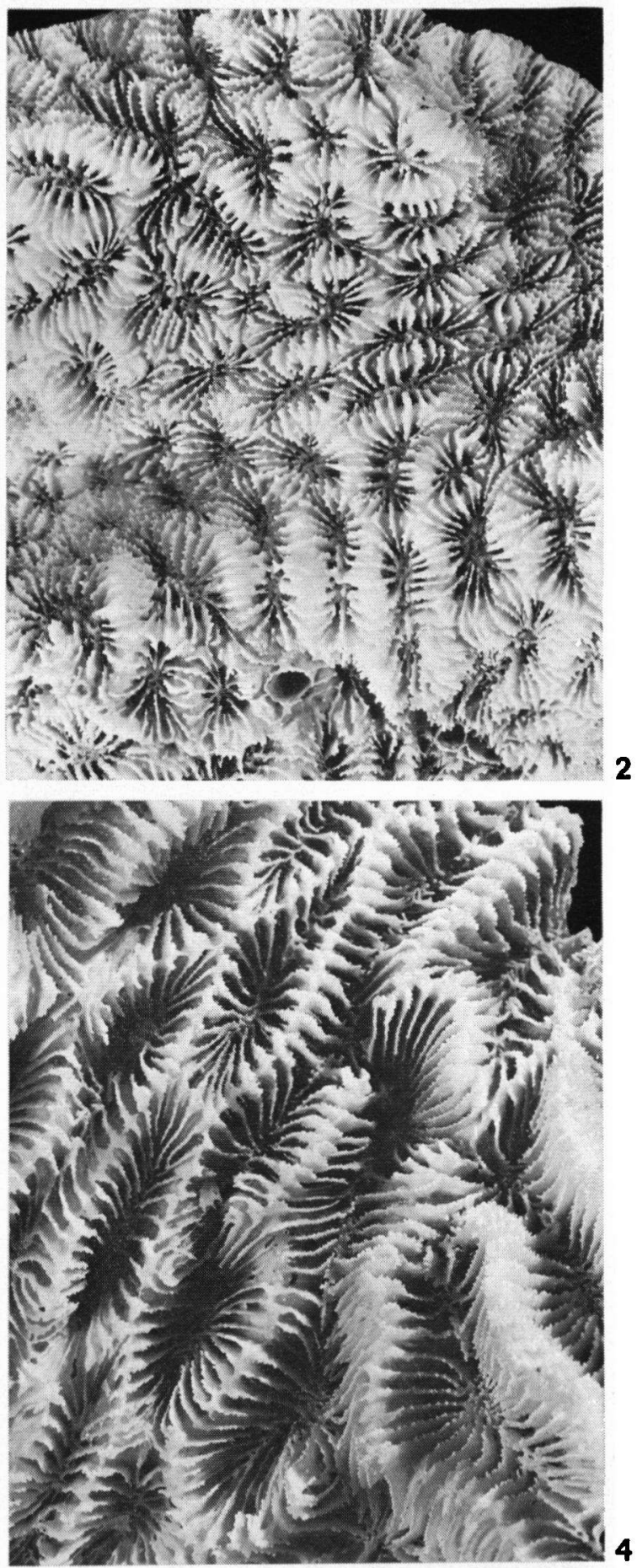

Fig. 2. Platygyra daedalea. Ecotype astreiformis from biotope 7 (depth $25 \mathrm{~m}$ ); ZMA Coel. 5960, $1.7 \times$.

Fig. 4. Oulophyllia crispa. Ecotype from biotope 2 (depth $20 \mathrm{~m}$ ); ZMA Coel. 6006, $1.7 \times$. 

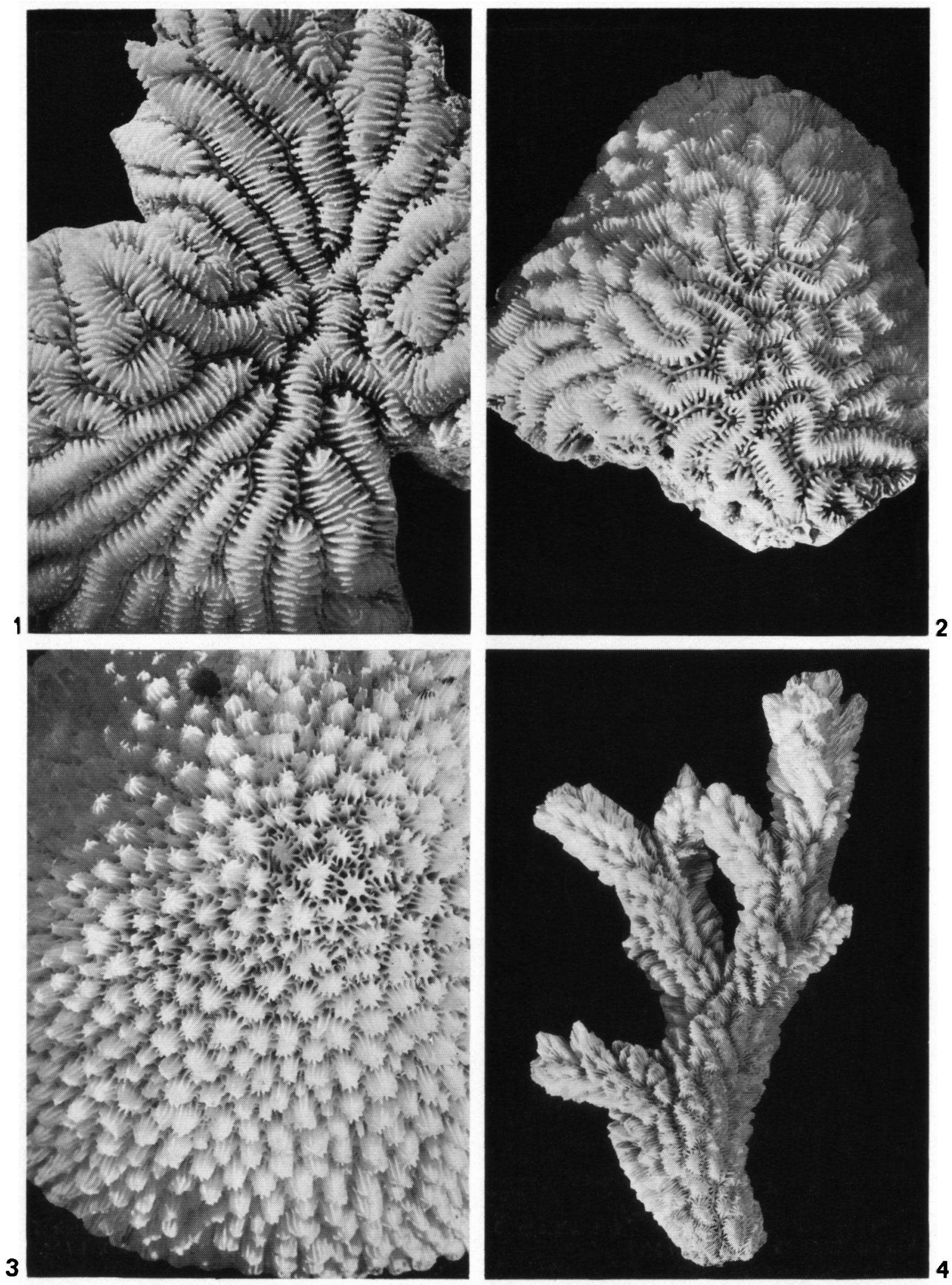

Pl. XII.

Fig. 1. Leptoria phrygia. Ecotype gracilis from biotope 1 (depth $25 \mathrm{~m}$ ); ZMA Coel. 6008, $2.3 \times$.

Fig. 3. Hydnophora microconos. Ecotype from biotope 3 (depth 5 m); ZMA Coel. 5992, $2.3 \times$.

Fig. 2. Leptoria phrygia. Ecotype from biotope 6 (depth $10 \mathrm{~m}$ ); ZMA Coel. 6009, $2.3 \times$.

Fig. 4. Hydnophora rigida. Ecotype from biotope 3 (depth 10 m); ZMA Coel 6004 , 1.4X.com $04 / 26 / 2023$ 10:01:24AM 

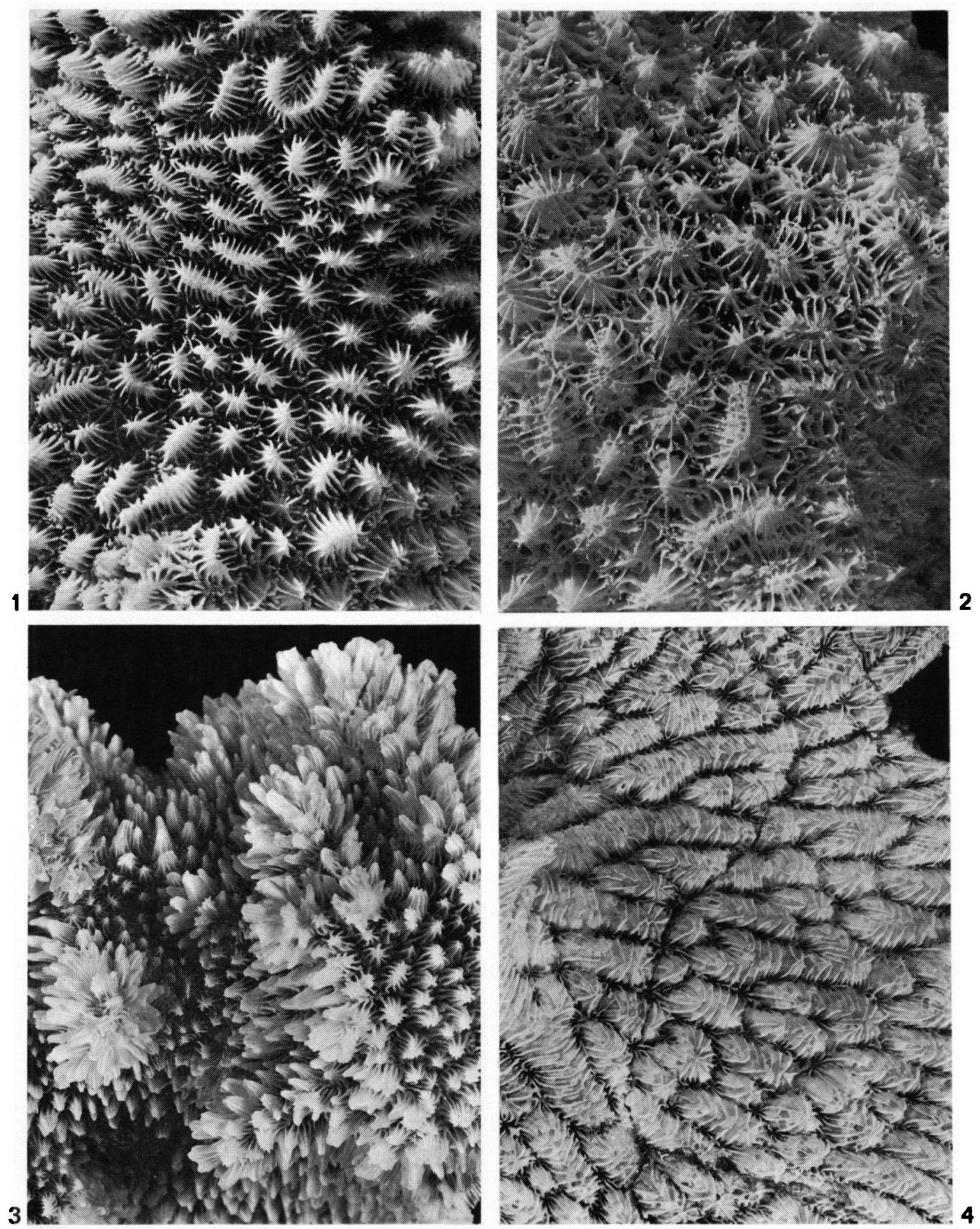

PI. XIII.

Fig. 1. Hydnophora exesa. Ecotype tenella from biotope 1 (depth $30 \mathrm{~m}$ ); ZMA Coel. 5993, $1.7 \times$.

Fig. 3. Hydnophora exesa. Ecotype gyrosa from biotope 5 (depth $10 \mathrm{~m}$ ); ZMA Coel. 5996, $1.7 \times$.

Fig. 2. Hydnophora exesa. Ecotype grandis from biotope 4 (depth $15 \mathrm{~m}$ ); ZMA Coel. 5995, $1.7 \times$.

Fig. 4. Hydnophora exesa. Ecotype maldivensis from biotope 7 (depth $35 \mathrm{~m}$ ); ZMA Coel. 5998, $1.3 \times$. 

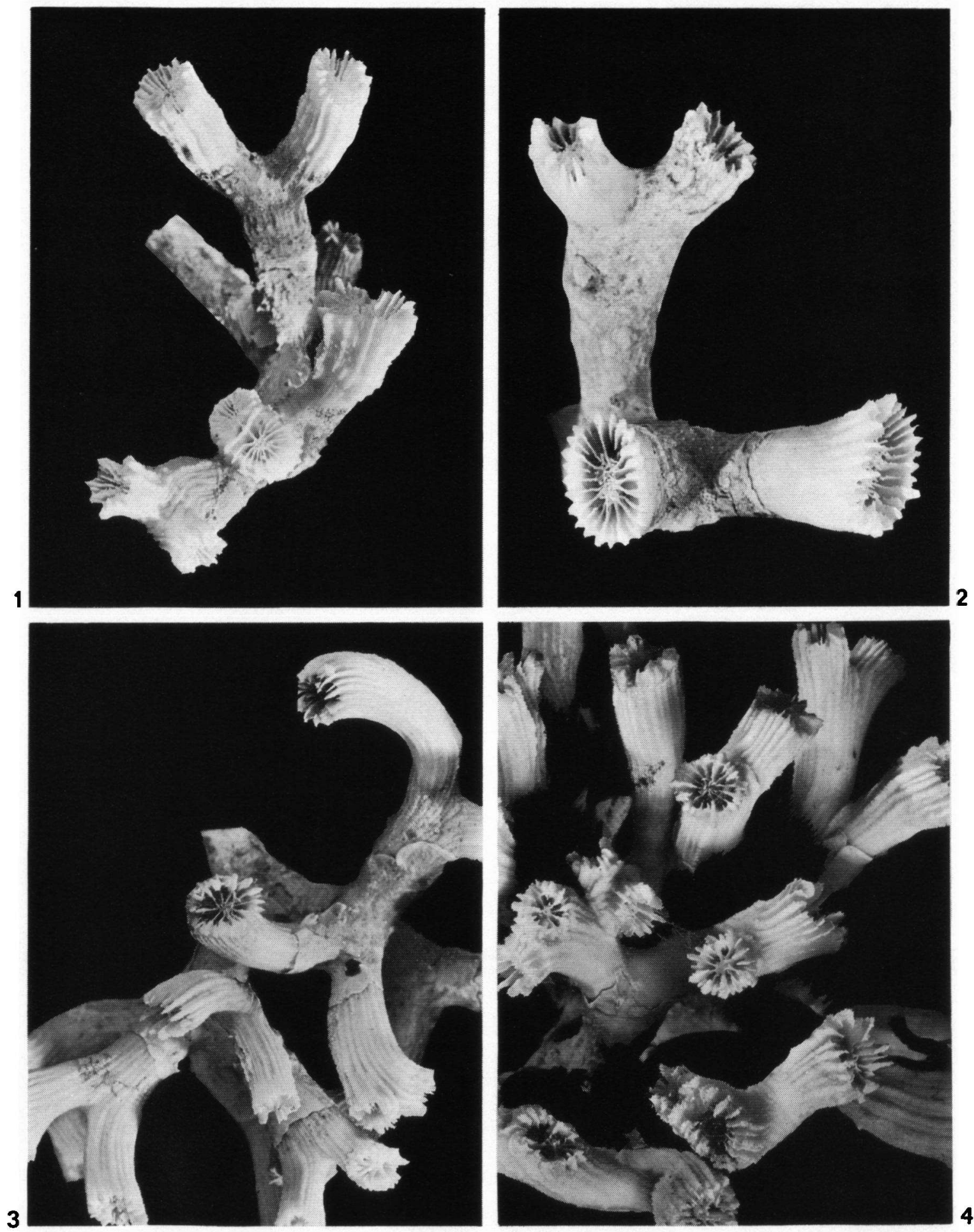

Pl. XIV.

Fig. 1. Caulastrea echinulata. Ecotype from biotope 7 (depth $5 \mathrm{~m}$ ); ZMA Coel. 5982, $1.3 \times$.

Fig. 3. Caulastrea curvata (holotype). Ecotype from biotope 7 (depth $5 \mathrm{~m}$ ); ZMA Coel. 5988, $1.3 \times$.

Fig. 2. Caulastrea furcata. Ecotype from biotope 7 (depth $30 \mathrm{~m}$ ); ZMA Coel. 5984, $2.1 \times$.

Fig. 4. Caulastrea curvata (paratype). Ecotype from biotope 7 (depth $5 \mathrm{~m}$ ); ZMA Coel. 5989, $1.3 \times$. 